Fernanda Regina Ribeiro Santos

\title{
Papel da Via Ciclo-Oxigenase na Inflamação e REABSORÇÃo ÓSSEA PERIAPICAL INDUZIDAS PELO \\ LIPOPOLISSACARÍDEO BACTERIANO
}

\author{
Tese apresentada à Faculdade de Odontologia de \\ Ribeirão Preto da Universidade de São Paulo, para \\ obtenção do Título de Doutor em Ciências. \\ Área de Concentração: Odontopediatria.
}

Orientador: Dr. Francisco W. Garcia de Paula e Silva 
Autorizo a reprodução e divulgação total ou parcial deste trabalho, por qualquer meio convencional ou eletrônico, para fins de estudo e pesquisa, desde que citada a fonte.

\section{FICHA CATALOGRÁFICA}

Santos, Fernanda Regina Ribeiro

Papel da via ciclo-oxigenase na inflamação e reabsorção óssea periapical induzidas pelo lipopolissacarídeo bacteriano. Ribeirão Preto, 2015.

157p. : il. ; $30 \mathrm{~cm}$

Tese de Doutorado apresentada à Faculdade de Odontologia de Ribeirão Preto/USP - Área de Concentração: Odontopediatria.

Orientador: Paula-Silva, Francisco Wanderley Garcia de

1. Lipopolissacarídeo bacteriano 2. Ciclo-oxigenase

3. Osteoclastogênese 4. Reabsorção Óssea 5.Indometacina 6.

Celecoxibe 7. Inflamação 
Santos, fRr. Papel da Via Ciclo-Oxigenase na Inflamação e Reabsorção Óssea PERIAPICAL IndUZIDAS PELO LIPOPOLISSACARÍDEO BACTERIANO

Tese apresentada à Faculdade de Odontologia de Ribeirão Preto da Universidade de São Paulo, para obtenção do Título de Doutor em Ciências.

Área de Concentração: Odontopediatria.

Data da defesa:

\section{Banca Examinadora}

Prof. Dr.

Instituição:

Julgamento: Assinatura:

Prof. Dr.

Instituição:

Julgamento: Assinatura:

Prof. Dr.

Instituição:

Julgamento: Assinatura:

Prof. Dr.

Instituição:

Julgamento:

Assinatura:

Prof. Dr.

Instituição:

Julgamento: Assinatura: 



\section{Dados CURRICULARES}

\section{Fernanda Regina Ribeiro Santos}

Nascimento 8 de junho de 1984 - Maceió/AL

Filiação Carlos Henrique Bezerra Santos

Neusa Ribeiro Santos

2003-2008

Curso de Graduação

Faculdade de Odontologia da Universidade

Federal de Alagoas - FOUFAL/UFAL

2009-2011 Curso de Especialização em Odontopediatria

Associação Odontológica de Ribeirão Preto - AORP

2009-2012 Curso de Pós-Graduação em Odontopediatria, nível de Mestrado na Faculdade de Odontologia de Ribeirão Preto da Universidade de São Paulo - FORP/USP - Dissertação intitulada "Ciclo-oxigenase-2 modula in vivo a expressão de marcadores da osteoclastogênese e genes envolvidos no metabolismo ósseo em resposta ao lipopolissacarídeo bacteriano".

2012-2015 Curso de Pós-Graduação em Odontopediatria, nível de Doutorado na Faculdade de Odontologia de Ribeirão Preto da Universidade de São Paulo - FORP/USP

2014 Docente na disciplina de Odontopediatria da Universidade de Pernambuco - UPE 

Trabalho realizado com apoio financeiro do Programa de Auxílio à Pesquisa Jovem Pesquisador (processo 2010/17611-4) e Bolsa de Doutorado (processo 2012/08421-2), concedidos pela Fundação de Amparo à Pesquisa do Estado de São Paulo (FAPESP). 



\section{DEDICATÓRIA}

A Deus, por existir e viver...pela oportunidade de cumprir minha missão nesta passagem, de uma maneira tranquila. Por me fazer enxergar o mundo com a mesma essência da criança que existe em mim. Por guiar meus passos. Por colocar anjos de luz em minha vida. Por me fazer acreditar em mim. Minha gratidão diária em forma de prece.

Aos meus queridos pais, Neusa Ribeiro Santos e Carlos Henrique Bezerra Santos pelo amor, dedicação, apoio e compreensão que sempre encontrei em vocês e, principalmente, pela segurança transmitida nos momentos de dificuldade e insegurança. Por todos os "Bom dia com alegria" e "Boa tarde com felicidade" durante esses seis anos, que faziam do meu dia muito mais feliz. Por não medir esforços a cada feriado e ter o carinho de sempre estar presente em minha vida, em todos os sentidos. Por nada ter mudado. Aliás, ficamos muito mais unidos! Por sempre confiarem em mim e me apoiarem em todas as minhas escolhas. Obrigada por sempre investirem em minha educação. Vocês são os grandes responsáveis por esta conquista e merecedores de tamanha alegria. Todo meu amor a vocês.

A minha irmã Lenda Vanessa de Lima Pinheiro, muitas vezes minha mãe e muitas vezes minha filha! Você pra mim é sinônimo de garra, força, persistência e perseverança. Sempre estaremos juntas!

A minha avó Amélia Bezerra Santos (in memoriam), por sua presença e amor. Por nossa sintonia eterna! 



\section{Agradecimento Especial}

Ao meu orientador Prof. Dr. Francisco Wanderley Garcia de Paula e Silva, presente nesses seis anos de convivência diária. Meu grande exemplo de mestre, com toda sua disciplina e sabedoria. E mais que isso, exemplo de carăter! Obrigada por me apresentar ao mundo acadêmico e todos os seus contextos. Ao longo dessa caminhada, agradeço cada vez mais a Deus por tê-lo colocado em meu caminho, desde o princípio. Hoje, percebo o quanto foi importante para minha formação de Mestre e Pesquisadora, cada gesto, atitude e palavras vindas de você. Muito obrigada por fazer parte desse momento único e tão especial de minha vida.

"Ensinar é um dom, mas mais que ensinar é cativar os corações de seus seguidores, para que além de seus ensinamentos permaneça na memória a imagem de um mestre. O verdadeiro mestre é aquele que transcende as barreiras do tempo e espaço e mantém vivos na mente de seus discípulos a sua sabedoria, seus princípios de vida e suas idéias, para toda a eternidade." 



\section{Agradecimentos}

Ao Prof.Dr.Paulo Nelson Filho, por ter me apresentado a verdadeira Odontopediatria. Pela brilhante maneira em transmitir seus ensinamentos, servindo de exemplo durante toda minha trajetória na FORP. Pela acolhida e confiança. Professor, muito obrigada por todo apoio, desde o início!

À Profa. Dra . Maria Cristina Borsatto, pelos ensinamentos que vão além do mundo científico. Pelos abraços apertados, palavras de carinho, pelas melhores gargalhadas, pelos "programas de índio", por todos os conselhos sempre tão valiosos, por curar minha rinite com a Acupuntura! Cris, como eu gosto de você! Obrigada por fazer parte da minha vida (e sempre será assim!) e ser essa pessoa tão especial.

A Profa.Dra. Andiara de Rossi Daldegan, por muitas vezes ter servido de instrumento para acalmar meu coração e me fazer encontrar a confiança que precisei. Andi, iá tive a oportunidade de muitas vezes falar de sua importância em meu caminho. Carinho e afinidade não se explicam! Hoje, tento colocar em prática com meus alunos o que aprendi te observando. O meu exemplo mais doce e sereno!

Aos professores da Universidade Federal de Alagoas/UFAL, Amaro Carlos Júnior, Dulce Maria Santos Simões e Edgar Norões Rodrigues da Mata, os grandes responsáveis pelo início dessa caminhada. Meus mestres inspiradores da graduação, hoje, amigos queridos. Minha admiração e carinho sempre serão eternos, muito obrigada!

Ao amigo Igor Ferreira Bassi Petean, um anjo que Deus colocou em minha vida! A amizade mais sincera! Obrigada por sempre estar presente, por muitas vezes ser a força que precisei. Por toda ajuda desde o Mestrado, pelos melhores sorrisos, pelas várias conversas através do olhar. Te amo, filhote! 
Às queridas amigas, Marilia Pacífico Lucisano, Katharina Morant, Kêssia Suênia Fidelis de Mesquita Guimarães, Danielle Luca Longo, Patrícia Garani Fernandes, Nilza Letícia e Francine Lorencetti da Silva. Obrigada pela grande ajuda que vocês me ofereceram, me apoiando e auxiliando na execução da parte experimental deste estudo. Não tenho palavras para agradecer a boa vontade e disponibilidade prestada. Mas agradeço principalmente a linda amizade que construímos. Nossas conversas e abraços apertados, sempre renovando minhas energias.

Às queridas amigas-irmãs, lliana Ferraz Sabbatini e Soraia Barbosa Bernardes Ferreira. Minhas futuras comadres! Nosso encontro já havia acontecido há muito tempo. Nenhuma distância será capaz de diminuir toda sintonia e carinho que existe entre nós. Obrigada por tornarem minha vida mais leve! Amo vocês!

Aos que entraram em meu caminho de maneira tão intensa e me incentivaram com as palavras mais doces, Stefânia J. Ferreira e Antonio Augusto de Athayde Filho. Stezinha, você foi fundamental na conclusão desse trabalho. Muito obrigada por ser esse anjo em minha vida e me oferecer essa amizade tão sincera. Estaremos sempre juntas, minha amiga!! Guguinha, após 24 anos...a vida nos colocou mais uma vez diante do outro. E como estou feliz com esse reencontro! Obrigada por me incentivar e saber que posso contar com seu apoio. Você sempre foi especial pra mim, desde os 6 anos de idade!

As minhas tias Nena e Yara, por todo amor recebido no momento que mais precisei. Não tenho palavras para agradecer todos os ensinamentos e carinho que sempre recebi. Agradeço também a minha prima, Déa, minha grande incentivadora nos momentos de desânimo. A participação de vocês foi essencial para conclusão desse momento. Muito obrigada, de coração! Amo vocês!

A minha famillia paterna de Recife, tia Silvinha, Leãozinho, Juju e Lukinha. Sou muito feliz por ter vocês, é tanto amor... Muito obrigada por todos os momentos em que estamos juntos, é sempre uma alegria poder estar perto dessa familia, que também é minha. Tia Silvinha, eu sempre vou me inspirar em você! 


\section{Meus Áradecimentos}

À Faculdade de Odontologia de Ribeirão Preto da Universidade de São Paulo, na pessoa do atual diretor Prof.Dr.Valdemar Mallet da Rocha Barros.

À Coordenação do Curso de Pós-Graduação em Odontopediatria da Faculdade de Odontologia de Ribeirão Preto da Universidade de São Paulo, na pessoa da Profa.Dra. Léa Assed Bezerra da Silva e da Vice-CoordenadorA Profa.Dra .Raquel Assed Bezerra Segato.

Aos Professores do Departamento de Clínica Infantil, Odontologia Preventiva e Social da Faculdade de Odontologia de Ribeirão Preto da Universidade de São Paulo Profa.Dra Léa Assed Bezerra da Silva, Prof ${ }^{a}$.Dra .Aldevina Campos Freitas, Prof.Dr. Paulo Nelson Filho, Profá.Dra.Alexandra Mussolino de Queiroz, Prof.Dr.Mărio Roberto Leonardo, Fabrício Kitazono de Carvalho, Profa.Dra.Kranya Victória Díaz Serrano, Prof ${ }^{a}$.Dra $r^{a}$.Maria Cristina Borsatto, Prof ${ }^{a}$.Dra .Raquel Assed Bezerra da Silva, Prof ${ }^{a}$.Dra Andiara $^{a}$ De Rossi, Profa. Dra. Mírian Aiko Nakane Matsumoto, Profa. Dra Maria Bernadete Sasso Stuani, Prof.Dr.José Tarcísio Lima Ferreira, Prof.Dr. Adilson Thomazinho, Prof ${ }^{\text {.Dra }}$.Maria da Conceição Pereira Saraiva e Prof.Dr. Fábio Lourenço Romano, pela agradável convivência, pelas conversas atenciosas e pelos valiosos ensinamentos.

A Profá.Drá.Lúcia Helena Faccioli e membros do Laboratório de Inflamação e Imunologia das Parasitoses e ao Prof. Dr. Sérgio Akira Uyemura e membros do Laboratório de Bioquímica Clínica, ambos da Faculdade de Ciencias Farmacêuticas da Universidade de São Paulo, por disponibilizarem o espaço físico e os equipamentos sob sua responsabilidade para utilização nesta pesquisa.

Aos professores da banca, pela atenção dispensada na leitura desta dissertação. 
Às amigas queridas da minha turma de Pós-Gradução, Gabriela Santin, Daniela Silva Barroso de Oliveira, Marilia Rodrigues Moreira, Lídia Hidalgo e Késsia Suênia Fidelis de Mesquita, por fazerem nossa turma ser tão especial. Agradeço pelo convívio, companheirismo, pelas risadas e acima de tudo, pela amizade.

Aos amigos Geyson Galo, Pedro Leão e Daniella Cristina Borges, pelo carinho e amizade sincera. Vocês tornaram meus dias em Ribeirão Preto muito mais felizes!

Aos colegas e amigas da Pós-Graduação, Camila Scatena, Sofia Sampaio, Cỉntia Guimarães de Almeida, Carolina Maschietto, Gabriela Flores, Maya Fernanda Arnez, Juliana Arid, Rodrigo Alexandre Valério, Talitha de Siqueira Mellara, Carolina Paes Torres Mantovani, Cristhiane Ristum Bagatin Rossi, Jaciara Miranda Gomes da Silva, Cristina Bueno Brandão, Marcela Cristina Damião Andrucioli, Ana Zilda Nazar Bergamo, Marta Maria Martins Giamatei Contente, Milena Silva Campos, Cristhiane Ristum Bagatin Rossi, Rodrigo Galo, Alessandra Marques Corrêa Afonso, Priscilla Coutinho Romualdo, Larissa Nogueira Soares Ribeiro, Denise de Souza Matos, Danielly Cunha Araújo Ferreira, Ana Caroline Fumes, Mariana Alencar Nemezio, Karina Alessandra Michelão Grecca Pierone, Bārbara Jarreta, Driely Barreiros de Oliveira, Érika Calvano Kuchler, Mariana Daltoé, Marina Vilela, Elaine Pingueiro, Leonardo Matos, Claudia Carpio, Talita Prates, Patrícia Monteiro, Mariele Andrade e Silvana Aparecida Fernandes Polizeli pela agradável convivência, e valiosos momentos compartilhados.

Aos funcionários do laboratório, Marco Antonio dos Santos, Nilza Letícia Magalhães e Fátima Aparecida Jacinto Daniel. Todos os momentos em que passei no laboratório foram mais felizes por ter a companhia de vocês. Serei eternamente grata aos ensinamentos, conselhos, abraços e massagens da Fafá! Estarão para sempre em meu coração! Agradeço também a Renata Zanão e Tatiana Goudromihos, por toda a ajuda disponibilizada na parte experimental desse trabalho e por tornarem esses momentos mais alegres. 
À Micheli Cristina Leite Rovanholo, pelo apoio durante esses anos. Mi, obrigada pelo carinho e por sempre me ajudar!

Aos funcionários do Departamento de Clínica Infantil, Odontologia Preventiva e Social, Da Fundação Odontológica de Ribeirão Preto (FUNORP) e Da Clínica de Pacientes Especiais da Faculdade de Odontologia de Ribeirão Preto da Universidade de São Paulo, Filomena Leli Placciti, Matheus Morelli Zanela, Vera do Nascimento Scandelai, Fatima Aparecida Rizoli, Rosemary Alves, Renata Cristina Rosa, Benedita Viana Rodrigues e Renata Aparecida Fernandes, pela alegre convivência.

Aos funcionários do Biotério I, Antônio Sérgio Aparecido Mesca, Antônio Massaro e Aline Aparecida Ferraresi Tiballi, pela ajuda e disponibilidade durante a realização dos procedimentos experimentais em camundongos.

Aos funcionários da Seção de Pós-Graduação da Faculdade de Odontologia de Ribeirão Preto da Universidade de São Paulo, Isabel Cristina Galino Sola, Regiane Cristina Moi Sacilloto e Mary Possani, pela atenção e por estarem sempre à disposição. Rê, sua gargal hada é a melhor do mundo!

Aos amigos de trabalho da Universidade de Pernambuco - UPE, Arine Lyra, Eduardo Duarte, Eudes Lorena, Lucio Flāvio Azevedo, Marconi Maciel, Marianne Carvalho, Paulo Reis, Luiz Gutenberg, Tereza Correia, Stefânia J. Ferreira, Leonardo Carnut e Fábio Andrew, pela acolhida, disponibilidade e amizade. Obrigada por sempre estarem dispostos a me ajudar. Tenho muito orgulho em fazer parte desta equipe!

A todos que contribuíram direta ou indiretamente para concretização deste trabalho. Muito obrigada!

À CAPES (Coordenação de Aperfeiçoamento de Pessoal de Nível Superior) e à FAPESP (Fundação de Amparo à Pesquisa do Estado de São Paulo), pelo suporte financeiro concedido. 



\section{RESUMO}

SANTOS frR. Papel da Via Ciclo-Oxigenase na Inflamação e Reabsorção Óssea Periapical Induzidas pelo Lipopolissacarídeo Bacteriano [TESE]. RibeirÃo PRETO: Universidade de SÃo PaUlo, FACULdAde de Odontologia de Ribeirão Preto, 2015. 157p.

Durante o processo inflamatório, mediadores são liberados com o objetivo de estimular a resposta imune celular e humoral. Através da ação da enzima ciclo-oxigenase ocorrem modificações estruturais na cadeia do ácido araquidônico levando a síntese de prostaglandinas, potenciais responsáveis pela regulação do metabolismo ósseo durante eventos inflamatórios. Dessa maneira, o objetivo deste estudo foi avaliar o papel da enzima ciclo-oxigenase na inflamação pulpar e reabsorção óssea periapical, após inoculação de lipopolissacarídeo bacteriano (LPS) na câmara pulpar de molares de camundongos. Foram utilizados 144 camundongos C57BL/6, nos quais foram inoculados na câmara pulpar dos primeiros molares uma solução contendo LPS de $E$. Coli $(1,0 \mathrm{mg} / \mathrm{ml})$. Decorridos os períodos experimentais de 7, 14, 21 e 28 dias, os animais foram submetidos à eutanásia e os blocos contendo dente e osso foram removidos para processamento histotécnico e extração de RNA. Os efeitos do bloqueio farmacológico com indometacina (inibidor não seletivo de COX) e celecoxibe (inibidor seletivo de COX-2) na expressão de RANK, RANKL, OPG e outros genes envolvidos no metabolismo ósseo foram investigados. Cortes histológicos foram realizados, corados por hematoxilina e eosina, marcados para imunohistoquímica para COX-2 e analisados por microscopia de luz convencional. O recrutamento de células inflamatórias mononucleares e polimorfonucleares para o tecido pulpar foi avaliado em três regiões da polpa radicular (cervical, média e apical). Em seguida, foi realizada a avaliação da expressão gênica por meio de transcrição reversa e reação da polimerase em cadeia em tempo real (qRT-PCR), utilizando o sistema TaqMan $^{\circledR}$ e por meio de um ensaio de PCR Array (Osteogenesis RT2 Profiler PCR Array). A inoculação de LPS na câmara pulpar de molares de camundongos foi capaz de induzir a expressão do gene Ptgs2, responsável pela codificação da enzima COX-2, envolvida no metabolismo do ácido araquidônico, assim como dos receptores para PGE $_{2}$ Ptger1, Ptger3 e Ptger4. Concomitantemente houve a indução da expressão dos genes Tnfrsf11a, Tnfsf11 e Tnfrsf11b, responsáveis pela codificação dos moduladores da osteoclastogênese RANK, RANKL e OPG, respectivamente. Indometacina e Celecoxibe, inibidores não-seletivo e seletivo de COX-2, respectivamente, modularam diferencialmente a expressão dos genes Tnfrsf11a, Tnfsf11 e Tnfrsf11b. Histologicamente, os medicamentos utilizados não inibiram o desenvolvimento da reabsorção óssea na região periapical. Durante o período de 28 dias, em animais em que o LPS foi inoculado e administrado Indometacina, foi observado um aumento significante da lesão periapical. Alguns genes relacionados ao anabolismo ósseo tiveram sua expressão aumentada nos períodos iniciais de resposta à inoculação de LPS na câmara pulpar, com a inibição da via ciclo-oxigenase, como: Bmpr1b, Col10a1, Col14a1, Col17a1, Ahsg e Msx1. Tendo em vista que Celecoxibe e Indometacina modularam diferencialmente a expressão de genes envolvidos no metabolismo ósseo após inoculação de LPS, parece existir um papel distinto para COX-1 e COX-2 no desenvolvimento da lesão periapical.

Palavras-chave: lipopolissacarídeo bacteriano, ciclooxigenase, osteoclastogênese, reabsorção óssea, Indometacina, Celecoxibe, inflamação. 

SANTOS FRR. Role Of Cyclooxygenase in Inflammation and Periapical Bone RESORPTION INDUCED BY BACTERIAL LIPOPOLYSSACHARIDE [THESES]. RIBEIRÃO PRETO:

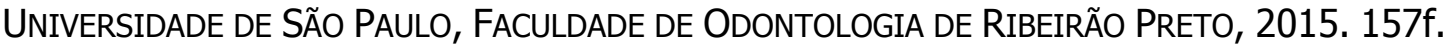

During the inflammatory process, mediators are released in order to stimulate cellular and humoral immune response. Through the action of the enzyme cyclooxygenase structural changes occur in the chain of arachidonic acid leading to prostaglandin synthesis, potentially responsible for regulating bone metabolism during inflammatory events. Thus, the aim of this study was to evaluate the role of the enzyme cyclooxygenase in pulp inflammation and periapical bone resorption after inoculation of bacterial lipopolysaccharide (LPS) in the pulp chamber of mouse molars. One hundred and forty four mice were C57BL/6 mice were inoculated in which the pulp chamber of the first molar with a solution containing $E$. coli LPS $(1.0 \mathrm{mg} / \mathrm{ml})$. After experimental periods of 7, 14, 21 and 28 days, the animals were euthanized and the blocks containing teeth and bone were removed to histotechnical processing and RNA extraction. The effects of pharmacologic blockade with indomethacin (non-selective COX inhibitor) and celecoxib (selective COX-2) on the expression of RANK, RANKL, OPG and other genes involved in bone metabolism were investigated. Histological sections were made and stained with hematoxylin and eosin, marked for immunohistochemistry for COX-2 and analyzed by conventional light microscopy. The recruitment of polymorphonuclear and mononuclear inflammatory cells to the pulp tissue was evaluated in three regions of the root pulp (cervical, middle and apical). Then, the evaluation of gene expression by reverse transcription and polymerase chain reaction was performed in real-time (qRT-PCR) using the TaqMan system and using a PCR assay Array (Osteogenesis profiler PCR array RT2). LPS inoculation of mice in the pulp chamber molar was able to induce the expression of Ptgs2 gene responsible for encoding COX-2 enzyme involved in the metabolism of arachidonic acid, as well as receptors for $\mathrm{PGE}_{2}$ Ptger1, Ptger3 and Ptger4. Simultaneously there was induction of the expression of genes Tnfrsf11a, Tnfrsf $11 \mathrm{~b}$ and Tnfsf11 responsible for encoding modulators of osteoclastogenesis RANK, OPG and RANKL, respectively. Celecoxib and Indomethacin, non-selective and selective inhibitors of COX-2, respectively, differentially modulate expression of genes Tnfrsf11a, Tnfrsf11b and Tnfsf11. Histologically, the drugs used did not inhibit the development of bone resorption in the periapical region. During the period of 28 days in the animals inoculated and LPS was administered Indomethacin was observed a significant increase of the periapical lesion. Some genes related to bone anabolism had to be increased in the initial stages of response to LPS inoculation in the pulp chamber, with the inhibition of the cyclooxygenase, such as Bmpr1b, Col10a1, Col14a1, Col17a1, Ahsg and Msx1. Considering that Celecoxibe and Indomethacin modulated differentially expression of genes involved in bone metabolism after inoculation of LPS, there seems to be a distinct role for COX-1 and COX-2 in periapical lesion development.

Key-words: bacterial lipopolysaccharide, cyclooxygenase, osteoclastogenesis, bone metabolism, Indomethacin, Celecoxib, inflammation. 



\section{SUMÁRIO}

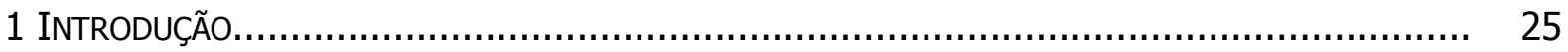

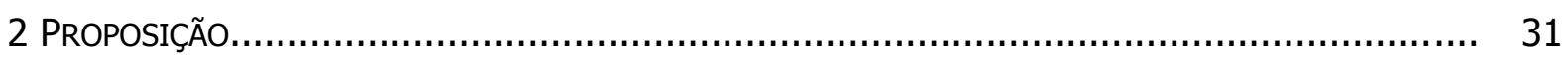

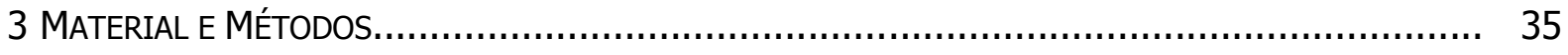

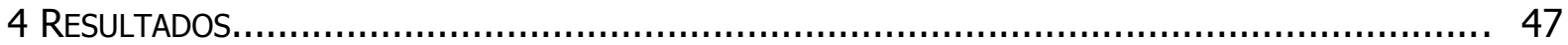

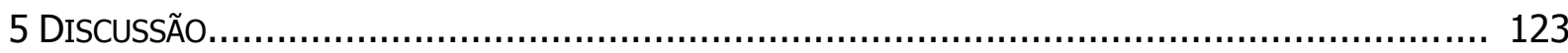

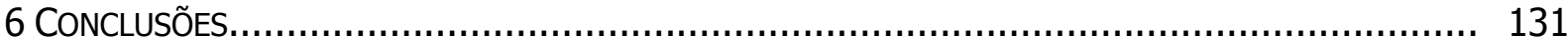

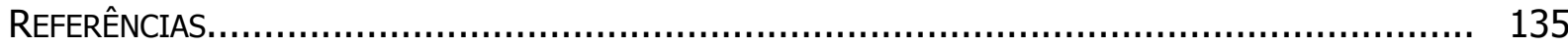

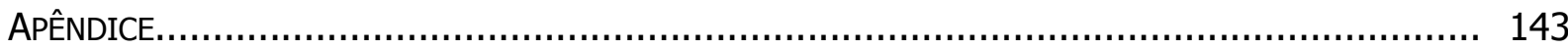

ANEXO A 



$$
\text { INTRODUÇÃO }
$$





\section{INTRODUÇÃO}

O tecido conjuntivo pulpar encontra-se localizado no interior dos canais radiculares do elemento dental e apresenta capacidade de defesa diante de estímulos próinflamatórios provenientes das lesões de cárie (Lee et al., 2006; Paula-Silva et al., 2009d). Quando essa defesa é vencida, a polpa dental se torna contaminada, o tecido pulpar é destruído e ocorre o surgimento da lesão periapical (Martón e Kiss, 2000; Menezes-Silva et al., 2012).

A lesão periapical é caracterizada por uma reposta imuno-inflamatória localizada, direcionada contra os micro-organismos presentes no interior do canal radicular e câmara pulpar (Martón e Kiss, 2000; Prahlad et al., 2014), com a presença de um infiltrado inflamatório misto, composto por neutrófilos, macrófagos, linfócitos T e B e plasmócitos (Liapatas et al., 2003). No infiltrado inflamatório periapical, dois padrões de resposta podem ser gerados, o tipo T helper 1 (Th1) e T helper 2 (Th2), caracterizados pela produção de interleucina-2 (IL-2), interleucina-12 (IL-12) e interferon gama (INF- $\mathrm{Y}$ ), e por interleucina-4 (IL-4), interleucina-5 (IL-5), interleucina-6 (IL-6), interleucina-10 (IL-10) e interleucina-13 (IL-13), respectivamente (Jankovic et al., 2001; Abbas et al., 2008; De-Rossi et al., 2008). Diversos micro-organismos, incluindo bactérias, induzem o recrutamento de células Th1, as quais produzem IFN- $\gamma$, citocina responsável pela ativação de fagócitos (Abbas et al., 2008; Liu e Peng, 2013). A resposta inflamatória não controlada na região periapical leva à reabsorção dos tecidos ósseo e dentário (Martón e Kiss, 2000; Suzuki et al., 2002; Virtej et al, 2013).

O lipopolissacarídeo bacteriano (LPS) ou endotoxina é um componente das bactérias Gram-negativas e estimulador da resposta imunológica, liberado principalmente com a morte dessas bactérias (Graunaite et al., 2011). O LPS está presente na parede celular das bactérias Gram-negativas e contém tanto componentes lipídicos quanto porções polissacarídicas, sendo o lípide A considerado a porção tóxica da molécula (Rietschel e Brade, 1992; Abbas et al., 2008). Durante o processo de morte ou multiplicação celular, ocorre a liberação da endotoxina bacteriana, estimulando uma série de efeitos biológicos que conduzem à ocorrência de uma reação inflamatória e consequente reabsorção óssea (Silva et al., 2008).

Durante a resposta inflamatória, diversos mediadores bioquímicos são liberados com o objetivo de estimular a resposta imune celular e humoral. Dentre estes mediadores inflamatórios estão os eicosanoides, os quais são sintetizados a partir da metabolização do ácido araquidônico, produzido pela ação das enzimas fosfolipases. Por 
meio da ação das enzimas ciclo-oxigenases (COX) ou lipoxigenases (LO) ocorrerão modificações estruturais na cadeia do ácido araquidônico, levando a síntese de prostaglandinas e tromboxanos ou leucotrienos e lipoxinas, respectivamente (Fiorucci et al., 2001; Clària, 2003; Zhang et al., 2003; Robbins et al., 2010; Kovác e Kovác, 2011).

Quando ocorre estresse celular, quer seja físico, bioquímico ou funcional, os fosfolipídeos constituintes da membrana citoplasmática são utilizados para síntese de prostaglandinas e leucotrienos. Este processo inicia-se devido a uma redução da concentração intracelular de trifosfato de adenosina (ATP), o que leva a um decorrente aumento da permeabilidade ao cálcio, com maior influxo para o interior da célula. Muitas vias metabólicas são ativadas pelo cálcio, dentre elas as vias da fosfolipase $A_{2}$ e fosfolipase $C$, as quais levam à fragmentação dos fosfolipídios das membranas celulares e geração de moléculas de ácido araquidônico (Fiorucci et al., 2001; Clària e Romano, 2005; GonzalezPériz e Clària, 2007; Massoumi e Sjolander, 2007; Pidgeon et al., 2007; Consolaro et al., 2009; Robbins et al., 2010; Steinhilber et al., 2010).

A enzima ciclo-oxigenase pode se apresentar em distintas isoformas, denominadas COX-1 e COX-2. A COX-1 é produzida em resposta a estímulos inflamatórios e também se expressa constitutivamente na maioria dos tecidos. Assim, a COX-1 é responsável não somente pela produção de prostaglandinas envolvidas na inflamação, mas também atua na homeostasia. Por outro lado, a COX-2 estimula a produção de prostaglandinas envolvidas na reação inflamatória e não é encontrada na maioria dos tecidos em condições normais (Charlier e Michaux, 2003; Clària, 2003; Consolaro et al., 2009; Robbins et al., 2010). A endotoxina estimula os leucócitos a liberarem citocinas, tais como IL-1 e TNF, que aumentam a síntese da enzima COX-2 (Leonardo et al., 2004; Abbas et al., 2008; Martinho et al., 2012).

Mediadores lipídicos como a prostaglandina $\mathrm{E}_{2}\left(\mathrm{PGE}_{2}\right)$ e os leucotrienos $\mathrm{B}_{4}$ e $\mathrm{C}_{4}$ foram previamente demonstrados em lesões periapicais de humanos (Torabinejad et al., 1992). A presença de $\mathrm{PGE}_{2}$ tem sido constatada na região de tecidos pulpares inflamados e em lesão periapical, sua relação com aumento de permeabilidade vascular e degradação de colágeno tem sido demonstrada (Martinho et al., 2012). Experimentalmente, a contaminação dos canais radiculares em ratos submetidos ao tratamento com corticosteróide (Dexametasona) levou ao desenvolvimento de lesões periapicais de menor extensão se comparados ao grupo controle (sem Dexametasona) (Metzger et al., 2002), sugerindo que os eicosanoides estão envolvidos no desenvolvimento da lesão periapical. Ainda, a administração de um medicamento inibidor não-seletivo das ciclo-oxigenases (Indometacina) durante o desenvolvimento da lesão periapical resultou em menor intensidade do infiltrado 
inflamatório concomitantemente a menor reabsorção do tecido ósseo (Oguntebi et al., 1989). A utilização de um inibidor seletivo para COX-2 (Celecoxibe) impediu a formação de osteoclastos, indicando um papel essencial das prostaglandinas na reabsorção óssea (Kawashima et al., 2009; Naidu et al., 2013). Outros estudos em roedores (Bezerra et al., 2000; Lin et al., 2002; Gurgel et al., 2004; Vardar et al., 2005; Holzhausen et al., 2009) têm demonstrado que o uso de drogas anti-inflamatórias não-esteróides (AINEs), inibidoras da enzima ciclo-oxigenase, podem levar a redução da inflamação e perda óssea. A relação entre os níveis de $\mathrm{COX}-2$ e a síntese de $\mathrm{PGE}_{2}$ durante o processo inflamatório foi demonstrada previamente, podendo promover reabsorção óssea através da modulação de MMP-1 e IL-6 (Lin et al., 2002).

A reabsorção óssea é um processo caracterizado por uma série de etapas, sendo iniciado com a proliferação de precursores de osteoclastos advindos de monócitos da linhagem hematopoiética, seguindo com a sua diferenciação e maturação, levando finalmente a degradação de matrizes orgânicas colagênicas e inorgânicas do tecido ósseo, por meio da ação de metaloproteinases da matriz (Tay et al., 2004; Gallagher, 2008; PaulaSilva et al., 2010; Trouvin e Goeb, 2010; Wan et al., 2014).

Diversas citocinas e fatores de crescimento são essenciais para diferenciação e maturação dos osteoclastos. Dentre esses, podemos citar as interleucinas (IL-1, IL-3, IL-6, IL-11, IL-15, IL-17, IL-18), fator de necrose tumoral-alfa (TNF-a) e fator estimulador de formação de colônia de monócitos (MCSF-2 e MCSF-3) (Bar-Shavit, 2007; Liu e Peng, 2013). Esses fatores atuam pela estimulação das células progenitoras de osteoclastos ou participando em um sistema parácrino, no qual estão envolvidos os osteoblastos e células da medula óssea. Este sistema parácrino é essencial para o metabolismo do osso e seus mediadores incluem as moléculas RANK (Receptor Ativador do Fator Nuclear kappa B), ligante para RANK (RANKL) e OPG (Osteoprotegerina).

O sistema RANK/RANKL/OPG é responsável pela modulação da osteoclastogênese, onde RANK é o receptor que está expresso na superfície dos osteoclastos e seus progenitores, células dendríticas e células T ativadas (Boyle et al., 2003; Lerner, 2004). RANKL é um mediador solúvel sintetizado por osteoblastos e células endoteliais, que ativa os osteoclastos quando se liga ao seu receptor, RANK (Neumann et al., 2014). RANKL é um membro da superfamília do fator de necrose tumoral, sendo considerada a mais importante citocina envolvida em vários estágios da reabsorção óssea (Leibbrandt e Penninger, 2008; Neumann et al., 2014). Este mediador também é necessário para induzir a expressão de genes que especificam a linhagem osteoclástica, incluindo os genes que codificam a enzima fosfatase ácida resistente ao tartarato (TRAP), catepsina $\mathrm{K}$ e o receptor 
para calcitonina, conduzindo assim à maturação de osteoclastos (Boyle et al., 2003; Lau et al., 2005; Lange et al., 2013).

Os efeitos de RANKL são bloqueados por receptores solúveis, como a osteoprotegerina (OPG), secretada por osteoblastos (Lerner, 2004). A OPG é caracterizada por ser um receptor solúvel, que ao se ligar a RANKL, impede sua ligação ao receptor RANK, inibindo a diferenciação de osteoclastos (Jin et al., 2007; Lange et al., 2013; Neumann et al., 2014). A superexpressão de OPG bloqueia a maturação dos osteoclastos, levando ao desenvolvimento de osteopetrose em ratos, bem como a deleção do gene para OPG resulta no aumento da remodelação óssea, induzindo o desenvolvimento de osteoporose (Kearns et al., 2008; Anandarajah, 2009).

Previamente, nosso grupo de pesquisa observou que a inoculação de LPS nos canais radiculares de molares de camundongos foi capaz de induzir a expressão dos genes Ptgs2 e Alox5, responsáveis pela codificação das enzimas COX-2 e 5-LO, envolvidas no metabolismo do ácido araquidônico, concomitantemente à modulação da expressão dos genes Tnfrsf11a, Tnfsf11 e Tnfrsf11b, responsáveis pela codificação dos moduladores da osteoclastogênese RANK, RANKL e OPG, respectivamente. A inibição não seletiva de COX-2 levou a regulação de genes importantes para o metabolismo ósseo, sugerindo que esta via poderia ser um alvos terapêutico importantes para intervenção em doenças inflamatórias, como lesões periapicais, para evitar a reabsorção do tecido ósseo (Santos, 2012). Assim, tornou-se necessária a realização de uma investigação dos mediadores da osteoclastogênese e enzimas envolvidas no metabolismo do ácido araquidônico após a utilização de Celecoxibe (inibidor seletivo) e não-seletivo (Indometacina) da enzima ciclooxigenase-2, por meio de avaliação histológica e imunoistoquímica, para avaliar o efeito destes medicamentos no processo de reabsorção óssea induzida pelo LPS. 
Proposiçáa 



\section{PROPOSIÇÃo}

\section{Objetivo geral:}

O objetivo geral deste estudo foi avaliar o papel da via ciclo-oxigenase na inflamação pulpar e reabsorção óssea periapical, assim como na expressão de mediadores da osteoclastogênese e genes envolvidos no metabolismo ósseo, após inoculação de lipopolissacarídeo bacteriano (LPS) na câmara pulpar de molares de camundongos.

\section{Objetivos específicos:}

- Realizar a técnica de qRT-PCR para verificação da expressão gênica, com análise do RNA responsável pela síntese da proteína em questão;

- Realizar a técnica de qRT-PCR Array para verificação da expressão gênica de genes relacionados a osteoclastogênese, agrupados de acordo com sua função, fatores de crescimento e diferenciação celular, constituintes estruturais da matriz extracelular (proteínas colagênicas e nãocolagênicas), moléculas de adesão celular e fatores de transcrição;

- Mensurar a extensão da área microscópica correspondente às lesões periapicais por microscopia convencional;

- Efetuar a contagem do número de células inflamatórias (mononucleares, polimorfonucleares) e fibroblastos, no tecido pulpar e periapical em microscopia de luz convencional;

- Realizar a técnica de imunohistoquímica para a identificação de células marcadas para COX-2. 

Materiale Métodos 



\section{Material e Métodos}

\section{Animais}

O presente estudo foi aprovado pela Comissão de Ética no Uso de Animais, do Campus de Ribeirão Preto, da Universidade de São Paulo (USP), processo nº 13.1.266.53.6. Foram utilizados 144 camundongos (Mus musculus) C57BL/6, machos, com 6 semanas de idade, pesando de 18 a 20 gramas, provenientes do Biotério Central da USP. Os animais foram mantidos no Biotério da Faculdade de Odontologia de Ribeirão Preto para ambientação por 7 dias, previamente à realização dos experimentos. Durante todo o período experimental os animais foram alocados em gaiolas de polipropileno e tampas de aço inoxidável perfurado, de $15 \times 20 \mathrm{~cm}$ ( 6 animais por gaiola), forradas com maravalha autoclavada, em temperatura de $22^{\circ} \mathrm{C}$ e umidade relativa do ar (55 $\left.\pm 10 \%\right)$ constantes, em um ciclo de claro-escuro de 12 : 12 horas, com dieta padrão de laboratório e livre acesso à água filtrada.

\section{Procedimentos Operatórios}

Para a realização dos procedimentos operatórios os animais foram anestesiados com cloridrato de ketamina (150 mg/kg; Ketamina 10\%; Agener União Química Farmacêutica Nacional S/A, Embu-Guaçu, SP) e xilazina (7,5 mg/kg; Dopaser, Laboratórios Calier S/A, Barcelona, Espanha), por via intramuscular na coxa traseira.

\section{Inoculação de LPS na câmara pulpar e tratamamento com inibidor farmacológico.}

Os animais foram posicionados em uma mesa cirúrgica com dispositivo para retração mandibular, permitindo a imobilização dos mesmos e manutenção da boca aberta, para acesso aos molares. Os primeiros molares superiores (direito e esquerdo) e primeiros molares inferiores (direito e esquerdo) de cada animal foram utilizados para experimentação, sendo o lado direito sempre utilizado para inoculação de LPS na câmara pulpar e o lado esquerdo utilizado como controle.

A abertura coronária foi realizada pela face oclusal, utilizando uma ponta diamantada esférica tamanho 1/4 (KG Sorensen Ind. Com. Ltda., Barueri, Brasil). A polpa coronária foi removia e na câmara pulpar foi inoculada uma suspensão de lipopolissacarídeo bacteriano de Escherichia coli (0127:B8 (L3129; Sigma-Aldrich Corp., St. Louis, EUA) resuspenso em solução salina, na concentração de $1 \mathrm{mg} / \mathrm{ml}$ (determinada em estudo prévio - Santos, 2012). Em cada dente foram inoculados $10 \mu \mathrm{L}$ da suspensão, por meio de uma micropipeta automática e as cavidades foram selados com cimento de ionômero de vidro 
convencional (S.S. White Artigos Dentários Ltda, Rio de Janeiro, Brasil), manipulado de acordo com as instruções do fabricante. Dentes hígidos, sem exposição pulpar, foram utilizados como controle. Os grupos foram subdivididos em 4 subgrupos experimentais (cada subgrupo contendo $\mathrm{n}=6$ camundongos; $\mathrm{n}=12$ dentes), de acordo com o período de avaliação, aos 7, 14, 21 e 28 dias após a inoculação de LPS na câmara pulpar.

Para inibição farmacológica da via ciclo-oxigenase foram utilizados a Indometacina $\left(\mathrm{C}_{19} \mathrm{H}_{16} \mathrm{ClNO}_{4}\right.$; Cayman Chemical, Ann Arbor, EUA) diluída em 5\% de $\mathrm{NaHCO}_{3}$ em solução salina, na concentração de $5 \mathrm{mg} / \mathrm{kg}$ de peso (Santos, 2012), administrada por gavagem, aplicada uma hora antes da inoculação de LPS nos dentes de camundongos e diariamente durante todo o período de experimentação $(n=24)$ e o Celecoxibe $\left(\mathrm{C}_{17} \mathrm{H}_{14} \mathrm{~F}_{3} \mathrm{~N}_{3} \mathrm{O}_{2} \mathrm{~S}\right.$; Pfizer Inc., La Jolla, CA, EUA), administrado por gavagem, uma hora antes da inoculação de LPS e diariamente durante todo o período de experimentação $(n=24)$, na concentração de $15 \mathrm{mg} / \mathrm{kg}$ de peso (Machado et al., 2010).

Um grupo de animais recebeu a solução veículo, sem Indometacina ou Celecoxibe, sendo os dentes hígidos, sem exposição pulpar, utilizados como controle negativo e dentes inoculados com LPS utilizados como controle positivo $(n=24)$.

\section{Eutanásia}

Decorridos os períodos experimentais determinados, os animais foram submetidos à eutanásia por sobredose anestésica, via intramuscular, com a utilização de Ketamina a $10 \%$ (300 mg/kg) e Xilazina (30 mg/kg). Os tecidos foram removidos com auxílio de tesoura e reduzidos em blocos contendo dente e osso. Parte dos tecidos $(n=6$ dentes por grupo, por período experimental) foram acondicionados em tubos de 1,5 $\mathrm{ml}$ esterilizados e livres de RNAse (Axygen Inc., Union City, EUA) e imersos em gelo seco, previamente ao congelamento a $-20^{\circ} \mathrm{C}$.

\section{Extração de RNA total}

Para extração de RNA total foi utilizado um pool contendo 3 dentes molares, com peso total médio de $30 \mathrm{mg}$, por meio do RNeasy Mini kit, um protocolo de extração à base de tiocianato de guanidina (RNeasy ${ }^{\circledR}$ Mini, Qiagen Inc., Valencia, EUA). Os blocos contendo dente e osso foram macerados com auxílio de pinça hemostática, em tubo de 1,5 $\mathrm{ml}$ esterilizado e livre de RNAse (Axygen Inc.), contendo $594 \mu \mathrm{l}$ de solução tampão RLT e 6 $\mu \mathrm{L}$ de beta-mercaptoetanol ( $\beta \mathrm{ME})$. Com a finalidade de lisar e homogeneizar as amostras, os tubos foram agitados em vórtex (IKA ${ }^{\circledR}$ MS3 Basic, IKA ${ }^{\circledR}$ Works Inc., Wilmington, EUA) por 1 minuto e, a seguir, submetidos ao ultrassom por 15 minutos (Unique Ind. e Com. Equipamentos Eletrônicos, Indaiatuba, Brasil). A seguir os tubos foram centrifugados em microcentrífuga (Microcentrífuga modelo 5417R; Eppendorf AG, Hamburg, Germany), a 
$10.000 \mathrm{rpm}$, por 3 minutos. O sobrenadante foi transferido para um novo tubo e adicionado 1 volume de etanol a 70\%, preparado com água livre de RNase, com a finalidade de fornecer condição apropriada para ligação do RNA à coluna de purificação. A seguir $600 \mu \mathrm{l}$ da solução foram transferidos para uma coluna contendo um tubo coletor acoplado e os tubos foram centrifugados a $10.000 \mathrm{rpm}$, por 15 segundos. O filtrado foi descartado e os 600 $\mu \mathrm{l}$ restantes da solução foram transferidos para a coluna e centrifugados novamente. 0 filtrado foi descartado, $350 \mu \mathrm{L}$ da solução tampão RW1 foram adicionados à coluna e os tubos foram centrifugados a $10.000 \mathrm{rpm}$, por 15 segundos. A seguir $10 \mu \mathrm{L}$ de DNAse I foram diluídos em $70 \mu \mathrm{L}$ de solução tampão RDD (RNase-Free DNase Set; Qiagen Inc.), o volume total foi adicionado à membrana presente na coluna e as colunas foram incubadas a $25^{\circ} \mathrm{C}$, por 15 minutos, para eliminar a possível contaminação com DNA genômico. A seguir $350 \mu \mathrm{L}$ da solução tampão RW1 foram adicionados à coluna e os tubos foram centrifugados a 10.000 rpm, por 15 segundos. Posteriormente $500 \mu \mathrm{L}$ de solução tampão RPE contendo etanol foram adicionados à coluna e os tubos foram centrifugados a $10.000 \mathrm{rpm}$, por 15 segundos. Novamente $500 \mu \mathrm{L}$ de solução tampão RPE contendo etanol foram adicionados à coluna e os tubos foram centrifugados a $10.000 \mathrm{rpm}$, por 2 minutos. Com a finalidade de eliminar a possibilidade de carregar remanescentes de solução tampão RPE contendo etanol para as etapas seguintes, o tubo coletor foi descartado, um novo tubo coletor foi inserido na coluna e os tubos foram centrifugados a $13.000 \mathrm{rpm}$, por 1 minuto. O tubo coletor foi descartado, um tubo de $1,5 \mathrm{ml}$ foi acoplado à coluna e o RNA presente na membrana foi eluído em $35 \mu \mathrm{L}$ de água livre de RNase.

A qualidade do RNA total foi avaliada por meio de eletroforese em gel de agarose a $1 \%$ (Sigma-Aldrich Corp.) contendo brometo de etídeo (Sigma-Aldrich Corp.), utilizando tampão TBE (Tris-Borato-EDTA) concentrado $1 \times$. Foram analisadas as duas bandas correspondentes ao RNA ribossomal $28 \mathrm{~S}$ e $18 \mathrm{~S}$ e o RNA foi considerado de boa qualidade quando a relação $28 \mathrm{~S} / 18 \mathrm{~S}$ fosse igual ou maior que 2. A pureza e estimação da quantidade de ácidos nucleicos foi analisada utilizando espectrofotometria em NanoDrop 1000 (Thermo Fisher Scientific Inc., Wilmington, EUA), nos comprimentos de onda de 230, 260 e $280 \mathrm{~nm}$.

\section{Transcrição reversa e reação da polimerase em cadeia em tempo real (qRT-PCR)}

Para as reações de qRT-PCR pelo sistema $\operatorname{TaqMan}^{\circledR}$, o cDNA foi sintetizado por meio de uma reação de transcrição reversa, a partir de 500 ng de RNA total, utilizando o kit High Capacity cDNA Reverse Transcription (Applied Biosystems, Foster City, EUA). Em um tubo de $0,2 \mathrm{ml}$ (Axygen Inc.), o RNA foi incubado com 2,0 $\mu \mathrm{L}$ de solução tampão $10 \times, 0,8$ $\mu \mathrm{L}$ de dNTP mixture $25 \times(100 \mathrm{mM}), 2,0 \mu \mathrm{L}$ de random primers $10 \times, 1,0 \mu \mathrm{L}$ da enzima Multiscribe $^{\mathrm{TM}}$ Reverse Transcriptase $(50 \mathrm{U} / \mu \mathrm{L}), 1,0 \mu \mathrm{L}$ de inibidor de RNase e acrescido de 
água livre de RNAse para um volume final de $20 \mu \mathrm{L}$. As amostras foram incubadas a $25^{\circ} \mathrm{C}$ por 10 minutos para ligação do primer ao RNA, seguido por incubação a $37^{\circ} \mathrm{C}$ por 2 horas para transcrição reversa e posterior incubação a $85^{\circ} \mathrm{C}$ por 5 segundos para inativação da enzima e finalização do processo. O cDNA resultante foi armazenado a $-20^{\circ} \mathrm{C}$ até o momento do uso.

Para as reações de qRT-PCR, alíquotas de $2 \mu \mathrm{l}$ (50 ng) de cDNA foram adicionadas a 10,0 $\mu \mathrm{L}$ de TaqMan Universal PCR Master Mix 2×, 1,0 $\mu \mathrm{L}$ de TaqMan Gene Expression Assay 20× (par de primers + sonda) e acrescido de água livre de RNAse para um volume final de $20 \mu \mathrm{L} /$ poço. Primers e sondas para Ptgs2 (Mm00478374), Tnfrsf11a (Mm00437135), Tnfsf11 (Mm00441906), Tnfrsf11b (Mm01205928), Ptger1 (Mm00443098), Ptger2 (Mm00436051), Ptger3 (Mm01316856) e Ptger4 (Mm00436053) foram obtidos comercialmente e são propriedades privadas, portanto as sequências não estão disponíveis (TaqMan ${ }^{\circledR}$ Gene Expression Assay, Applied Biosystems). O gene para a enzima gliceraldeido3-fosfato desidrogenase (Gapdh; Mm99999915) foi utilizado como referência. Para o sistema $\operatorname{TaqMan}^{\circledR}$, foram utilizados primers na concentração final de $900 \mathrm{nM}$ cada e sonda MGB (Minor Groove Binding) na concentração final de 250 nM. Neste sistema, o fluoróforo 6-FAM foi utilizado como repórter, o qual foi liberado após clivagem pela polimerase com atividade exonuclease 5'. Para as reações de qRT-PCR foram realizados dois experimentos independentes, em duplicata, utilizando o Eppendorf Mastercycler ${ }^{\circledR}$ ep Realplex (Eppendorf $A G)$.

A amplificação foi realizada sob as seguintes condições: ativação da polimerase AmpliTaq Gold Enzyme a $95^{\circ} \mathrm{C}$ por 10 minutos, seguida por 40 ciclos de $95^{\circ} \mathrm{C}$ por 15 segundos para desnaturação do DNA e $60^{\circ} \mathrm{C}$ por 1 minuto para anelamento do primer e polimerização. Os resultados foram analisados com base no valor do ciclo limiar (Ct, cicle threshold), sendo este o ponto correspondente ao número do ciclo no qual a amplificação das amostras atinge um limiar. Este limiar foi determinado entre o grau de fluorescência dos controles negativos e a fase de amplificação exponencial das amostras que permitiu a análise quantitativa da expressão do gene avaliado. Como controle negativo foi utilizada água destilada deionizada, submetida à reação com cada par das sequências dos primers e sondas utilizados.

Para normalizar os valores de $\mathrm{Ct}$, de forma a considerar diferenças causadas por quantidades distintas de cDNA utilizadas nas reações, o Ct determinado para uma amostra foi subtraído do Ct do gene constitutivo (Gapdh) da mesma amostra, gerando assim o $\Delta$ Ct. Para cada gene, o cálculo de expressão relativa foi realizado a partir da diferença entre o $\Delta \mathrm{Ct}$ das amostras e o $\Delta \mathrm{Ct}$ apresentado pelo controle $(\Delta \Delta \mathrm{Ct})$, com base na equação: Expressão relativa $=2^{\Delta \Delta C t}$. 
Os valores de expressão relativa de cada RNAm, para cada grupo, foram comparados por meio da análise de variância (ANOVA) de duas vias seguido pelo pós-teste de Bonferroni $(a=0,05)$.

\section{Transcrição reversa e qRT-PCR Array}

A análise global da expressão de RNAm para proteínas envolvidas no metabolismo ósseo foi realizada por meio de um ensaio de qRT-PCR PCR Array (Osteogenesis RT2 2 Profiler PCR Array, PAMM-026; Qiagen Inc.). Esta técnica utiliza as vantagens do qRT-PCR combinada com a técnica de microarray que permite detectar a expressão de diferentes genes simultaneamente.

Para esta técnica, o cDNA foi sintetizado por meio de uma reação de transcrição reversa, a partir de $200 \mathrm{ng}$ de RNA total, utilizando o kit RT ${ }^{2}$ First Strand (Qiagen Inc.). Em um tubo de $0,2 \mathrm{ml}$, o RNA foi incubado com $6,0 \mu \mathrm{L}$ de solução tampão GE2 e acrescido de água livre de RNAse para um volume final de $14 \mu \mathrm{L}$. Os tubos foram mantidos ao abrigo da luz, a $25^{\circ} \mathrm{C}$, por 10 minutos e, a seguir, foram adicionados $6 \mu \mathrm{L}$ da Reverse Transcriptase Mixture BC4. Os tubos foram centrifugados e incubados a $42^{\circ} \mathrm{C}$ por 15 minutos para ligação do primer ao RNA e transcrição reversa, seguido por incubação a $95^{\circ} \mathrm{C}$ por 5 minutos para inativação da enzima e, posteriormente, mantidos a $4^{\circ} \mathrm{C}$. Ao cDNA resultante foi adicionado $91 \mu \mathrm{L}$ de água livre de RNase para um volume final de $111 \mu \mathrm{L}$, o qual foi armazenado a $-20^{\circ} \mathrm{C}$ até o momento do uso.

Para este estudo o PCR array foi composto por 84 genes, os quais foram agrupados de acordo com sua função, em fatores de crescimento e diferenciação celular, constituintes estruturais da matriz extracelular (proteínas colagênicas e não-colagênicas), moléculas de adesão celular e fatores de transcrição. Os genes constitutivos Gusb, Hprt, Hsp90ab1, Actb e Gapdh foram utilizados como referência. Foram incluídos em cada placa, controles para detecção de contaminação por DNA genômico de camundongos (MGDC), controles para testar a eficiência da reação de transcrição reversa (RTC) e os controles positivos (PPC) que consistem em uma sequência de DNA artificial passível de ser detectada durante a reação (Tabela 1 ).

Para cada amostra, $102 \mu \mathrm{l}$ de cDNA foram adicionados a $1350 \mu \mathrm{L}$ de $\mathrm{RT}^{2}$ SYBR Green Master Mix 2× e acrescido de água livre de RNAse para um volume final de $2700 \mu \mathrm{L}$. Desta solução, $25 \mu \mathrm{l}$ foram depositados em cada poço, o qual teve cada par de primers do PCR Array. Para as reações de qRT-PCR foram realizados dois experimentos independentes, em duplicata, utilizando o Eppendorf Mastercycler ${ }^{\circledR}$ ep Realplex (Eppendorf AG).

Para a reação de qRT-PCR foi utilizada a tecnologia SYBR Green, na qual o número de cópias amplificadas de um determinado gene é proporcional à fluorescência quantificada pelo equipamento, oriunda da liberação de fluorocromo. Este fluorocormo 
encontra-se ligado à dupla fita formada pela associação de uma sonda específica e o cDNA na região do gene de interesse.

A amplificação foi realizada sob as seguintes condições: ativação da polimerase HotStart DNA Taq Polymerase a $95^{\circ} \mathrm{C}$ por 10 minutos, seguida por 40 ciclos de $95{ }^{\circ} \mathrm{C}$ por 15 segundos para desnaturação do DNA e $60{ }^{\circ} \mathrm{C}$ por 1 minuto para anelamento do primer e polimerização. Ao final da reação, foi avaliada a curva de dissociação (Melting curve) para determinação da especificidade dos primers considerando a temperatura de fusão dos amplicons, sob as seguintes condições: aumento da temperatura a $95{ }^{\circ} \mathrm{C}$ por 15 segundos, seguido por diminuição da temperatura a $60^{\circ} \mathrm{C}$ por 15 segundos, aumento gradual da temperatura até $95^{\circ} \mathrm{C}$ por 20 minutos e manutenção a $95^{\circ} \mathrm{C}$ por 15 minutos.

Os resultados foram analisados com base no valor de cada $\mathrm{Ct}$, para cada RNAm. Para normalizar os valores de $\mathrm{Ct}$, de forma a considerar diferenças causadas por quantidades distintas de cDNA utilizadas nas reações, o Ct determinado para uma amostra foi subtraído da média geométrica dos Cts dos genes constitutivos (Gusb, Hprt, Hsp90ab1, Actb e Gapdh) da mesma amostra, gerando assim o $\Delta$ Ct. Para cada gene, o cálculo de expressão relativa foi realizado a partir da diferença entre o $\Delta \mathrm{Ct}$ das amostras e o $\Delta \mathrm{Ct}$ apresentado pelo controle $(\Delta \Delta \mathrm{Ct})$, com base na equação descrita previamente. 
Tabela 1. Genes avaliados no PCR Array para proteínas envolvidas no metabolismo ósseo (Osteogenesis $\mathrm{RT}^{2}$ Profiler PCR Array)

\begin{tabular}{|c|c|c|c|c|c|}
\hline GeneBank & Símbolo & Nomenclatura & GeneBank & Símbolo & Nomenclatura \\
\hline NM_013465 & Ahsg & Alfa-2-HS-Glicoproteína & NM_010512 & Igf1 & Fator de crescimento semelhante à insulina 1 \\
\hline NM_007431 & $A / p /$ & Fosfatase alcalina & NM_010513 & Igf1r & $\begin{array}{l}\text { Receptor para o fator de crescimento } \\
\text { semelhante à insulina } 1\end{array}$ \\
\hline NM_009664 & $A m b n$ & Ameloblastina & NM_008396 & Itga2 & Integrina alfa 2 \\
\hline NM_009673 & Anxa5 & Anexina A5 & NM_010575 & Itga $2 b$ & Integrina alfa $2 b$ \\
\hline NM_007542 & Bgn & Biglicano & NM_013565 & Itga3 & Integrina alfa 3 \\
\hline NM_009755 & Bmp1 & Proteína óssea morfogenética 1 & NM_008401 & Itgam & Integrina alfa $\mathrm{M}$ \\
\hline NM_007553 & $B m p 2$ & Proteína óssea morfogenética 2 & NM_008402 & Itgav & Integrina alfa $\mathrm{V}$ \\
\hline NM_173404 & Bmp3 & Proteína óssea morfogenética 3 & NM_010578 & Itgb1 & Integrina beta 1 (Receptor para fibronectina) \\
\hline NM_007554 & Bmp4 & Proteína óssea morfogenética 4 & NM_008610 & Mmp2 & Metalopeptidase da matriz 2 \\
\hline NM_007555 & Bmp5 & Proteína óssea morfogenética 5 & NM_008611 & Mmp8 & Metalopeptidase da matriz 8 \\
\hline NM_007556 & Bmp6 & Proteína óssea morfogenética 6 & NM_013599 & Mmpg & Metalopeptidase da matriz 9 \\
\hline NM_009758 & Bmprla & $\begin{array}{l}\text { Receptor para proteína óssea } \\
\text { morfogenética, tipo } 1 \mathrm{~A}\end{array}$ & NM_019471 & Mmp10 & Metalopeptidase da matriz 10 \\
\hline NM_007560 & Bmpr1b & $\begin{array}{l}\text { Receptor para proteína óssea } \\
\text { morfogenética, tipo } 1 \mathrm{~B}\end{array}$ & NM_010835 & MsX1 & Osterix \\
\hline NM_007643 & Cd36 & CD36 & NM_008689 & Nfkb1 & Fator de transcrição nuclear kappa B, p105 \\
\hline NM_009866 & Cdh11 & Caderina 11 & NM_008808 & Pdgfa & $\begin{array}{l}\text { Fator de crescimento derivado de plaquetas, } \\
\text { alfa }\end{array}$ \\
\hline NM_009925 & Col10a1 & Colágeno, tipo X, alfa 1 & NM_011077 & Phex & Endopeptidase regudora de fosfato, PHEX \\
\hline NM_007729 & Col11a1 & Colágeno, tipo XI, alfa 1 & NM_009820 & Runx2 & Fator de transcrição relacionado ao Runt- 2 \\
\hline NM_007730 & Col12a1 & Colágeno, tipo XII, alfa 1 & NM_016741 & Scarb1 & Receptor scavenger, classe B, tipo 1 \\
\hline NM_181277 & Col14a1 & Colágeno, tipo XIV, alfa 1 & NM_009825 & Serpinh1 & $\begin{array}{l}\text { Inibidor de peptidase serínica, clade } \mathrm{H} \text {, } \\
\text { membro } 1\end{array}$ \\
\hline NM_007742 & Colla1 & Colágeno, tipo I, alfa 1 & NM_008539 & Smad1 & SMAD 1 \\
\hline NM_007743 & Colla2 & Colágeno, tipo I, alfa 2 & NM_010754 & Smad2 & SMAD 2 \\
\hline NM_031163 & Col2a1 & Colágeno, tipo II, alfa 1 & NM_016769 & Smad3 & SMAD 3 \\
\hline NM_009930 & Col3a1 & Colágeno, tipo III, alfa 1 & NM_008540 & Smad4 & SMAD 4 \\
\hline NM_009931 & Col4a1 & Colágeno, tipo IV, alfa 1 & NM_024449 & Sost & Esclerostina \\
\hline NM_009932 & Col4a2 & Colágeno, tipo IV, alfa 2 & NM_011448 & Sox9 & Fator de transcrição SOX-9 \\
\hline NM_015734 & Col5a1 & Colágeno, tipo V, alfa 1 & NM_018783 & Tfip11 & Proteína que interagem com Tuftelina- 11 \\
\hline NM_009933 & Col6a1 & Colágeno, tipo VI, alfa 1 & NM_011577 & $T g f b 1$ & Fator de crescimento transformador, beta 1 \\
\hline NM_146007 & Col6a2 & Colágeno, tipo VI, alfa 2 & NM_009367 & $\operatorname{Tgfb2}$ & Fator de crescimento transformador, beta 2 \\
\hline NM_007738 & Col7a1 & Colágeno, tipo VII, alfa 1 & NM_009368 & Tgfb3 & Fator de crescimento transformador, beta 3 \\
\hline NM_016685 & Comp & $\begin{array}{l}\text { Proteína oligomérica da matriz } \\
\text { cartilaginosa }\end{array}$ & NM_009370 & Tgfbr1 & $\begin{array}{l}\text { Receptor para o fator de crescimento } \\
\text { transformador, beta } 1\end{array}$ \\
\hline NM_009969 & Csf2 & $\begin{array}{l}\text { Fator estimulador de colônia de } \\
\text { macrófagos e granulócitos } 2\end{array}$ & NM_009371 & Tgfbr2 & $\begin{array}{c}\text { Receptor para o fator de crescimento } \\
\text { transformador, beta } 2\end{array}$ \\
\hline NM_009971 & Csf3 & $\begin{array}{l}\text { Fator estimulador de colônia de } \\
\text { granulócitos } 3\end{array}$ & NM_011578 & Tgfbr3 & $\begin{array}{l}\text { Receptor para o fator de crescimento } \\
\text { transformador, beta } 3\end{array}$ \\
\hline NM_007802 & Ctsk & Catepsina K & NM_013693 & Tnf & Fator de necrose tumoral \\
\hline NM_016779 & Dmp1 & Proteína da matriz dentinária 1 & NM_011656 & Tuft1 & Tuftelina 1 \\
\hline NM_010113 & Egf & Fator de crescimento epidermal & NM_011658 & Twist1 & Fator de transcrição Twist-1 \\
\hline NM_017468 & Enam & Enamelina & NM_011693 & Vcam1 & Molécula de adesão celular vascular-1 \\
\hline NM_010197 & Fgf1 & $\begin{array}{l}\text { Fator de crescimento de } \\
\text { fibroblastos } 1\end{array}$ & NM_009504 & $V d r$ & Receptor para vitamina $D$ \\
\hline NM_008006 & Fgf2 & $\begin{array}{l}\text { Fator de crescimento de } \\
\text { fibroblastos } 2\end{array}$ & NM_009505 & Vegfa & Fator de crescimento endotelial vascular A \\
\hline NM_008007 & Fgf3 & $\begin{array}{l}\text { Fator de crescimento de } \\
\text { fibroblastos } 3\end{array}$ & NM_011697 & Vegfb & Fator de crescimento endotelial vascular B \\
\hline NM_010206 & Fgfr1 & $\begin{array}{c}\text { Receptor para fator de crescimento } \\
\text { de fibroblastos } 1\end{array}$ & NM_010368 & Gusb & Beta-glucuronidase \\
\hline NM_010207 & Fgfr2 & $\begin{array}{c}\text { Receptor para fator de crescimento } \\
\text { de fibroblastos } 2\end{array}$ & NM_013556 & Hprt & Hipoxantina guanina fosforibosil transferase \\
\hline NM_010228 & Flt1 & $\begin{array}{l}\text { Receptor para o fator de } \\
\text { crescimento vascular endotelial } 1\end{array}$ & NM_008302 & Hsp90ab1 & $\begin{array}{l}\text { Proteína de choque térmico } 90 \text { alfa, classe B } \\
\text { membro } 1\end{array}$ \\
\hline NM_010233 & $F n 1$ & Fibronectina 1 & NM_008084 & Gapdh & Gliceraldeído-3-fosfato desidrogenase \\
\hline NM_145741 & Gdf10 & $\begin{array}{l}\text { Fator } 10 \text { de diferenciação de } \\
\text { crescimento }\end{array}$ & NM_007393 & $A c t b$ & Beta-actina \\
\hline NM_010493 & Icam1 & Molécula de adesão intercelular 1 & & & \\
\hline
\end{tabular}




\section{Processamento Histológico}

Os blocos contendo dente e osso ( $n=6$ dentes por grupo, por período) foram submetidas à fixação em solução de formol tamponado a 10\%, por 72 horas, à temperatura ambiente. Posteriormente, foram imersos em um recipiente de vidro contendo uma solução à base de EDTA a $20 \%(\mathrm{pH} 7,4)$ e submetidos a desmineralização. A completa desmineralização das amostras, avaliada por meio da penetração de uma agulha nos tecidos para verificação da sua consistência, foi obtida em aproximadamente 15 dias. Concluída a desmineralização, as peças foram lavadas em água corrente por 24 horas, desidratadas em concentrações crescentes de álcool (Álcohol Etílico Absoluto Anhidro ${ }^{\circledR} ;$ J.T. Baker), diafanizadas em xilol (Xylol ${ }^{\circledR}$; Merck) e incluídas em parafina (Histosec ${ }^{\circledR}$ Pastillen; Merck). Os blocos contendo dente e osso foram reduzidos pela microtomia a cortes seriados longitudinais com 5,0 $\mu \mathrm{m}$ de espessura. Para avaliação histopatológica, os tecidos foram corados pela Hematoxilina e Eosina para análise histométrica e contagem de células.

\section{Avaliação histométrica}

Os cortes histológicos corados por HE foram avaliados por microscopia de luz convencional (Figura 1) e feita a mensuração das lesões periapicais (Zeiss Axio Imager, Carl Zeiss AG Light Microscopy, Göttingen, Alemanha), de acordo com parâmetros descrito previamente (Paula-Silva et al., 2009). Para a análise morfométrica do tamanho das lesões periapicais foi utilizada videomicroscopia com o Software Zeiss AxioVision (Carl Zeiss AG Light Microscopy), em conjunto com o microscópio e videocâmara AxioCam MRc5 (Carl Zeiss AG Light Microscopy), no aumento de 10×. Para cada espécime, a área da lesão periapical foi delineada e medida em $\mathrm{mm}^{2}$ nas lâminas que representavam o maior diâmetro da lesão. A delimitação da lesão excluiu as estruturas intactas (ligamento periodontal, cemento e osso alveolar), e incluiu áreas de reabsorção e infiltrado inflamatório. Os valores obtidos em cada grupo foram comparados utilizando ANOVA de duas vias seguido pelo pós-teste de Bonferroni $(a=0,05)$.

\section{Contagem do número de células inflamatórias}

As células presentes no tecido pulpar radicular, nas regiões cervical, média e apical foram agrupadas de acordo com suas características morfológicas em células inflamatórias polimorfonucleadas, células inflamatórias mononucleadas e fibroblastos. $\mathrm{O}$ número de células foi estimado em 3 campos representativos de cada corte, sendo utilizados 3 cortes por espécime, no aumento de 40× (Figura 1). Para avaliação da região periapical, a localização destes campos foi padronizada em três orientações ao redor do ápice radicular: 
na região correspondente ao centro do canal e a 45 graus do centro do canal para a direita e para a esquerda. Os dados obtidos foram transformados em porcentagem em relação ao número total de células e analisados por meio do teste Qui quadrado $(a=0,05)$.

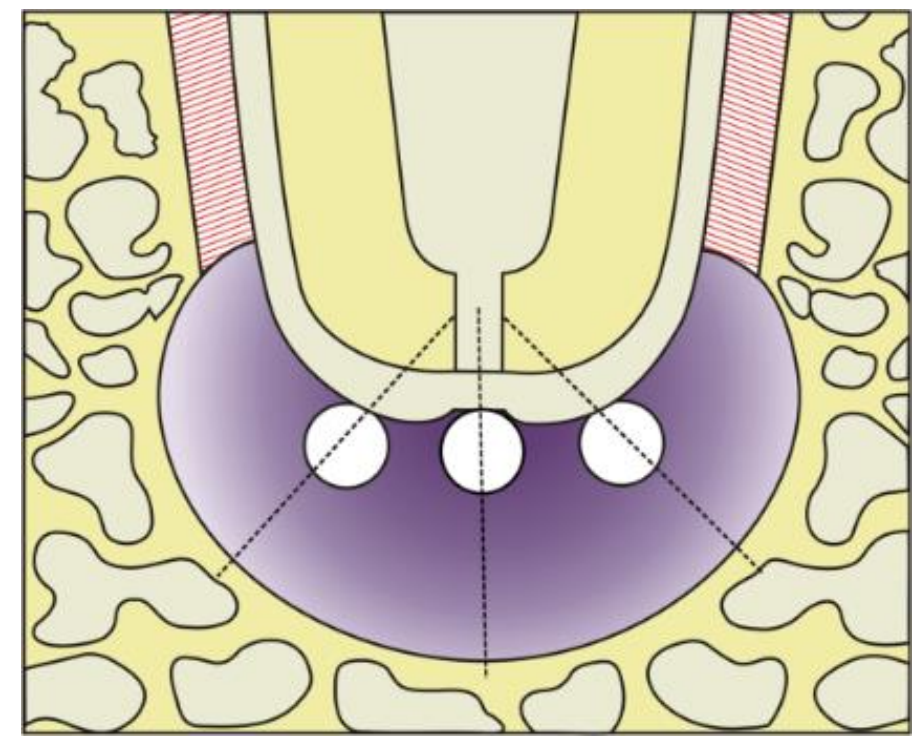

Figura 1. Representação esquemática dos campos de contagem das células inflamatórias e células marcadas positivamente para COX-2 na região periapical (40x).

\section{Imunohistoquímica}

Com o objetivo de localizar as células inflamatórias marcadas para a enzima COX-2, foi realizado ensaio de imunohistoquímica em lâminas referentes aos períodos de 7 , 14,21 e 28 dias.

As lâminas foram desparafinizadas, hidratadas em série descrecente de álcoois e mantidas em salina fosfatada tamponada (PBS). A seguir a peroxidase endógena foi bloqueada com peróxido de hidrogênio a 1,5 \% diluído em metanol por 30 minutos. As lâminas foram lavadas em PBS por 5 minutos $(2 \times)$ e submetidas à recuperação dos epítopos antigênicos utilizando solução tampão de citrato de sódio $(\mathrm{pH} 6,0)$ aquecido a $93^{\circ} \mathrm{C}$ por 15 minutos. A seguir, foram lavadas em PBS por 5 minutos $(2 \times)$ e os sítios de ligação nãoespecífica foram bloqueados com albumina de soro bovino (Sigma) a 1\% por 60 minutos. Os tecidos foram incubados com o anticorpo primário para COX-2 (sc-1746, Santa Cruz Biotechnology, Santa Cruz, EUA). A seguir as lâminas foram lavadas e incubadas com o anticorpo secundário anti-cabra biotinilado por 1 hora (Donkey anti-goat IgG, Biocare Medical, Concord, EUA), lavadas em PBS, e incubadas com estraptavidina conjugada à horseradish peroxidase (4plus Streptavidin-HRP, Biocare Medical) por 20 minutos. 3,3'Diaminobenzidina (DAB 500 Chromogen System, Biocare Medical) foi utilizado como substrato 
enzimático por 5 minutos e a seguir as lâminas foram lavadas em PBS, contra-coradas com hematoxilina de Harris por 15 segundos, lavadas com água destilada, desidratadas em concentrações crescentes de álcool e montadas em Permount ${ }^{\circledR}$. Lâminas-controle foram utilizadas para testar a especificidade da imunomarcação nas quais foi omitido o anticorpo primário e as lâminas foram incubadas com imunoglobulinas (IgG) obtidas da mesma espécie animal na qual o anticorpo primário correspondente foi produzido (Normal Goat IgG, Calbiochem).

As células presentes no tecido pulpar radicular, nas regiões cervical, média e apical foram agrupadas de acordo com suas características morfológicas em células inflamatórias polimorfonucleadas, células inflamatórias mononucleadas e fibroblastos. 0 número de células foi estimado em 3 campos representativos de cada corte, sendo utilizados 3 cortes por espécime, no aumento de 40× (Figura 1). Para avaliação da região periapical, a localização destes campos foi padronizada em três orientações ao redor do ápice radicular: na região correspondente ao centro do canal e a 45 graus do centro do canal para a direita e para a esquerda. Os dados obtidos foram transformados em porcentagem em relação ao número total de células e analisados por meio do teste Qui quadrado $(a=0,05)$. 
Resultados 



\section{RESULTADOS}

\section{A inoculação de LPS na câmara pulpar induz a expressão de Ptgš e dos receptores para PGE $_{2}$ (Ptger1, Ptger3 e Ptger4) in vivo}

Analisando o gráfico referente a expressão do gene Ptgs2, que codifica a enzima COX-2, observamos que a expressão do RNAm foi induzida, principalmente no período de 14 dias, após a inoculação de LPS nos canais radiculares (Figura 2).

\section{Ptgs2}

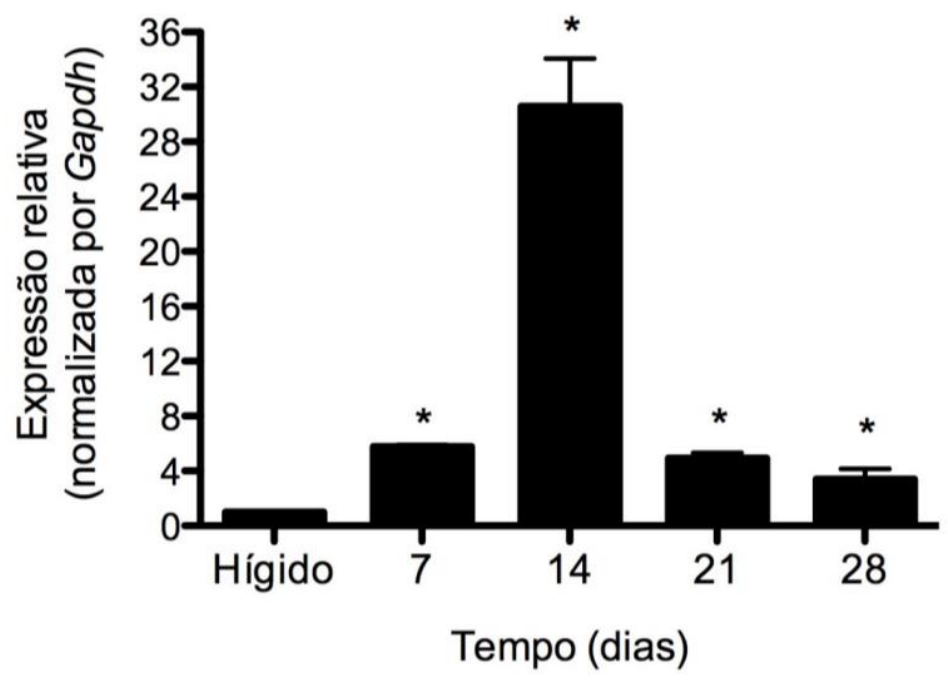

Figura 2. Expressão relativa do gene Ptgs2, que codifica a enzima COX-2, aos 7, 14, 21 e 28 dias após inoculação de LPS em dentes de camundongos. ${ }^{*} p<0,05$ comparado com o grupo controle (dente hígido).

Aos 14 dias foi observado o pico da expressão do gene Ptgs2, responsável pela codificação da enzima COX-2. Assim, neste período foi investigada a expressão dos receptores Ptger1, Ptger2, Ptger3 e Ptger4, para prostaglandina E2 $\left(\mathrm{PGE}_{2}\right)$, nos tecidos obtidos após inoculação de LPS na câmara pulpar. Foi observado um aumento na expressão dos receptores Ptger1, Ptger3 e Ptger4 após a inoculação de LPS, quando comparados ao grupo controle. A expressão do receptor Ptger2, por outro lado, manteve-se semelhante ao grupo controle (Figura 3). 


\section{Receptores para $\mathrm{PGE}_{2}$}

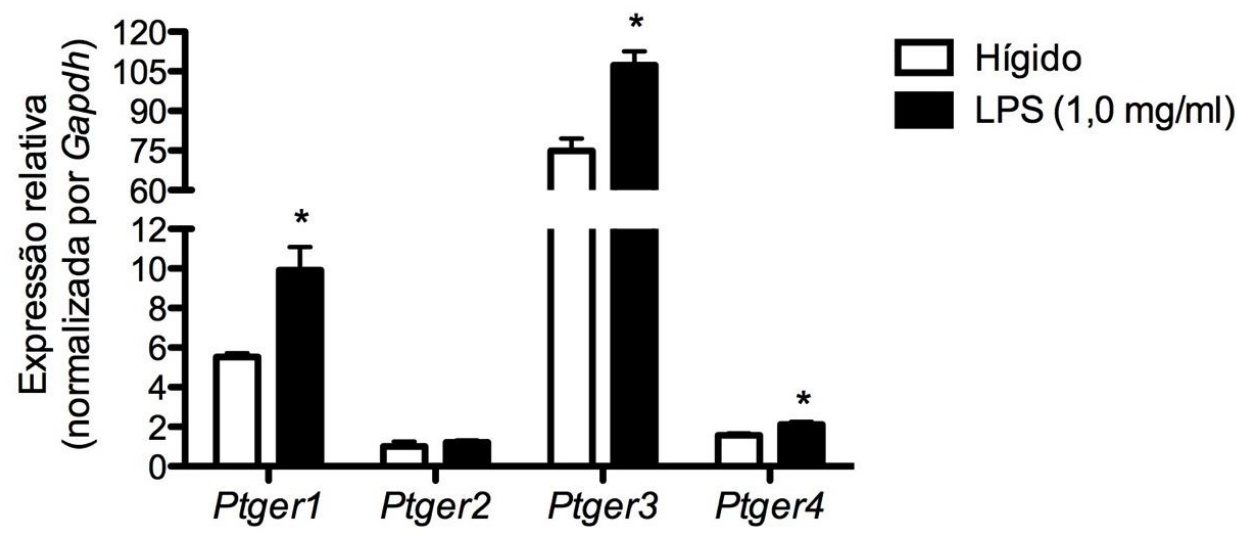

Figura 3. Expressão relativa dos receptores Ptger1, Ptger2, Ptger3 e Ptger4 para $\mathrm{PGE}_{2}$ durante o período experimental de 14 dias; $* p<0,05$ comparado com o grupo controle (dente hígido).

\section{LPS modula in vivo a expressão de genes que codificam os mediadores da osteoclastogênese RANK, RANKL e OPG}

Previamente à inoculação de LPS na câmara pulpar e tratamento com Indometacina e Celecoxibe, os animais foram pesados, e ao final dos períodos experimentais foi realizada uma nova pesagem para posterior comparação. A administração de Veículo, Indometacina ou Celecoxibe não influenciaram no ganho de peso dos animais (Figura 4).

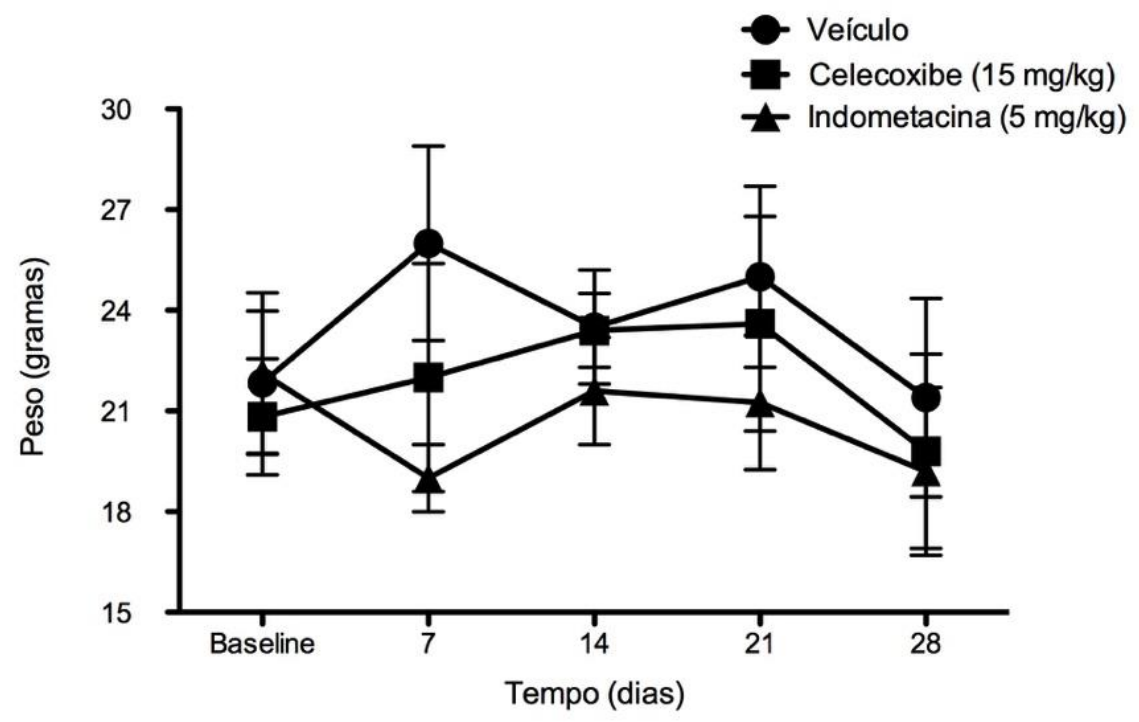

Figura 4. Representação gráfica do peso em função do tempo, após a administração de Veículo, Indometacina e Celecoxibe em camundongos, durante o decorrer de todo período experimental. ${ }^{*} p<0,05$ comparado com o grupo controle (veículo). 
A expressão de Tnfrsf11a não foi alterada pela inoculação de LPS na câmara pulpar durante todo período experimental $(p>0,05)$. A expressão de Tnfsf11 aumentou aos 7 dias $(p<0,05)$, diminuindo aos 14 dias $(p>0.05)$, aumentando novamente aos 21 dias ( $p$ $<0,05)$, atingindo concentração semelhante ao controle aos 28 dias $(p>0,05)$. Tnfrsf11b apresentou expressão aumentada aos 7 dias $(p<0,05)$, sem modulação após esse período $(p>0,05)$.

\section{Indometacina e Celecoxibe, inibidores não-seletivo e seletivo de COX-2,} respectivamente, modulam diferencialmente a expressão dos genes Tnfrsf11a, Tnfsf11 e Tnfrsf11b

O tratamento com Indometacina, um inibidor não seletivo de COX-2, não alterou a expressão de RNAm para Tnfrsf11a aos 7, 14 e 21 dias quando comparados ao grupo LPS sem tratamento $(p>0,05)$. Aos 28 dias houve um aumento exacerbado na expressão de Tnfrsf11a $(p<0,05)$. A expressão de Tnfsf11 foi reduzida aos 7 e 21 dias quando comparada ao grupo LPS $(p<0,05)$, porém foi elevada aos 14 e 28 dias $(p<0,05)$. A administração de Indometacina inibiou a expressão de Tnfrsf11b aos 7 e 28 dias, porém estimulou a expressão aos 14 dias $(p<0,05)$, quando comparada ao grupo LPS $(p<0,05)$.

O tratamento com Celecoxibe, um inibidor seletivo de COX-2 não alterou a expressão de Tnfrsf11a ao longo dos 28 dias de tratamento $(p>0,05)$. Houve estimulo a expressão de RNAm para Tnfsf11 aos 14 e 28 dias $(p<0,05)$ sem modulação da expressão aos 7 e 21 dias $(p>0,05)$. Tnfrsf11b não foi alterado pelo tratamento com Celecoxibe (Figura 5). 


\section{Tnfrsf11a}

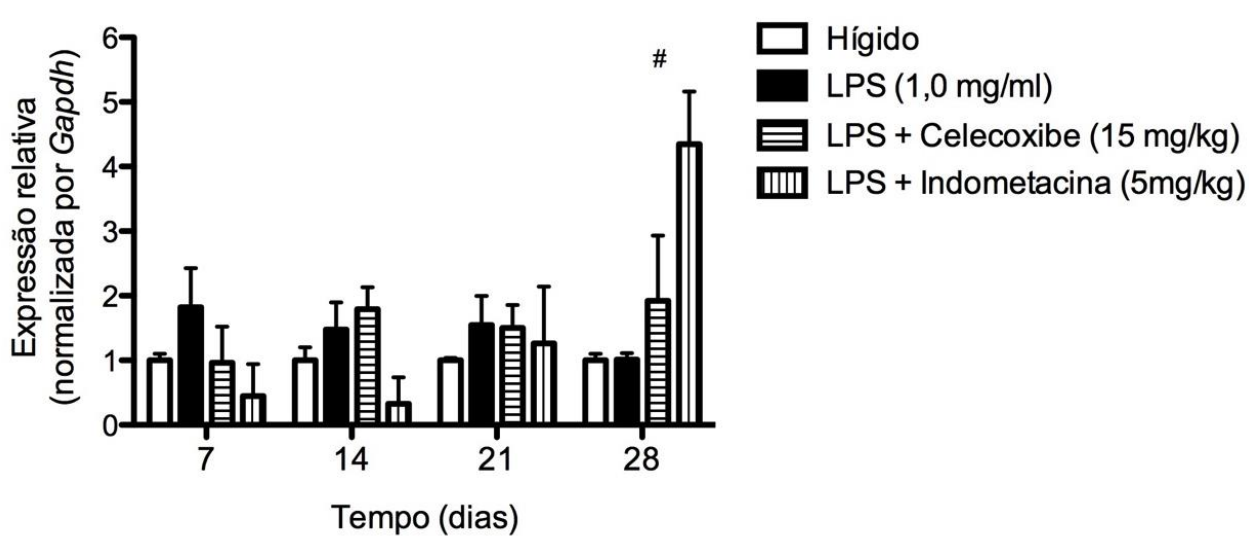

Tnfsf11

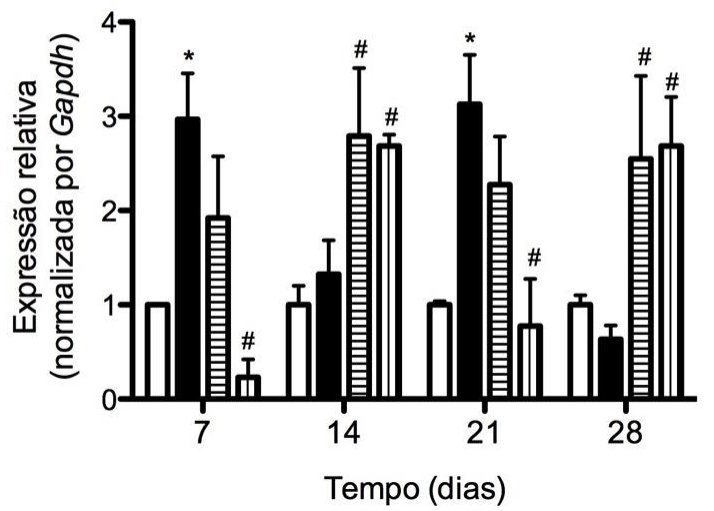

$$
\begin{aligned}
& \square \text { Hígido } \\
& \text { LPS (1,0 mg/ml) } \\
& \equiv \text { LPS + Celecoxibe ( } 15 \mathrm{mg} / \mathrm{kg}) \\
& \text { एIII LPS + Indometacina }(5 \mathrm{mg} / \mathrm{kg})
\end{aligned}
$$

\section{Tnfrsf11b}

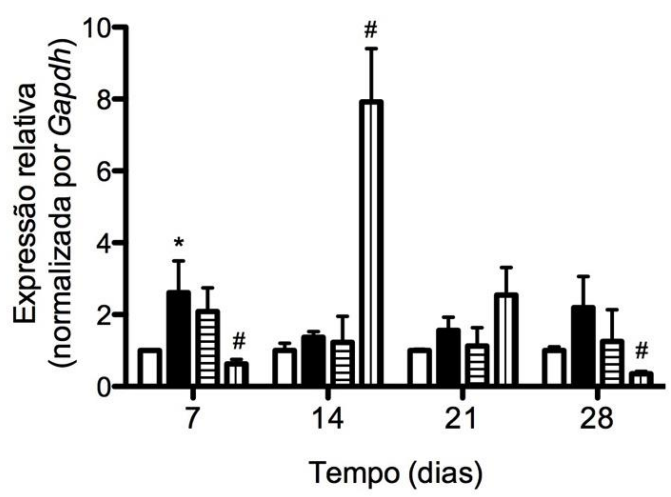

$$
\begin{aligned}
& \square \text { Hígido } \\
& \text { LPS (1,0 mg/ml) } \\
& \hline \text { LPS + Celecoxibe (15 mg/kg) } \\
& \square \text { LPS + Indometacina }(5 \mathrm{mg} / \mathrm{kg})
\end{aligned}
$$

Figura 5. Expressão relativa dos genes Tnfrsf11a, Tnfsf11 e Tnfrsf11b que codificam os receptores RANK, RANKL e OPG, respectivamente, aos 7, 14, 21 e 28 dias. Após inoculação de LPS, com administração diária de Indometacina e com a administração diária de Celecoxibe, nos canais radiculares de dentes de camundongos. ${ }^{*} p<0,05$ comparado com o grupo controle (veículo); ${ }^{\#} p<0,05$ comparado com 0 grupo LPS. 


\section{Mensuração da lesão periapical após inoculação de LPS e após administração de Indometacina ou Celecoxibe}

As lâminas submetidas à coloração por hematoxilina e eosina foram observadas em microscópio de luz convencional, no aumento de 10x, para mensuração da extensão da área das lesões periapicais em $\mathrm{mm}^{2}$, nos diferentes períodos de tempo (Figura 6). Durante os períodos experimentais de 7, 14 e 21 dias, os grupos de dentes nos quais foi inoculado LPS seguido pela administração de Indometacina ou Celecoxibe pode-se observar que não houve diferença estatisticamente significante $(p>0,05)$ no tamanho da lesão periapical quando comparado ao grupo em que foi apenas exposto ao LPS. A análise estatística realizada por meio do teste ANOVA de duas vias com pós-teste de Bonferroni, demonstrou diferença estatisticamente significante durante o período experimental de 28 dias, onde pode-se observar que apenas o grupo de dentes nos quais foi inoculado LPS com administração de Indometacina, apresentou um aumento estatisticamente significante $(p<$ $0,05)$ no tamanho da lesão periapical, quando comparado ao grupo em que apenas o LPS foi inoculado e no grupo em que foi inoculado o LPS com administração de Celecoxibe. Assim, pode-se observar que não houve interferência em relação a presença de reabsorção óssea na região periapical, em dentes com inoculação de LPS e administração dos medicamentos Celecoxibe ou Indometacina, durante todos os períodos experimentais estabelecidos, quando comparados ao grupo em que apenas o LPS foi inoculado. Exceto, durante o período de 28 dias, em animais em que o LPS foi inoculado e administrado Indometacina, onde foi observado um aumento estatisticamente significante da lesão periapical $(p<0,05)$.

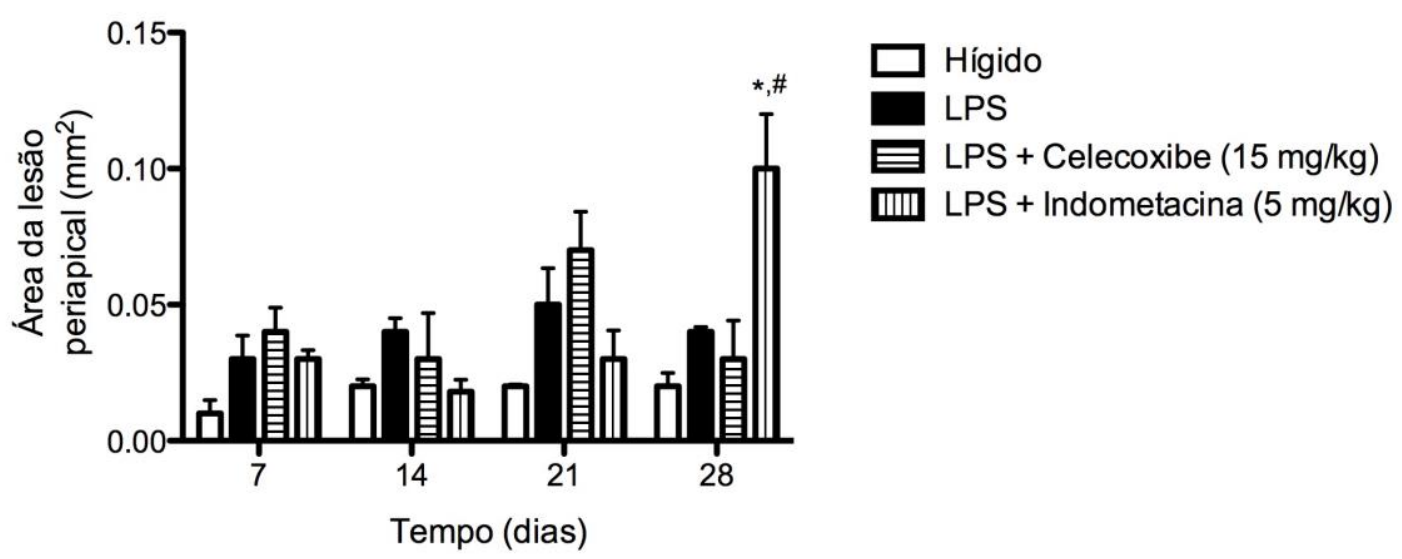

Figura 6. Representação gráfica da mensuração das áreas da lesão periapical em $\mathrm{mm}^{2}$ nos grupos: dentes hígidos (controle), dentes com inoculação de LPS, dentes com inoculação de LPS e administração de Celecoxibe e dentes com inoculação de LPS e administração de Indometacina, nos períodos experimentais de 7, 14, 21 e 28 dias. * $p<0,05$ comparado ao grupo LPS; ${ }^{*} p<0,05$ comparado ao grupo LPS + Celecoxibe. 


\section{Quantificação de células inflamatórias, mononucleadas e polimorfonucleadas, no tecido pulpar nos diferentes períodos experimentais}

As figuras 7, 8, 9 e 10 representam os dados obtidos nos diferentes períodos experimentais de $7,14,21$ e 28 dias, com relação ao percentual do número de células inflamatórias presentes o tecido pulpar, nos grupos de dentes hígidos, com inoculação de LPS, com inoculação de LPS e administração de Celecoxibe e inoculação de LPS e administração de Indometacina, respectivamente.

A figura 7, representa os dados obtidos durante o período experimental de 7 dias, onde foi comparado o percentual total de células inflamatórias, mononucleadas e polimorfonucleadas. No grupo de dentes hígidos observou-se um menor percentual de células inflamatórias, estatisticamente significante quando comparado ao grupo com inoculação de LPS $(p<0,05)$. Também foi observado um aumento estatisticamente significante no percentual de células inflamatórias no grupo onde foi realizada a inoculação de LPS com administração de Indometacina quando comparado ao grupo onde apenas a inoculação de LPS foi realizada $(p<0,05)$. Não foi observada diferença estatisticamente significativa entre o percentual de células inflamatórias, quando comparamos os grupos com inoculação de LPS e inoculação de LPS com administração de Celecoxibe $(p>0,05)$. 0 mesmo também pode ser observado entre os grupos em que houve inoculação de LPS e administração de Indometacina e inoculação de LPS e administração de Celecoxibe ( $p>$ $0,05)$.

A figura 7 também ilustra a comparação do percentual de células mononucleadas na região do tecido pulpar, entre os grupos de dentes hígidos, com inoculação de LPS, com inoculação de LPS e administração de Celecoxibe e inoculação de LPS e administração de Indometacina, respectivamente, durante o período de 7 dias. Foi observado diferença estatisticamente significante quando comparamos o grupo em que houve apenas a inoculação de LPS com o grupo em que além da inoculação de LPS foi administrado Indometacina $(p<0,05)$, mostrando um aumento do percentual de células mononucleadas neste último grupo. Também pode ser observado um aumento estatisticamente significante no percentual de células mononucleadas no grupo em que foi inoculado o LPS e administrado Indometacina, quando comparado ao grupo em que foi inoculado o LPS e administrado Celecoxibe $(p<0,05)$. Entre os grupos de dentes hígidos e com a inoculação de LPS, não houve diferença estatisticamente significante em relação ao percentual de células mononucleadas $(p>0,05)$. O mesmo também pode ser observado entre os grupos que houve inoculação de LPS e administração de Celecoxibe e inoculação de LPS e administração de Indometacina $(p>0,05)$. 
Ainda em relação ao período de 7 dias, podemos observar na figura 7 a comparação no percentual de células polimorfonucleadas entre os mesmos grupos mencionados anteriormente. Foi observada diferença estatisticamente significante quando comparamos o grupo de dentes hígidos com o grupo em que houve apenas inoculação de LPS $(p<0,05)$, com o aumento no percentual de células polimorfonucleadas neste último grupo. Entre o grupo em que houve apenas a inoculação de LPS com o grupo em que além da inoculação de LPS foi administrado Indometacina, também foi observada uma diferença estatisticamente significante $(p<0,05)$, mostrando uma diminuição do percentual de células polimorfonucleadas neste último grupo. Um aumento estatisticamente significante no percentual de células polimorfonucleadas no grupo em que foi inoculado o LPS e administrado Celecoxibe também foi observado $(p<0,05)$, quando comparado ao grupo em que foi inoculado o LPS e administrado Indometacina. Entre os grupos com a inoculação de apenas LPS e inoculação de LPS com administração de Celecoxibe, não houve diferença estatisticamente significante em relação ao percentual de células polimorfonucleadas ( $p>$ $0,05)$.

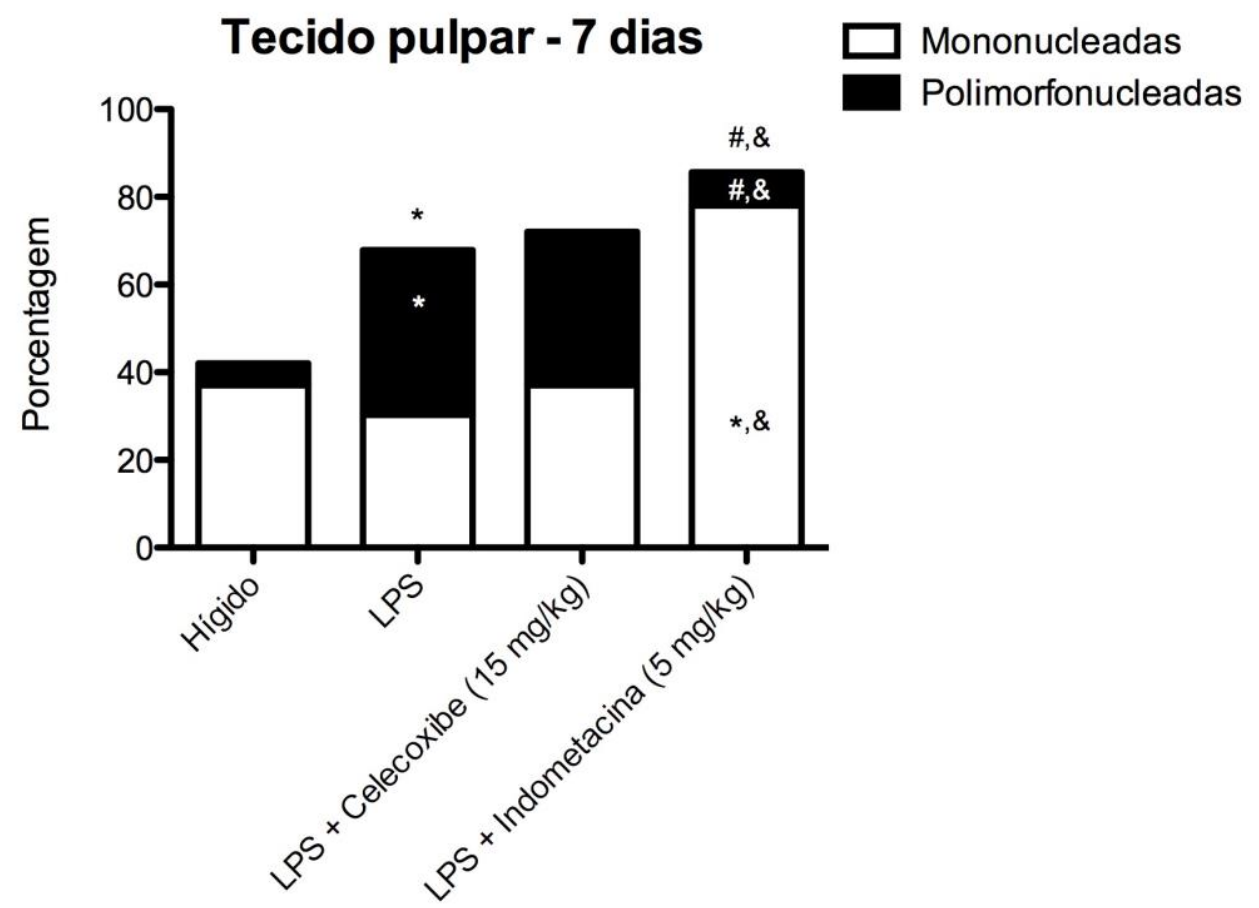

Figura 7. Representação gráfica da comparação dos resultados obtidos após contagem do número de células inflamatórias no período experimental de 7 dias, na região do tecido pulpar, nos grupos: dentes hígidos, dentes com inoculação de LPS, dentes com inoculação de LPS e administração de Celecoxibe e dentes com inoculação de LPS e administração de Indometacina. * $p<0,05$ comparado ao grupo de dentes hígidos; ${ }^{*} p<0,05$ comparado ao grupo com inoculação de LPS; ${ }^{\&} p<0,05$ comparado os grupos LPS + Indometacina em relação ao grupo LPS + Celecoxibe. 
A figura 8 representa os dados obtidos durante o período experimental de 14 dias, onde foi comparado o percentual total de células inflamatórias, mononucleadas e polimorfonucleadas. Não foi observado diferença estatisticamente significante entre o percentual de células inflamatórias, entre os grupos de dentes hígidos, grupo com inoculação de LPS, grupo com inoculação de LPS e administração de Celecoxibe e grupo com inoculação de LPS e administração de Indometacina $(p>0,05)$.

Na figura 8 também pode ser observado a comparação do percentual de células mononucleadas entre os grupos mencionados, durante o período de 14 dias. Apenas foi observada diferença estatisticamente significante quando comparamos o grupo em que houve a inoculação de LPS com o grupo em que além da inoculação de LPS foi administrado Indometacina, mostrando um aumento do percentual de células mononucleadas neste último grupo $(p<0,05)$. Não foi observado diferença estatisticamente significante no percentual de células mononucleadas quando comparados os demais grupos $(p>0,05)$.

Ainda em relação ao período de 14 dias, podemos observar na figura 8 a comparação no percentual de células polimorfonucleadas entre os grupos descritos. Foi observado diferença estatisticamente significante quando comparamos o grupo de dentes hígidos com o grupo em que houve apenas inoculação de LPS $(p<0,05)$, com o aumento no percentual de células polimorfonucleadas neste último grupo. Entre o grupo em que houve apenas a inoculação de LPS com o grupo em que além da inoculação de LPS foi administrado Celecoxibe, foi observada uma diminuição no percentual de células polimorfonucleadas neste último grupo $(p<0,05)$. Por outro lado, entre o grupo em que apenas o LPS foi inoculado comparado com o grupo em que além da inoculação de LPS foi administrado Indometacina, houve uma diferença estatisticamente significante, mostrando uma diminuição do percentual de células polimorfonucleadas neste último grupo $(p<0,05)$. Em relação a comparação do grupo com a inoculação de LPS e administração de Indometacina e o grupo com a inoculação de LPS com administração de Celecoxibe, não houve diferença estatisticamente significante em relação ao percentual de células polimorfonucleadas $(p>0,05)$. 


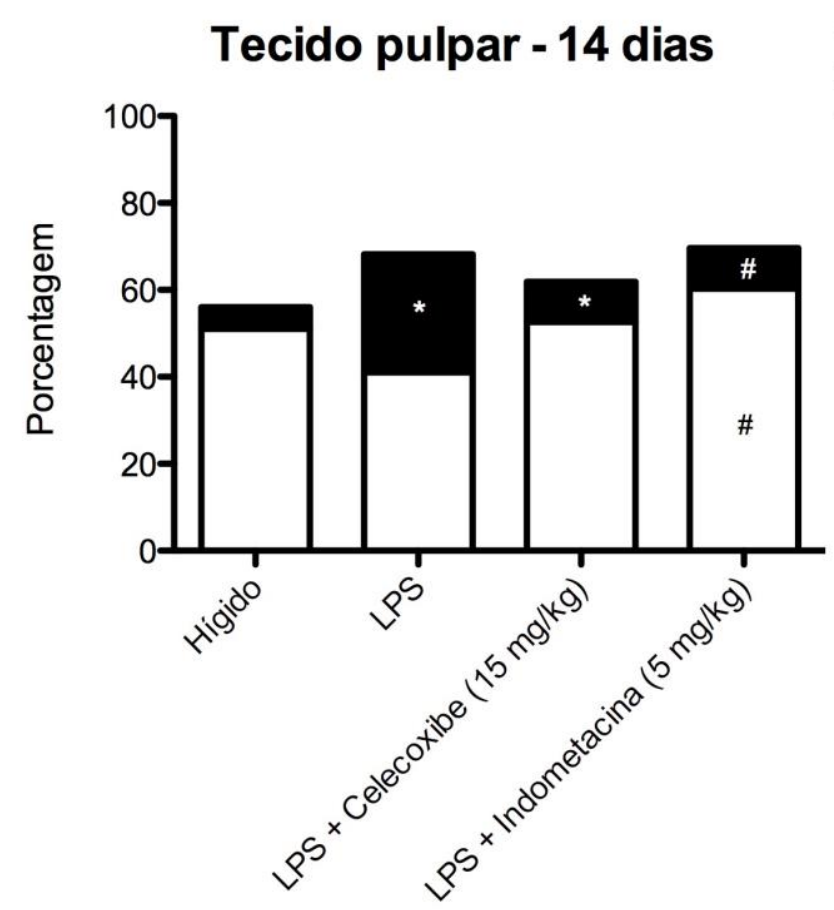

Figura 8. Representação gráfica da comparação dos resultados obtidos após contagem do número de células inflamatórias no período experimental de 14 dias, na região do tecido pulpar, nos grupos: dentes hígidos, dentes com inoculação de LPS, dentes com inoculação de LPS e administração de Celecoxibe e dentes com inoculação de LPS e administração de Indometacina. * $p<0,05$ comparado ao grupo de dentes hígidos; ${ }^{\#} p<0,05$ comparado ao grupo com inoculação de LPS; ${ }^{\&} p<0,05$ comparado os grupos LPS + Indometacina em relação ao grupo LPS + Celecoxibe.

A figura 9 representa os dados obtidos durante o período experimental de 21 dias, onde foi comparado o percentual total de células inflamatórias, mononucleadas e polimorfonucleadas. Foi observado no grupo de dentes hígidos um menor percentual de células inflamatórias, estatisticamente significante quando comparado ao grupo com inoculação de LPS $(p<0,05)$. Não foi observado diferença estatisticamente significativa entre o percentual de células inflamatórias quando comparamos os grupos com inoculação de LPS e inoculação de LPS com administração de Celecoxibe $(p>0,05)$. O mesmo também pode ser observado entre os grupos onde foi realizada a inoculação de LPS com administração de Indometacina quando comparado ao grupo onde apenas a inoculação de LPS foi realizada $(p>0,05)$. Entre os grupos em que houve inoculação de LPS e administração de Indometacina e inoculação de LPS e administração de Celecoxibe também não foi observado diferença estatisticamente significante entre o percentual de células inflamatórias $(p>0,05)$.

A figura 9 também ilustra a comparação do percentual de células mononucleadas entre os grupos mencionados, durante o período de 21 dias. Comparando os grupos de dentes hígidos e o grupo com a inoculação de LPS, houve um aumento estatisticamente significante em relação ao percentual de células mononucleadas no último 
grupo $(p<0,05)$. Foi observado diferença estatisticamente significante quando comparamos o grupo em que houve apenas a inoculação de LPS com o grupo em que além da inoculação de LPS foi administrado Celecoxibe, mostrando um aumento do percentual de células mononucleadas neste último grupo $(p<0,05)$. Também foi observado um aumento estatisticamente significante no percentual de células mononucleadas no grupo em que foi inoculado o LPS e administrado Indometacina, quando comparado ao grupo em que apenas foi inoculado o LPS $(p<0,05)$. O mesmo também pode ser observado entre os grupos que houve inoculação de LPS e administração de Celecoxibe e inoculação de LPS e administração de Indometacina, com um aumento no percentual de células mononucleadas no último grupo $(p<0,05)$.

Ainda em relação ao período de 21 dias, podemos observar na figura 9 a comparação no percentual de células polimorfonucleadas entre os grupos descritos. Foi observado diferença estatisticamente significante entre todos os grupos mencionados anteriormente $(p<0,05)$, exceto entre os grupos que houve inoculação de LPS e administração de Celecoxibe e inoculação de LPS e administração de Indometacina $(p>$ 0,05). Quando comparamos o grupo de dentes hígidos com o grupo em que houve apenas inoculação de LPS, podemos observar um aumento no percentual de células polimorfonucleadas neste último grupo $(p<0,05)$. Entre o grupo em que houve apenas a inoculação de LPS com o grupo em que além da inoculação de LPS foi administrado Celecoxibe, também foi observada uma diferença estatisticamente significante, mostrando uma diminuição do percentual de células polimorfonucleadas neste último grupo $(p<0,05)$. Em relação ao grupo em que foi inoculado o LPS e o grupo em que foi inoculado LPS e administrado Indometacina, foi observado uma diminuição estatisticamente significante no percentual de células polimorfonucleadas quando a administração de Indometacina foi realizada $(p<0,05)$. 


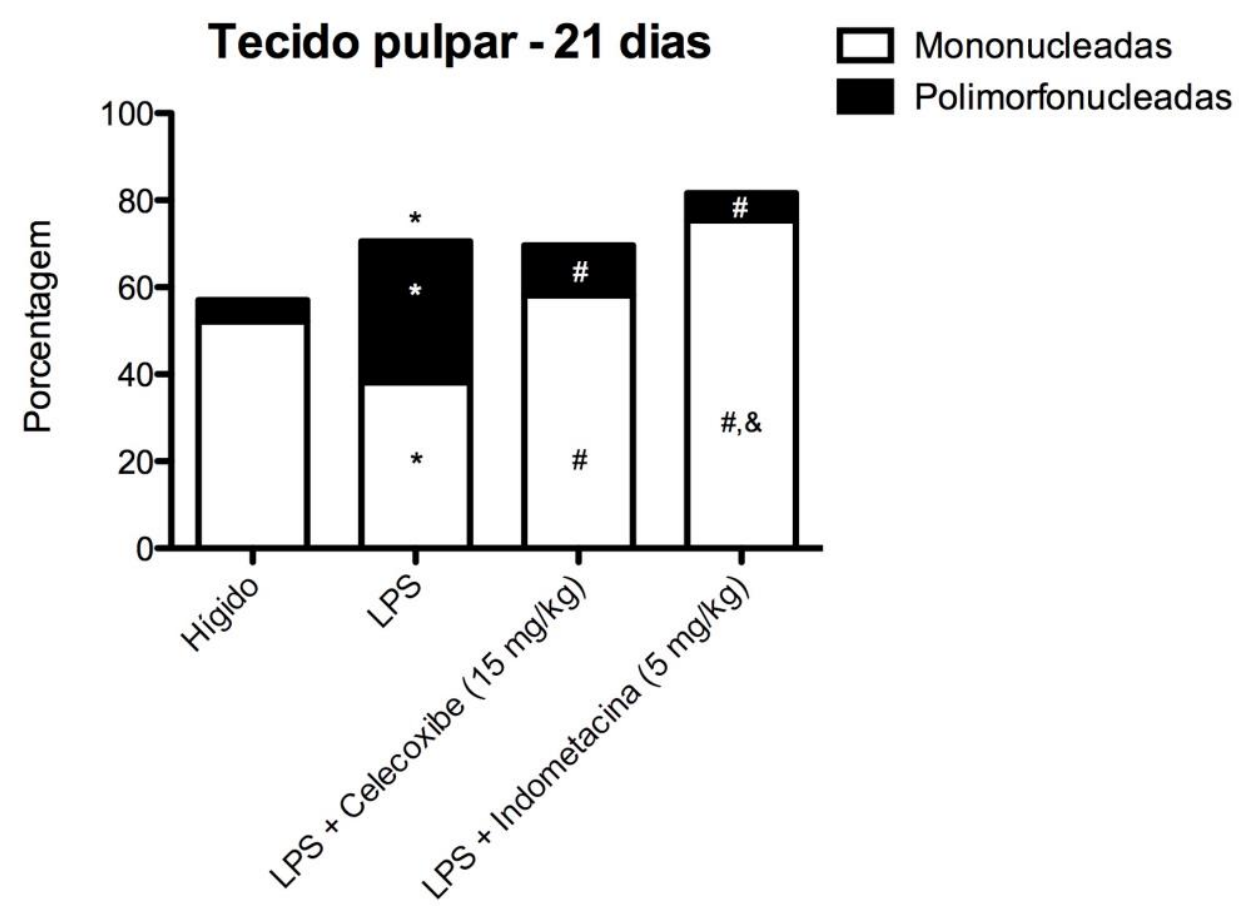

Figura 9. Representação gráfica da comparação dos resultados obtidos após contagem do número de células inflamatórias no período experimental de 21 dias, na região do tecido pulpar, nos grupos: dentes hígidos (controle negativo), dentes com inoculação de LPS (controle positivo), dentes com inoculação de LPS e administração de Celecoxibe e dentes com inoculação de LPS e administração de Indometacina. * $p<0,05$ comparado ao grupo de dentes hígidos; ${ }^{*} p<0,05$ comparado ao grupo com inoculação de LPS; ${ }^{\&} p<0,05$ comparado os grupos LPS + Indometacina em relação ao grupo LPS + Celecoxibe.

A figura 10 representa os dados obtidos durante o período experimental de 28 dias, onde foi comparado o percentual total de células inflamatórias, mononucleadas e polimorfonucleadas. No grupo de dentes hígidos observou-se um menor percentual de células inflamatórias, estatisticamente significante quando comparado ao grupo com inoculação de LPS $(p<0,05)$. Não foi observada uma diferença estatisticamente significativa entre o percentual de células inflamatórias quando comparamos os demais grupos $(p>$ $0,05)$.

A figura 10 também ilustra a comparação do percentual de células mononucleadas entre os grupos de dentes hígidos, com inoculação de LPS, com inoculação de LPS e administração de Celecoxibe e inoculação de LPS e administração de Indometacina, respectivamente, durante o período de 28 dias. Foi observado diferença estatisticamente significante quando comparamos o grupo em que houve apenas a inoculação de LPS com o grupo em que além da inoculação de LPS foi administrado Celecoxibe $(p<0,05)$, mostrando um aumento do percentual de células mononucleadas neste último grupo. Também foi observado um aumento estatisticamente significante no percentual de células mononucleadas no grupo em que foi inoculado o LPS e administrado Indometacina, quando 
comparado ao grupo em que apenas o LPS foi inoculado $(p<0,05)$. Não houve diferença estatisticamente significante em relação ao percentual de células mononucleadas entre os grupos que houve inoculação de LPS e administração de Celecoxibe e inoculação de LPS e administração de Indometacina $(p>0,05)$.

Ainda em relação ao período de 28 dias, podemos observar na figura 10 a comparação no percentual de células polimorfonucleadas entre os grupos citados anteriormente, sendo observado diferença estatisticamente significante entre todos eles $(p<$ 0,05). Quando comparamos o grupo de dentes hígidos com o grupo em que houve apenas inoculação de LPS, observamos um aumento no percentual de células polimorfonucleadas neste último grupo $(p<0,05)$. Entre o grupo em que houve apenas a inoculação de LPS com o grupo em que além da inoculação de LPS foi administrado Celecoxibe, também foi observada uma diferença estatisticamente significante, mostrando uma diminuição do percentual de células polimorfonucleadas neste último $\operatorname{grupo}(p<0,05)$. Também foi observada uma diminuição estatisticamente significante no percentual de células polimorfonucleadas no grupo em que foi inoculado o LPS e administrado Indometacina, quando comparado ao grupo em que foi apenas inoculado o LPS $(p<0,05)$. Entre os grupos com a inoculação LPS e administração de Celecoxibe e inoculação de LPS com administração de Indometacina, houve um aumento estatisticamente significante em relação ao percentual de células polimorfonucleadas quando a Indometacina foi administrada $(p<0,05)$. 


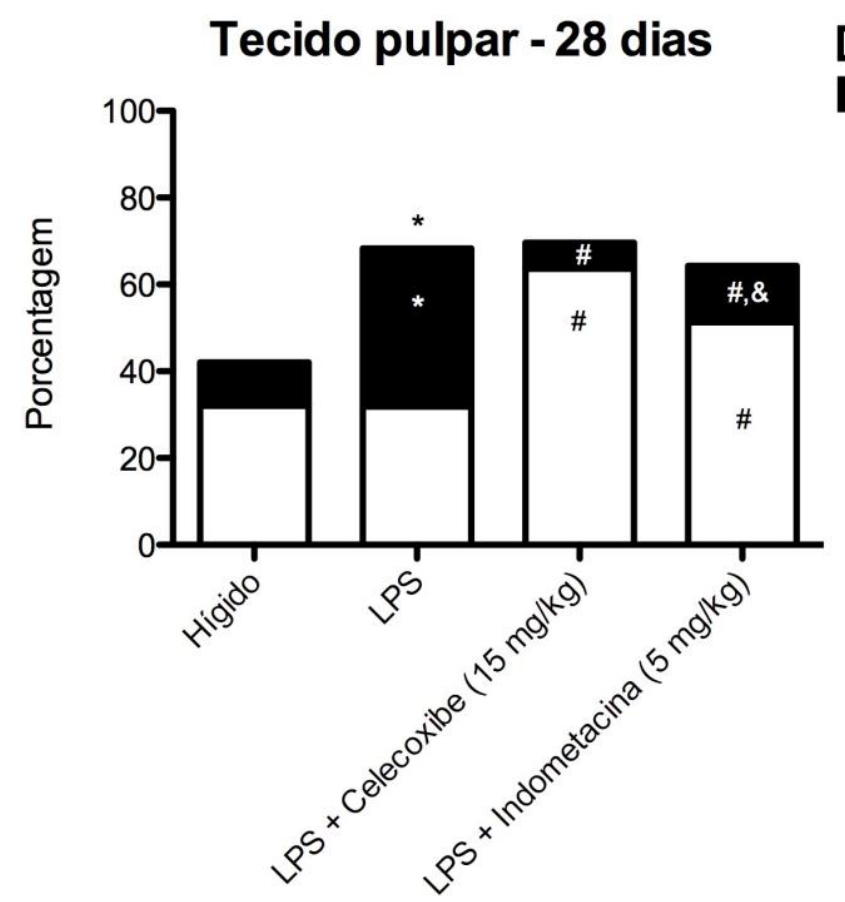

Figura 10. Representação gráfica da comparação dos resultados obtidos após contagem do número de células inflamatórias no período experimental de 28 dias, na região do tecido pulpar, nos grupos: dentes hígidos, dentes com inoculação de LPS, dentes com inoculação de LPS e administração de Celecoxibe e dentes com inoculação de LPS e administração de Indometacina. * $p<0,05$ comparado ao grupo de dentes hígidos; ${ }^{\#} p<0,05$ comparado ao grupo com inoculação de LPS; ${ }^{\&} p<0,05$ comparado os grupos LPS + Indometacina em relação ao grupo LPS + Celecoxibe.

\section{Quantificação de células inflamatórias, mononucleadas e polimorfonucleadas, na região do tecido periapical nos diferentes períodos experimentais}

As figuras $11,12,13$ e 14 representam os dados obtidos nos diferentes períodos experimentais de 7, 14, 21 e 28 dias, com relação ao percentual do número de células inflamatórias na região do tecido periapical, nos grupos de dentes hígidos, grupos com inoculação de LPS, grupos com inoculação de LPS e administração de Celecoxibe e grupos com inoculação de LPS e administração de Indometacina, respectivamente.

A figura 11, representa os dados obtidos durante o período experimental de 7 dias, onde foi comparado o percentual total de células inflamatórias, mononucleadas e polimorfonucleadas. No grupo de dentes hígidos, observou-se um menor percentual de células inflamatórias, estatisticamente significante quando comparado ao grupo com apenas a inoculação de LPS $(p<0,05)$. Um aumento estatisticamente significante no percentual de células inflamatórias no grupo onde foi realizada a inoculação de LPS com administração de Celecoxibe quando comparado ao grupo onde apenas a inoculação de LPS foi realizada 
também pode ser observado $(p<0,05)$. O grupo em que foi inoculado LPS e administrado Indometacina, apresentou um aumento de células inflamatórias estatisticamente significante quando comparado ao grupo em que apenas o LPS foi inoculado $(p<0,05)$. Não foi observado uma diferença estatisticamente significante entre o percentual de células inflamatórias quando comparamos os grupos com inoculação de LPS com administração de Celecoxibe e inoculação de LPS com administração de Indometacina $(p>0,05)$.

A figura 11 também ilustra a comparação do percentual de células mononucleadas entre os grupos mencionados, durante o período de 7 dias. Foi observado diferença estatisticamente significante quando comparamos o grupo em que houve apenas a inoculação de LPS com o grupo em que além da inoculação de LPS foi administrado Indometacina, mostrando um aumento do percentual de células mononucleadas neste último grupo $(p<0,05)$. Também foi observado um aumento estatisticamente significante no percentual de células mononucleadas no grupo em que foi inoculado o LPS e administrado Indometacina, quando comparado ao grupo em que foi inoculado o LPS e administrado Celecoxibe $(p<0,05)$. Entre os grupos de dentes hígidos e com a inoculação de LPS, não houve diferença estatisticamente significante em relação ao percentual de células mononucleadas $(p>0,05)$. O mesmo também pode ser observado entre os grupos em que houve apenas inoculação de LPS e inoculação de LPS com a administração de Celecoxibe ( $p$ $>0,05)$.

Ainda em relação ao período de 7 dias, podemos observar na figura 11 a comparação no percentual de células polimorfonucleadas entre os grupos já descritos. Foi observado diferença estatisticamente significante quando comparamos o grupo de dentes hígidos com o grupo em que houve apenas inoculação de LPS, com o aumento no percentual de células polimorfonucleadas neste último grupo $(p<0,05)$. Entre o grupo em que houve apenas a inoculação de LPS com o grupo em que além da inoculação de LPS foi administrado Indometacina, também foi observada uma diferença estatisticamente significante, mostrando uma diminuição do percentual de células polimorfonucleadas neste último grupo $(p<0,05)$. Foi observado um aumento estatisticamente significante no percentual de células polimorfonucleadas no grupo em que foi inoculado o LPS e administrado Celecoxibe, quando comparado ao grupo em que foi inoculado o LPS e administrado Indometacina $(p<0,05)$. Entre os grupos com a inoculação de apenas LPS e inoculação de LPS com administração de Celecoxibe, não houve diferença estatisticamente significante em relação ao percentual de células polimorfonucleadas $(p>0,05)$. 


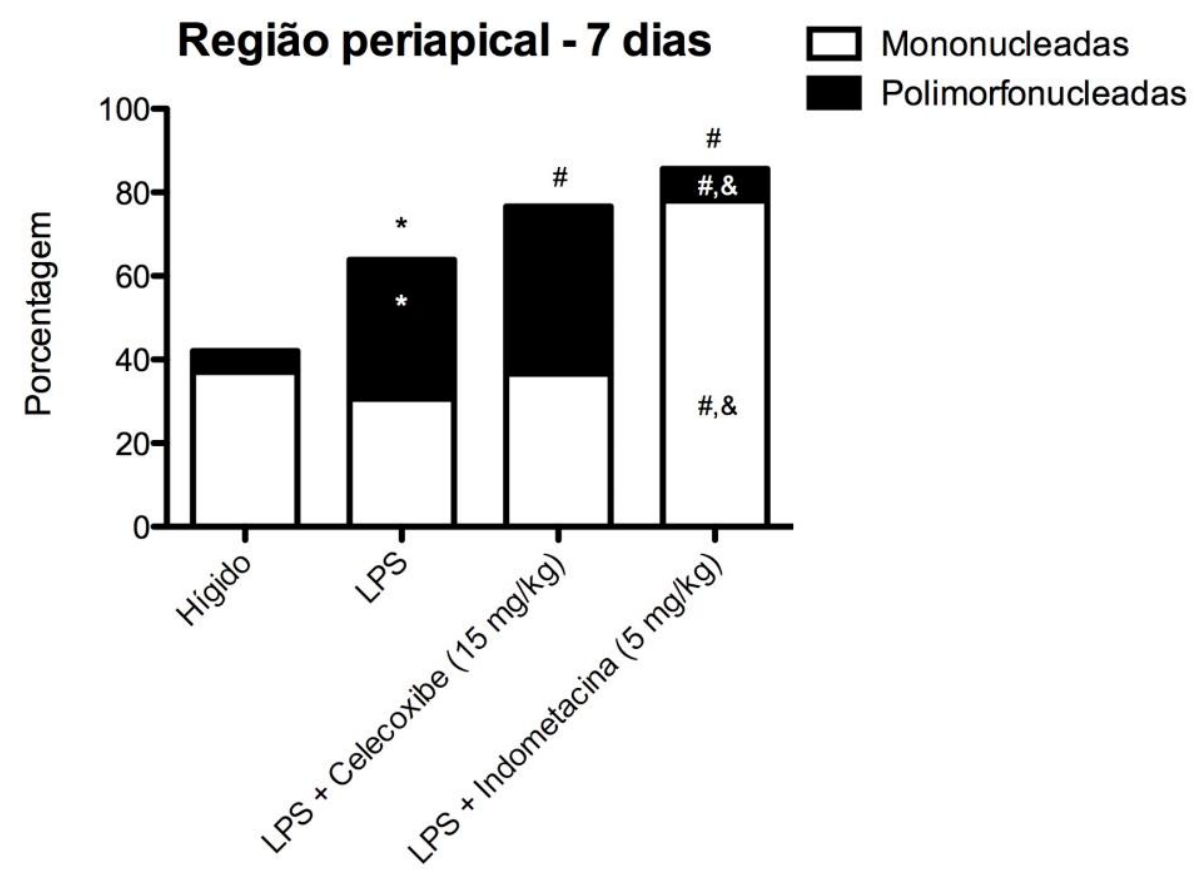

Figura 11. Representação gráfica da comparação dos resultados obtidos após contagem do número de células inflamatórias no período experimental de 7 dias, na região do tecido periapical, nos grupos: dentes hígidos, dentes com inoculação de LPS, dentes com inoculação de LPS e administração de Celecoxibe e dentes com inoculação de LPS e administração de Indometacina. $* p<0,05$ comparado ao grupo de dentes hígidos; ${ }^{\#} p<0,05$ comparado ao grupo com inoculação de LPS; ${ }^{\&} p<0,05$ comparado os grupos LPS + Indometacina em relação ao grupo LPS + Celecoxibe.

A figura 12, representa os dados obtidos durante o período experimental de 14 dias, onde foi comparado o percentual total de células inflamatórias, mononucleadas e polimorfonucleadas. Não foi observado diferença estatisticamente significante entre o percentual de células mononucleadas e polimorfonucleadas, entre os grupos de dentes hígidos, com inoculação de LPS, com inoculação de LPS e administração de Celecoxibe e inoculação de LPS e administração de Indometacina $(p>0,05)$.

Na figura 12 também pode ser observado a comparação do percentual de células mononucleadas entre os grupos mencionados, durante o período de 14 dias. Foi observada diferença estatisticamente significante quando comparamos o grupo em que houve apenas a inoculação de LPS com o grupo em que além da inoculação de LPS foi administrado Celecoxibe, mostrando um aumento do percentual de células mononucleadas neste último grupo $(p<0,05)$. Entre o grupo em que houve apenas a inoculação de LPS com o grupo em que além da inoculação de LPS foi administrado Indometacina, também foi observada um aumento estatisticamente significante no percentual de células mononucleadas neste último grupo $(p<0,05)$. Não havendo diferença estatisticamente significante no percentual de células mononucleadas nas comparações dos demais grupos ( $p$ $>0,05)$. 
Ainda em relação ao período de 14 dias, podemos observar na figura 12 a comparação no percentual de células polimorfonucleadas entre os grupos descritos. Foi observada diferença estatisticamente significante quando comparamos o grupo de dentes hígidos com o grupo em que houve apenas inoculação de LPS, com o aumento no percentual de células polimorfonucleadas neste último grupo $(p<0,05)$. Comparando o grupo em que houve apenas a inoculação de LPS com o grupo em que além da inoculação de LPS foi administrado Celecoxibe, foi observada uma diminuição no percentual de células polimorfonucleadas neste último grupo $(p<0,05)$. 0 mesmo pode ser observado entre 0 grupo em que apenas o LPS foi inoculado com o grupo em que além da inoculação de LPS foi administrado Indometacina $(p<0,05)$. Entre o grupo com a inoculação de LPS e administração de Indometacina e o grupo com a inoculação de LPS com administração de Celecoxibe, não houve diferença estatisticamente significante em relação ao percentual de células polimorfonucleadas $(p>0,05)$.

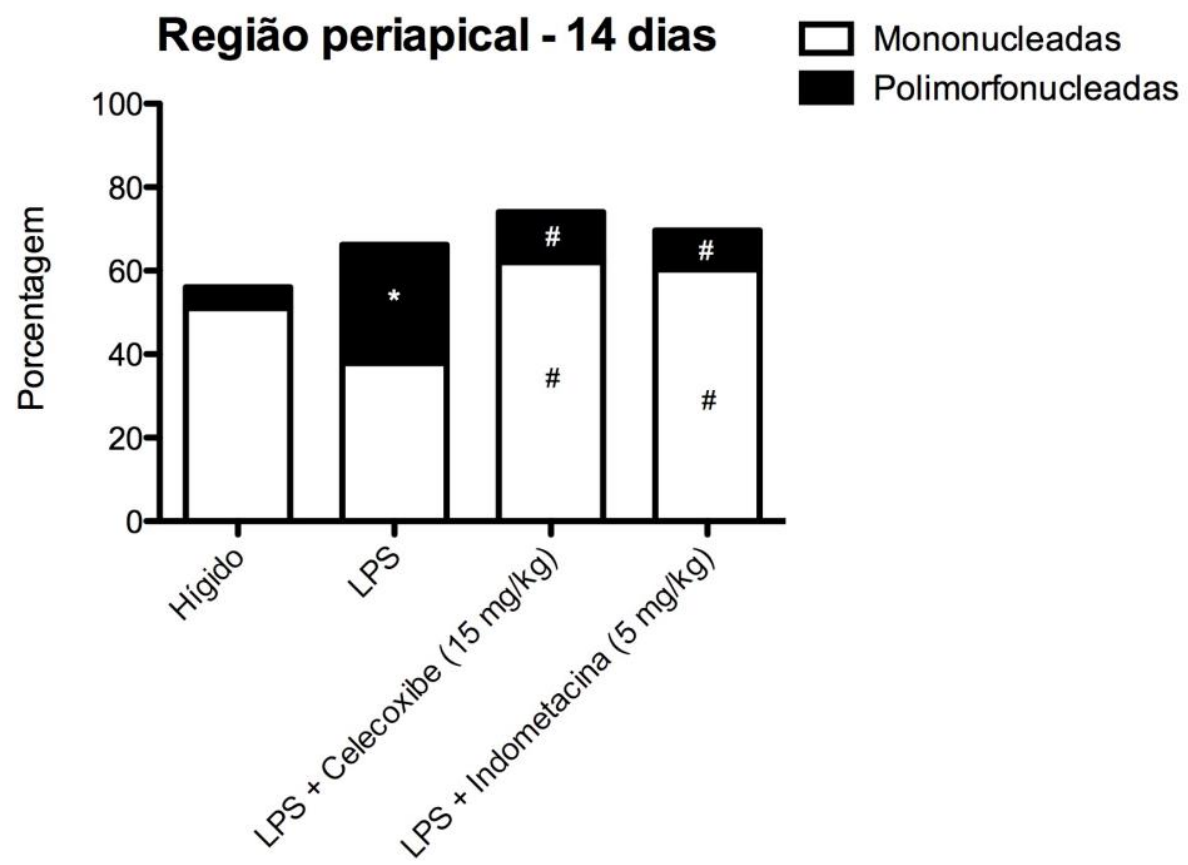

Figura 12. Representação gráfica da comparação dos resultados obtidos após contagem do número de células inflamatórias no período experimental de 14 dias, na região do tecido periapical, nos grupos: dentes hígidos, dentes com inoculação de LPS, dentes com inoculação de LPS e administração de Celecoxibe e dentes com inoculação de LPS e administração de Indometacina. * $p<0,05$ comparado ao grupo de dentes hígidos; ${ }^{\#} p<0,05$ comparado ao grupo com inoculação de LPS; ${ }^{\&} p<0,05$ comparado os grupos LPS + Indometacina em relação ao grupo LPS + Celecoxibe.

A figura 13, representa os dados obtidos durante o período experimental de 21 dias, onde foi comparado o percentual total de células inflamatórias, mononucleadas e polimorfonucleadas. Foi observado um aumento estatisticamente significante no percentual 
de células inflamatórias no grupo onde foi realizada a inoculação de LPS com administração de Indometacina quando comparado ao grupo onde apenas a inoculação de LPS foi realizada $(p<0,05)$. O grupo em que foi inoculado LPS e administrado Indometacina, apresentou um aumento no percentual de células inflamatórias estatisticamente significante quando comparado ao grupo em que o LPS foi inoculado com a administração do Celecoxibe $(p<$ $0,05)$. No grupo de dentes hígidos, não foi observado uma diferença estatisticamente significante no percentual de células inflamatórias quando comparado ao grupo com apenas a inoculação de LPS $(p>0,05)$. Também não foi observado uma diferença estatisticamente significante entre o percentual de células inflamatórias quando comparamos os grupos com apenas inoculação de LPS e inoculação de LPS com administração de Celecoxibe $(p>0,05)$.

A figura 13 também ilustra a comparação do percentual de células mononucleadas entre os grupos entre os grupos mencionados, durante o período de 21 dias. O grupo em que foi inoculado apenas o LPS apresentou um menor percentual de células mononucleadas quando comparado ao grupo de dentes hígidos $(p<0,05)$. Foi observado diferença estatisticamente significante quando comparamos o grupo em que houve apenas a inoculação de LPS com o grupo em que além da inoculação de LPS foi administrado Celecoxibe, mostrando um aumento do percentual de células mononucleadas neste último grupo $(p<0,05)$. O mesmo pode ser observado em relação ao grupo em que além da inoculação de LPS foi administrado Indometacina $(p<0,05)$. Também foi observado um aumento estatisticamente significante no percentual de células mononucleadas no grupo em que foi inoculado o LPS e administrado Indometacina, quando comparado ao grupo em que foi inoculado o LPS e administrado Celecoxibe $(p<0,05)$.

Ainda em relação ao período de 21 dias, podemos observar na figura 13 a comparação no percentual de células polimorfonucleadas entre os grupos já descritos. Foi observado diferença estatisticamente significante quando comparamos o grupo de dentes hígidos com o grupo em que houve apenas inoculação de LPS, com o aumento no percentual de células polimorfonucleadas neste último grupo $(p<0,05)$. Comparando o grupo em que houve apenas a inoculação de LPS com o grupo em que além da inoculação de LPS foi administrado Celecoxibe, também foi observada uma diferença estatisticamente significante, mostrando uma diminuição do percentual de células polimorfonucleadas neste último grupo $(p<0,05)$. Uma diminuição estatisticamente significante no percentual de células polimorfonucleadas no grupo em que foi inoculado o LPS e administrado Indometacina foi observada, quando comparado ao grupo em que apenas foi inoculado o LPS $(p<0,05)$. 0 grupo com a inoculação de LPS e administração de Celecoxibe apresentou um aumento estatisticamente significante em relação ao percentual de células polimorfonucleadas em relação ao grupo com inoculação de LPS e administração de Indometacina $(p<0,05)$. 


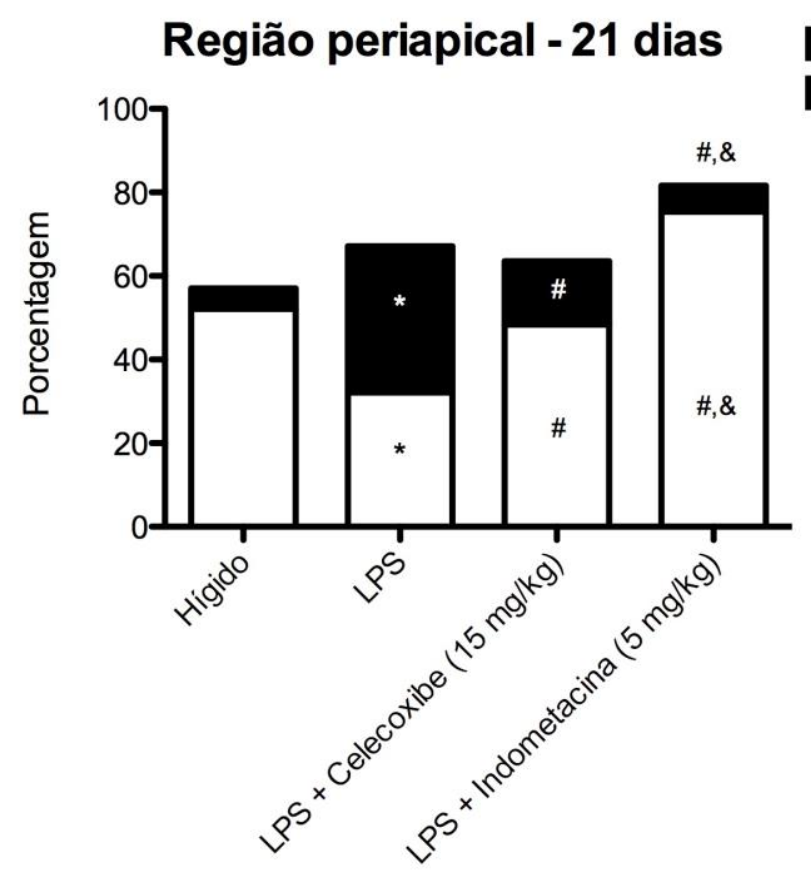

Figura 13. Representação gráfica da comparação dos resultados obtidos após contagem do número de células inflamatórias no período experimental de 21 dias, na região do tecido periapical, nos grupos: dentes hígidos, dentes com inoculação de LPS, dentes com inoculação de LPS e administração de Celecoxibe e dentes com inoculação de LPS e administração de Indometacina. * $p<0,05$ comparado ao grupo de dentes hígidos; ${ }^{*} p<0,05$ comparado ao grupo com inoculação de LPS; ${ }^{\&} p<0,05$ comparado os grupos LPS + Indometacina em relação ao grupo LPS + Celecoxibe.

A figura 14, representa os dados obtidos durante o período experimental de 28 dias, onde foi comparado o percentual total de células inflamatórias, mononucleadas e polimorfonucleadas. Observando o grupo de dentes hígidos podemos constatar um menor percentual de células inflamatórias, quando comparado ao grupo com inoculação de LPS ( $p$ $<0,05)$. Não foi observado uma diferença estatisticamente significativa entre o percentual de células inflamatórias quando comparados os demais grupos $(p>0,05)$.

A figura 14 também ilustra a comparação do percentual de células mononucleadas entre os grupos de dentes hígidos, com inoculação de LPS, com inoculação de LPS e administração de Celecoxibe e inoculação de LPS e administração de Indometacina durante o período de 28 dias. Foi observado diferença estatisticamente significante quando comparamos o grupo em que houve apenas a inoculação de LPS com o grupo em que além da inoculação de LPS foi administrado Celecoxibe, mostrando um aumento do percentual de células mononucleadas neste último grupo $(p<0,05)$. Também foi observado um aumento estatisticamente significante no percentual de células mononucleadas quando comparamos 0 grupo em que foi inoculado o LPS e administrado Indometacina, com o grupo em que apenas o LPS foi inoculado $(p<0,05)$. Não houve diferença estatisticamente significante em relação ao percentual de células mononucleadas entre o grupo de dentes hígidos em relação 
ao grupo em que apenas o LPS foi inoculado $(p>0,05)$. Assim como também não foi observado diferença entre os grupos que houve inoculação de LPS e administração de Celecoxibe e inoculação de LPS e administração de Indometacina $(p>0,05)$.

Ainda em relação ao período de 28 dias, podemos observar na figura 14 a comparação no percentual de células polimorfonucleadas entre os grupos citados anteriormente. Quando comparamos o grupo de dentes hígidos com o grupo em que houve apenas inoculação de LPS, observamos um aumento no percentual de células polimorfonucleadas neste último grupo $(p<0,05)$. Entre o grupo em que houve apenas a inoculação de LPS com o grupo em que além da inoculação de LPS foi administrado Celecoxibe, também foi observada uma diferença estatisticamente significante, mostrando uma diminuição do percentual de células polimorfonucleadas neste último grupo $(p<0,05)$. Também foi observado uma diminuição estatisticamente significante no percentual de células polimorfonucleadas no grupo em que foi inoculado o LPS e administrado Indometacina, quando comparado ao grupo em que foi apenas inoculado o LPS $(p<0,05)$. Entre os grupos com a inoculação LPS e administração de Celecoxibe e inoculação de LPS com administração de Indometacina, não houve uma diferença estatisticamente significante em relação ao percentual de células polimorfonucleadas $(p>0,05)$.

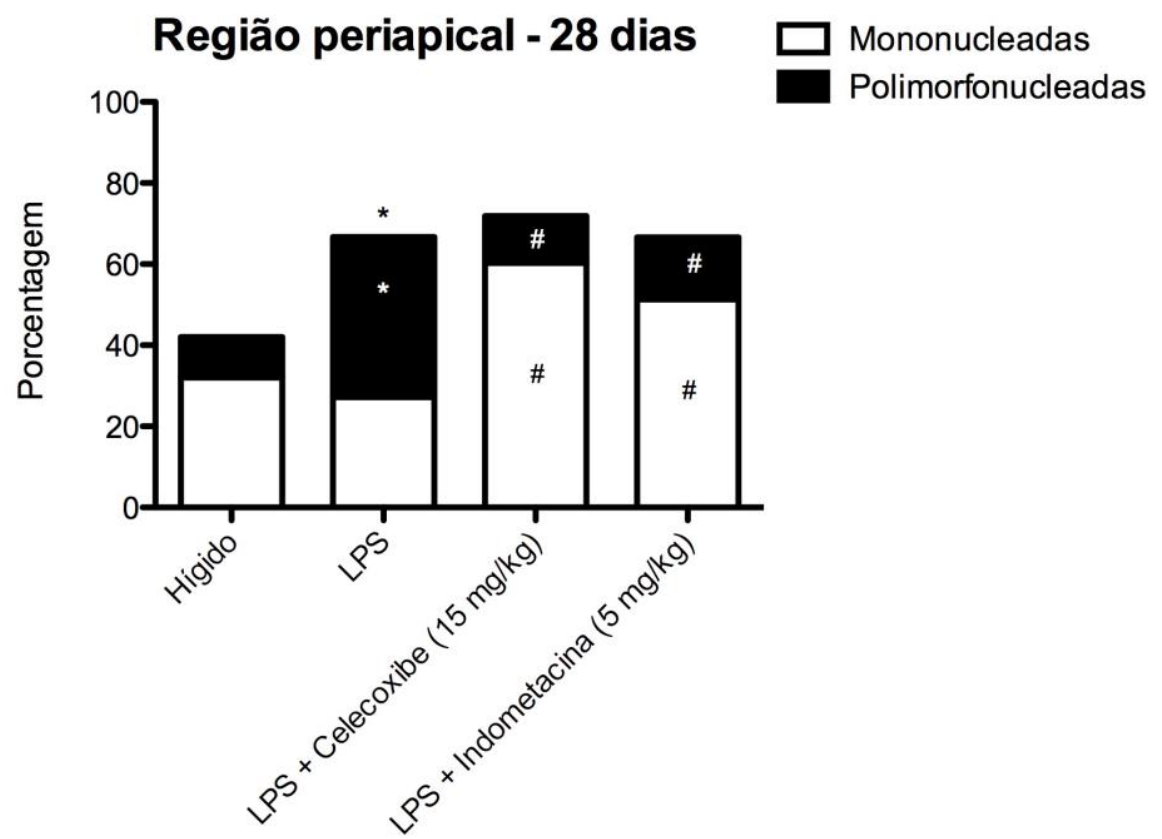

Figura 14. Representação gráfica da comparação dos resultados obtidos após contagem do número de células inflamatórias no período experimental de 28 dias, na região do tecido periapical, nos grupos: dentes hígidos, dentes com inoculação de LPS, dentes com inoculação de LPS e administração de Celecoxibe e dentes com inoculação de LPS e administração de Indometacina. $* p<0,05$ comparado ao grupo de dentes hígidos; ${ }^{\#} p<0,05$ comparado ao grupo com inoculação de LPS; ${ }^{\&} p<0,05$ comparado os grupos LPS + Indometacina em relação ao grupo LPS + Celecoxibe. 
As fotomicrografias representativas dos quadros histológicos do tecido pulpar e da região periapical em dentes hígidos e após 7, 14, 21 e 28 dias da inoculação de LPS e tratamento com Indometacina e Celecoxibe são apresentados nas figuras 15 a 21. 

Figura 15. Fotomicrografias obtidas a partir de dentes hígidos (A, B e C). Área periapical sadia caracterizada pela ausência de células inflamatórias e presença de ligamento periodontal em condições de normalidade. Presença de fibroblastos, cementoblastos e fibras de Sharpey inseridas no cemento. Aumento 20x (A, B) e 40x (C). 
Hígido

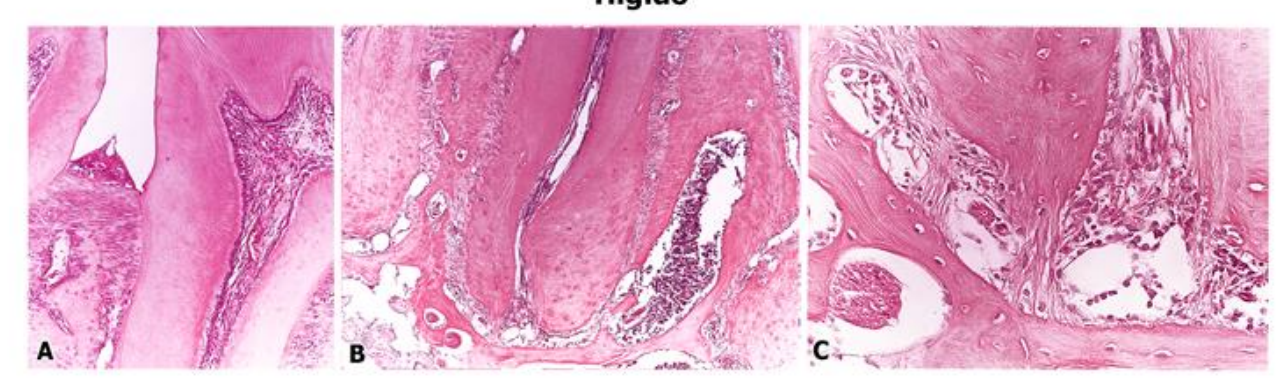




Figura 16. Fotomicrografias obtidas nos períodos experimentais de 7 (A, B e C) e 14 (D, E e F) dias após inoculação de LPS. Presença de polpa necrosada, com moderado infiltrado inflamatório. Presença de um infiltrado inflamatório na região periapical sem reabsorção de tecido ósseo. Aumento 10x (A e D ), 20x (C e E) e 40x (B e F). 


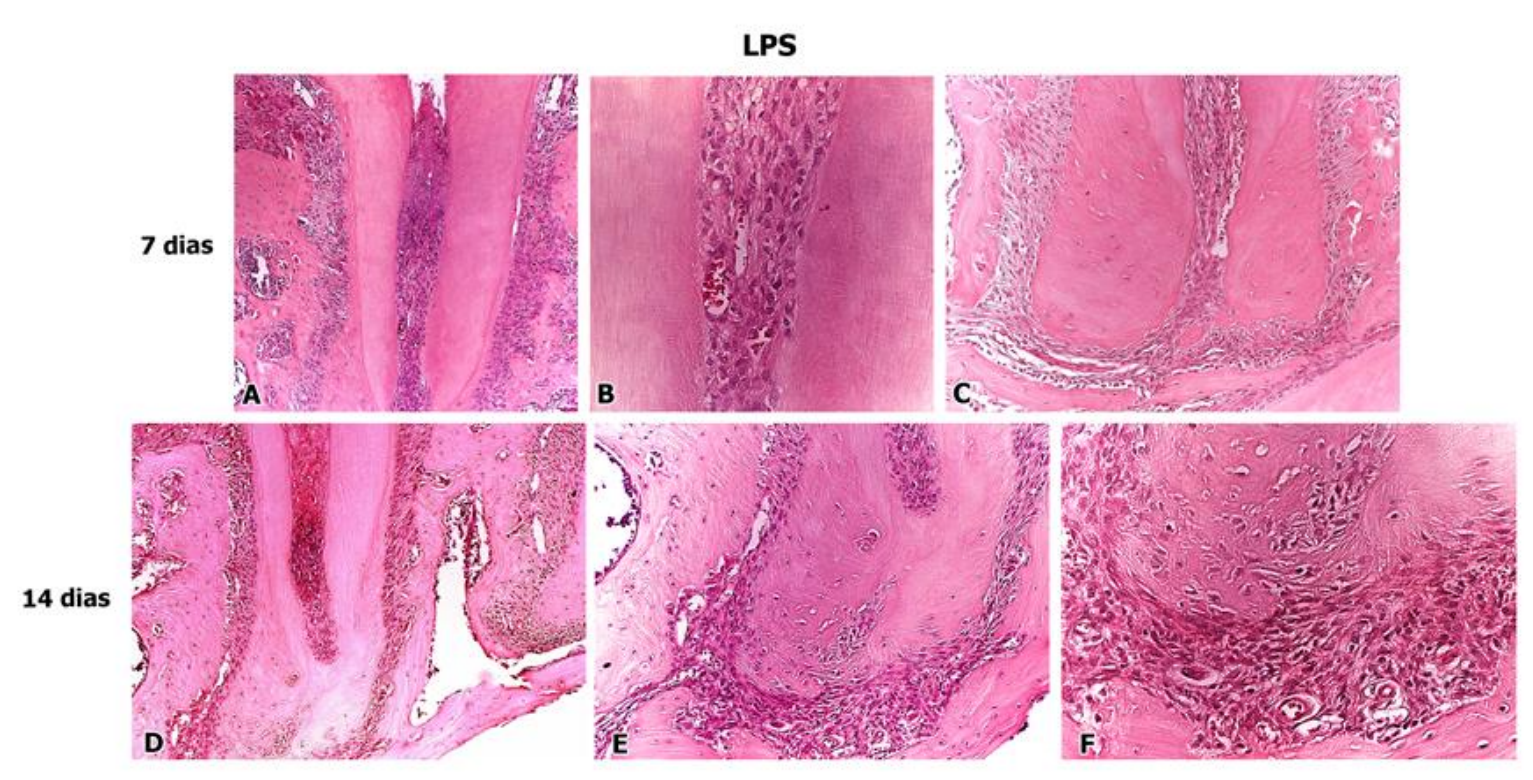




Figura 17. Fotomicrografias obtidas nos diferentes períodos experimentais de 21 (A, B e C) e 28 (D, E e F) dias após inoculação de LPS. Presença de polpa necrosada em maior extensão. Área periapical com presença de um infiltrado inflamatório aumento da espessura do ligamento periodontal, sem reabsorção de tecido ósseo (B). Maior aumento mostrando a presença de células inflamatórias, mononucleadas e polimorfonucleadas, fibroblastos. Aumento 10x (A e D) 20x (B, E e F) e 40x (C). 
LPS

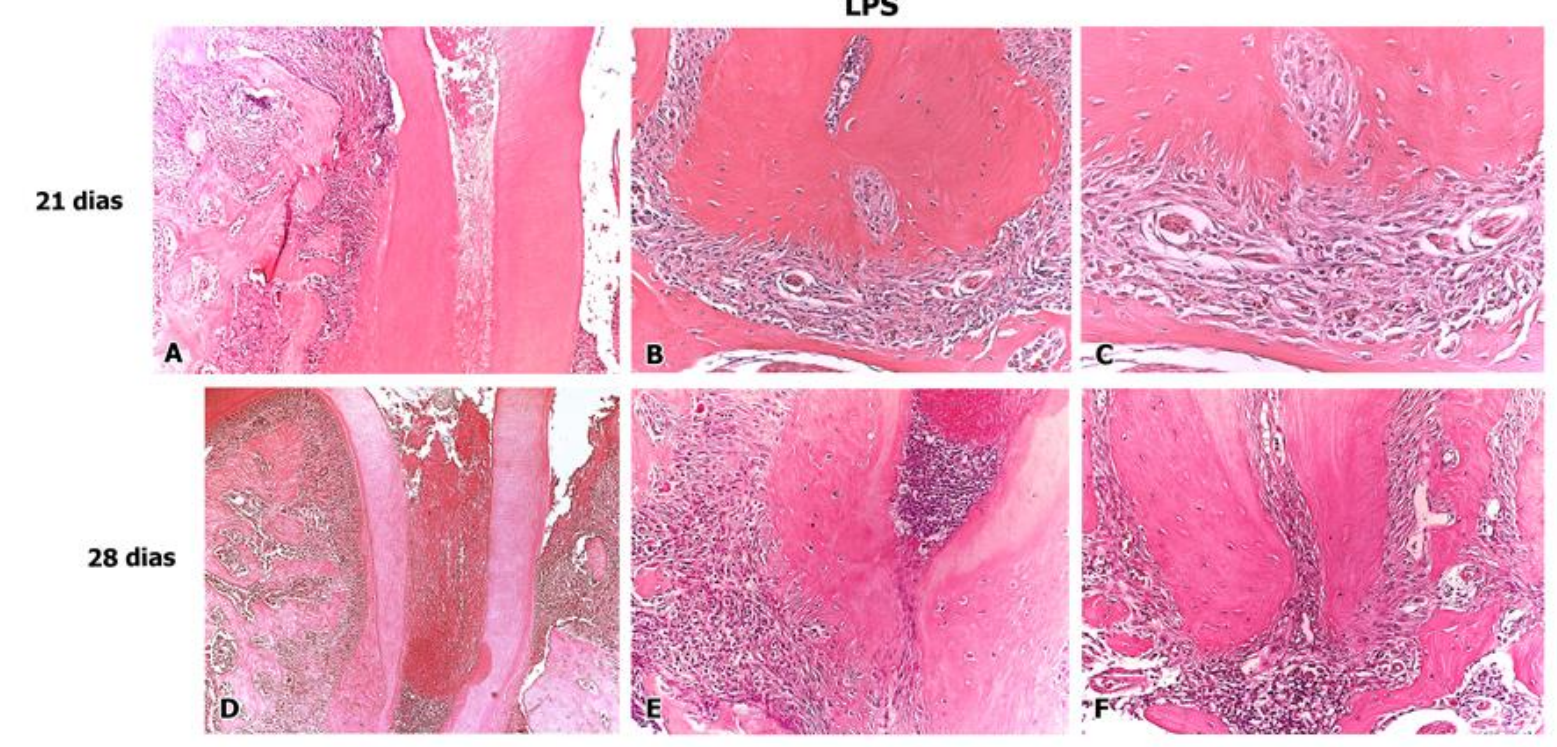




Figura 18. Fotomicrografias obtidas nos períodos experimentais de 7 (A, B e C) e 14 (D, E e F) dias após inoculação de LPS e administração de Celecoxibe. Presença de polpa necrosada no terço cervical, com infiltrado inflamatório. Área periapical com algumas células inflamatórias e fibroblastos em abundância. Aumento 10x (E), 20x (A, B e F) e 40x (C e D). 
Celecoxibe

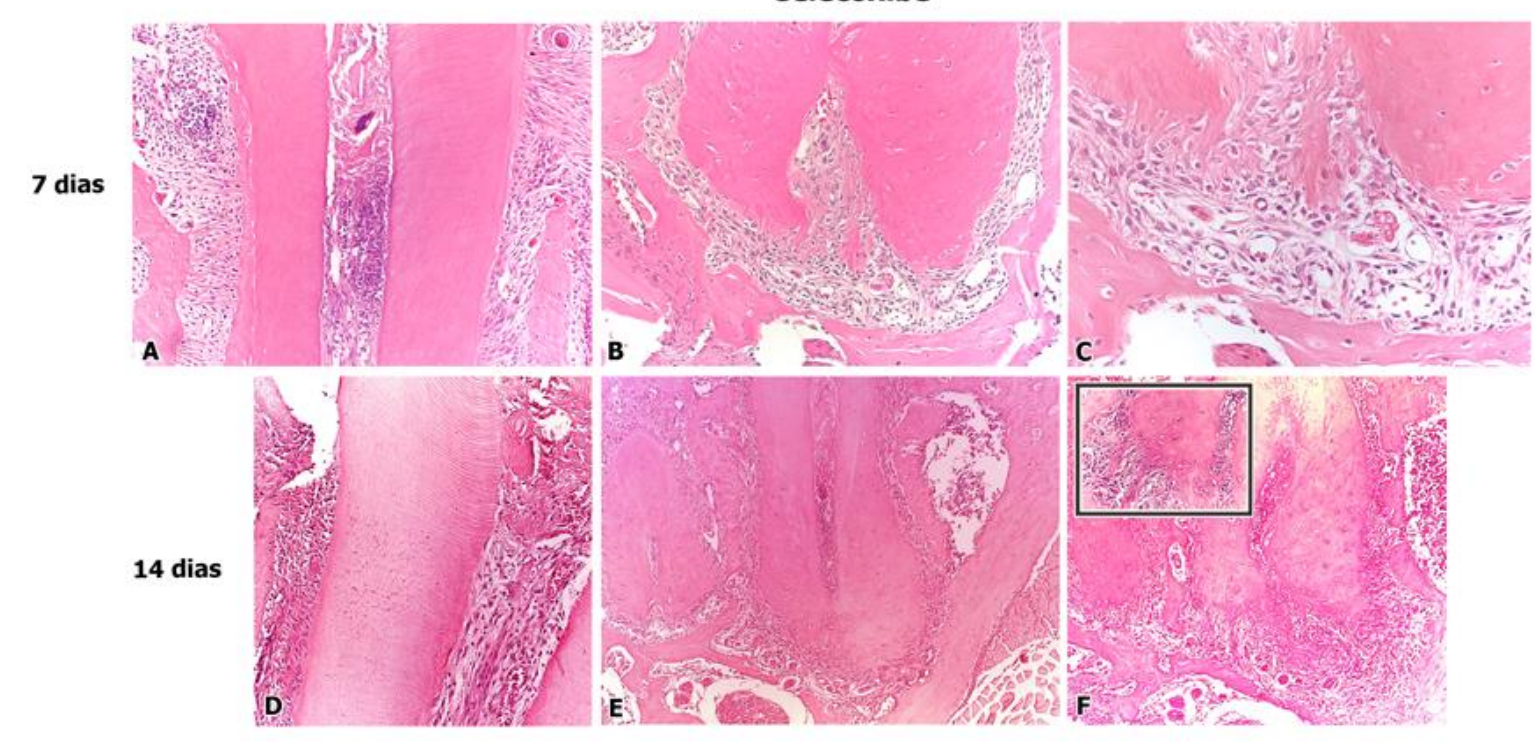




Figura 19. Fotomicrografias obtidas nos períodos experimentais de 21 (A, B e C) e 28 (D, E e F) dias após inoculação de LPS e administração de Celecoxibe. Presença de polpa necrosada e lesão periapical. Área periapical com presença de um infiltrado inflamatório, com predomínio de células mononucleadas. Maior aumento mostrando a presença de células inflamatórias mononucleadas. Aumento 10x (A e D), 20x (B e E) e 40x (C e F). 


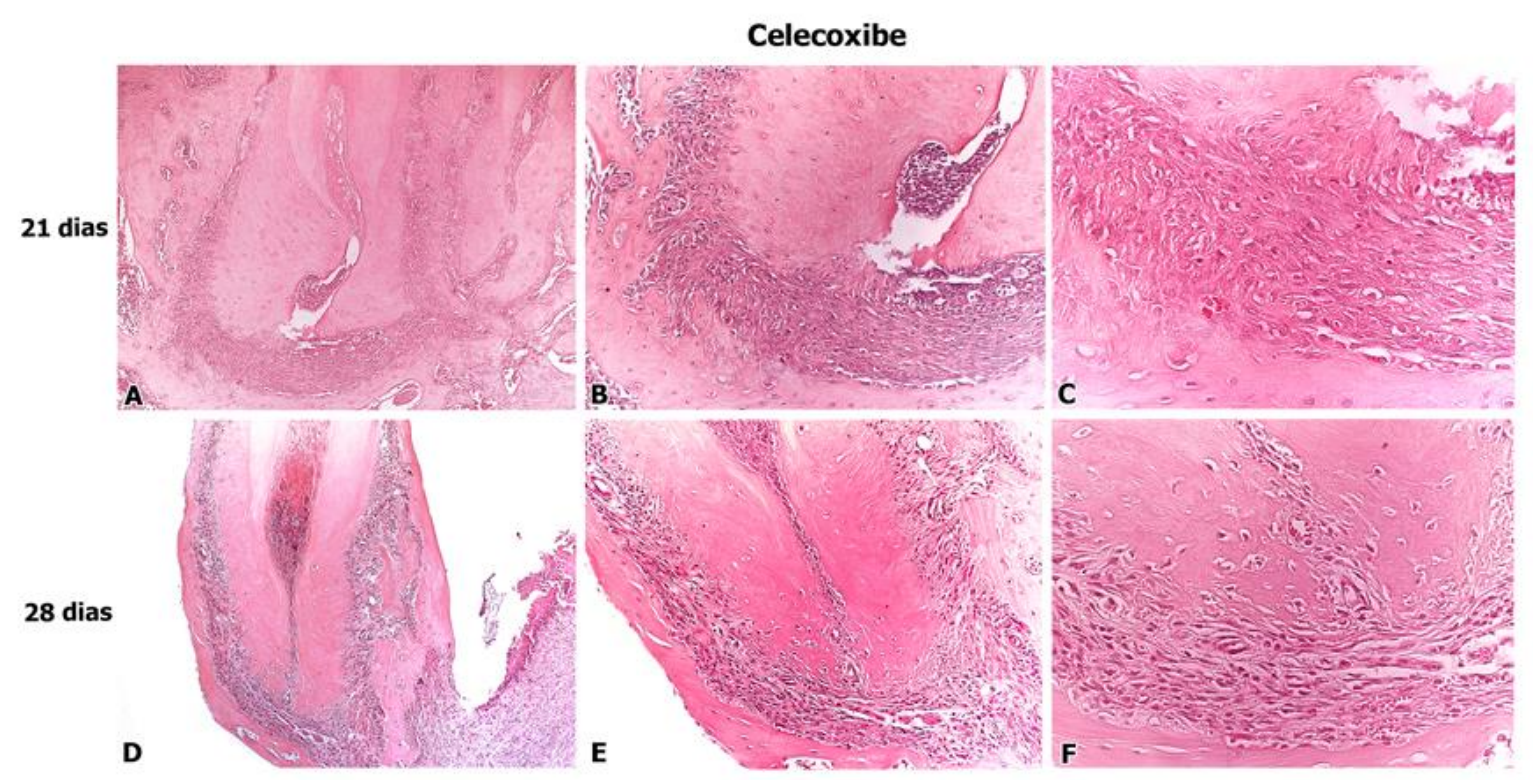




Figura 20. Fotomicrografias obtidas nos períodos experimentais de 7 (A, B e C) e 14 (D, E e F) dias após inoculação de LPS e administração de Indometacina. Presença de polpa necrosada, com infiltrado inflamatório, predominantemente mononuclear. Aumento 10x (A), 20x (B, D e E) e $40 x$ (C e F). 
Indometacina

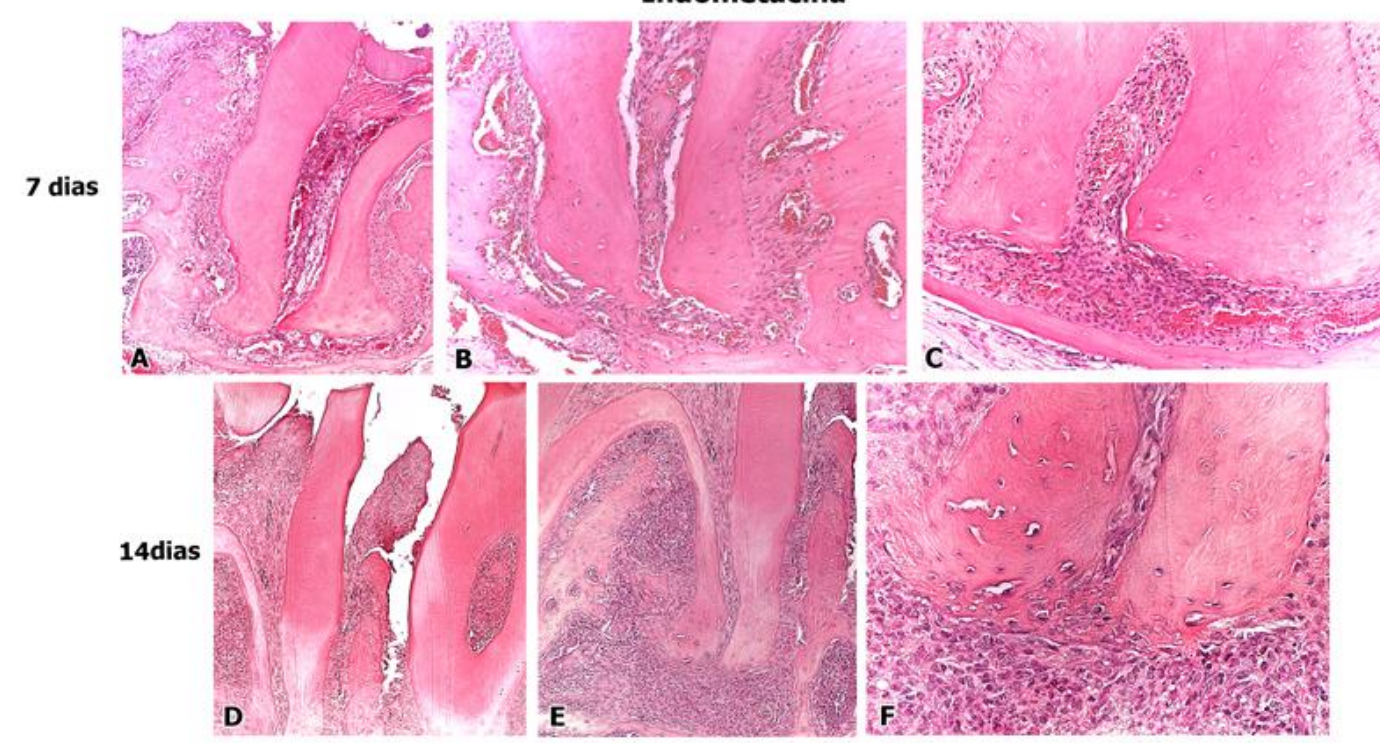




Figura 21. Fotomicrografias obtidas nos períodos experimentais de 21 (A, B e C) e 28 (D, E e F) dias após inoculação de LPS e administração de Indometacina. Presença de polpa necrosada e lesão periapical. Área periapical com presença de um infiltrado inflamatório intenso, com de células mononucleadas e grande quantidade de polimorfonucleadas. Maior aumento mostrando a presença de células inflamatórias. Aumento 10x (D), 20x (A e E) e 40x (B, C e F). 
Indometacina

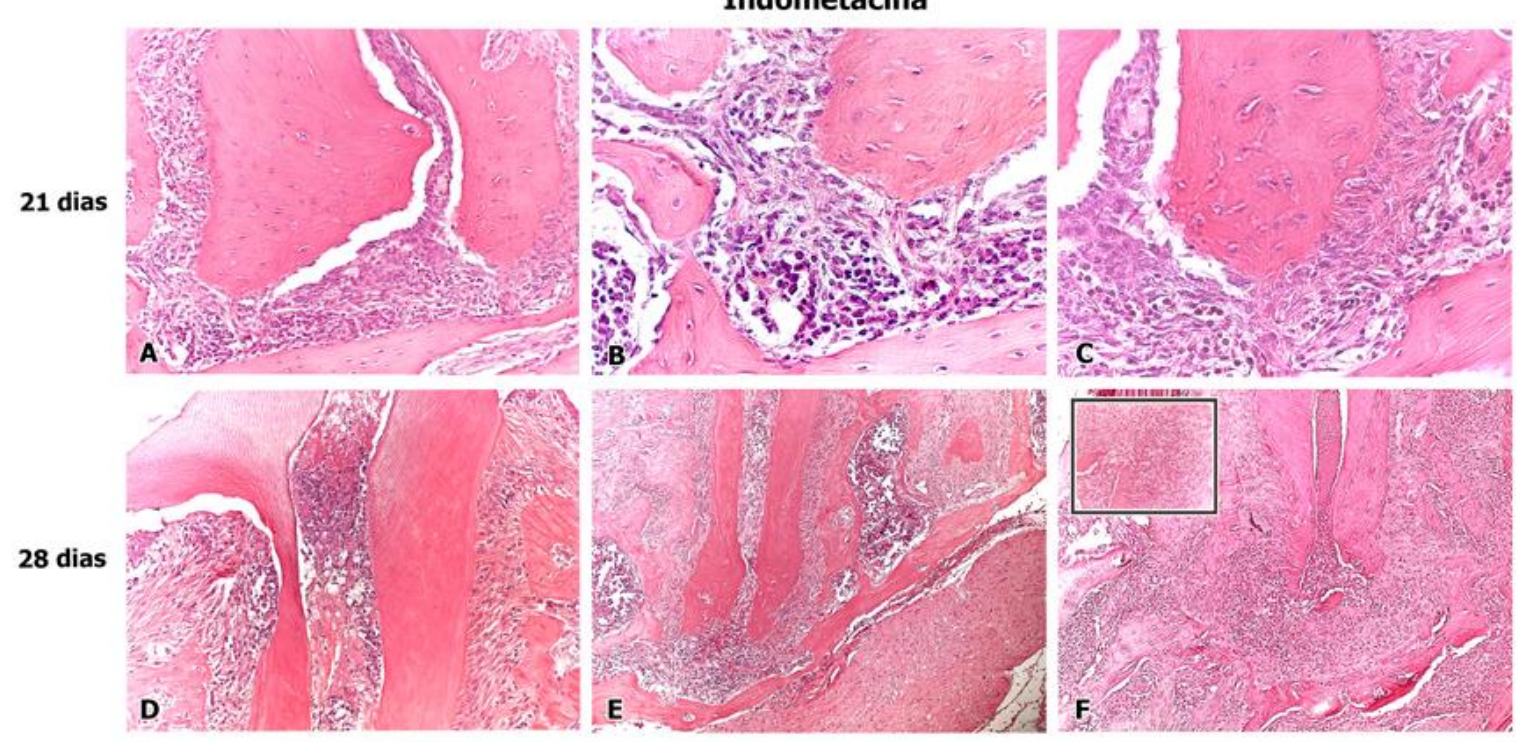





\section{Quantificação de células inflamatórias, mononucleadas e polimorfonucleadas e fibroblastos positivamente marcadas para a enzima COX-2 no tecido pulpar nos diferentes períodos experimentais}

As figuras 22,23 e 24 representam os dados obtidos nos diferentes períodos experimentais de 7, 14, 21 e 28 dias, com relação ao percentual do número de células mononucleadas, polimorfonucleadas e fibroblastos positivas para COX-2 no tecido pulpar, nos terços cervical, médio e apical. Nos dentes hígidos não foram identificadas células positivas para COX-2 e, assim, as comparações foram realizadas em relação ao período de 7 dias após inoculação de LPS na câmara pulpar.

A figura 22 representa os dados obtidos na região do tecido pulpar, no terço cervical, durante todos os períodos experimentais, onde foi comparado o percentual total de células inflamatórias, mononucleadas e polimorfonucleadas, e fibroblastos, positivas para COX-2. Durante o período experimental de 14 e 21 dias observou-se um aumento estatisticamente significante no percentual de células marcadas para COX-2 quando comparado ao período experimental de 7 dias $(p<0,05)$. Porém não foi observado uma diferença estatisticamente significante entre o percentual de células marcadas para COX-2 quando comparamos os períodos de 7 e 28 dias $(p>0,05)$.

A figura 22 também ilustra a comparação do percentual de células mononucleadas positivas para COX-2. Durante os períodos experimentais de 14, 21 e 28 dias observou-se um aumento estatisticamente significante no percentual de células mononucleadas marcadas para COX-2 quando comparado ao período experimental de 7 dias $(p<0,05)$.

Ainda em relação ao terço cervical, podemos observar na figura 22 a comparação no percentual de células polimorfonucleadas entre os períodos já descritos. Durante os períodos experimentais de 14, 21 e 28 dias, observou-se uma diminuição estatisticamente significante no percentual de células polimorfonucleadas marcadas para COX-2 quando comparado ao período experimental de 7 dias $(p<0,05)$.

Não foram observados fibroblastos positivos para COX-2 na região cervical do tecido pulpar durante todos os períodos experimentais. 


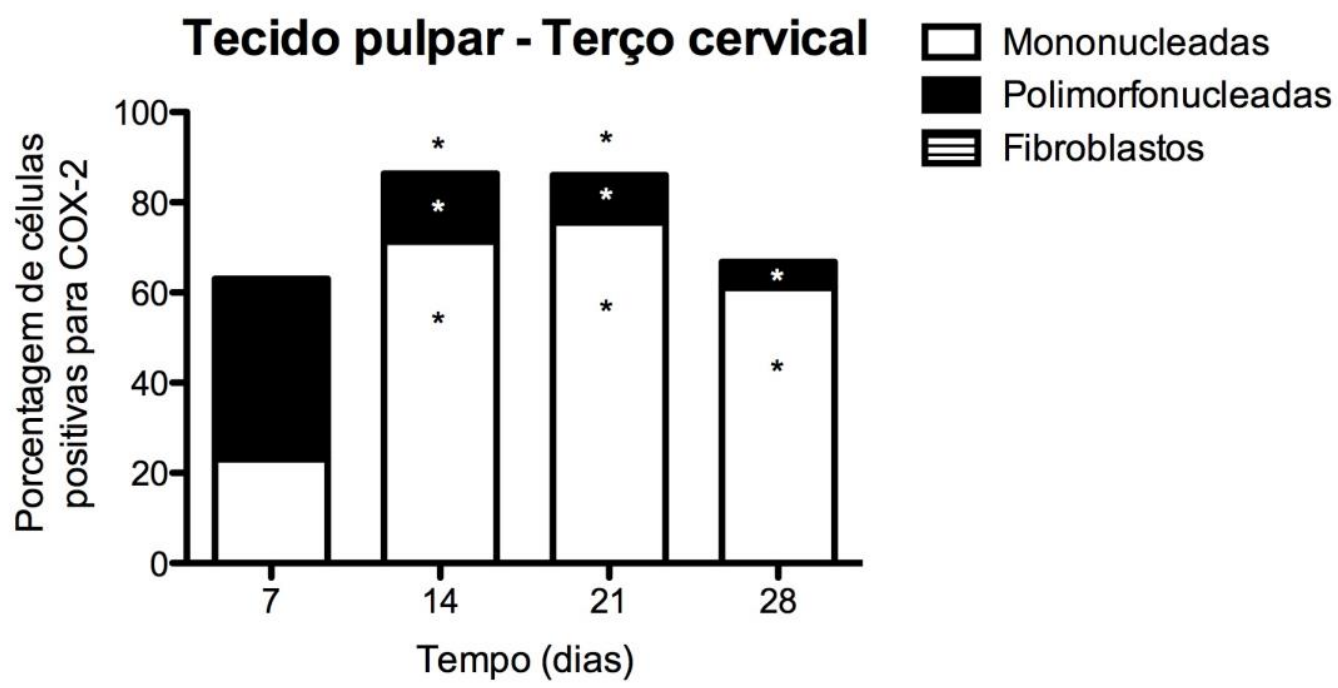

Figura 22. Representação gráfica da comparação dos resultados obtidos após contagem do número de células inflamatórias, mononucleadas e polimorfonucleadas, e fibroblastos, positivas para COX-2, no período experimental de 7, 14, 21 e 28 dias, no terço cervical do tecido pulpar. * $p<0,05$ comparado ao período experimental de 7 dias.

A figura 23 representa os dados obtidos na região do tecido pulpar, no terço médio, durante todos os períodos experimentais, onde foi comparado o percentual total de células inflamatórias, mononucleadas e polimorfonucleadas, e fibroblastos, positivas para COX-2. Durante os períodos experimentais de 14, 21 e 28 dias observou-se um aumento estatisticamente significante no percentual de células marcadas para COX-2 quando comparado ao período experimental de 7 dias $(p<0,05)$.

A figura 23 também ilustra a comparação do percentual de células mononucleadas positivas para COX-2. Durante os períodos experimentais de 14, 21 e 28 dias observou-se um aumento estatisticamente significante no percentual de células mononucleadas marcadas para COX-2 quando comparado ao período experimental de 7 dias $(p<0,05)$.

Ainda em relação ao terço médio, podemos observar na figura 23 a comparação no percentual de células polimorfonucleadas entre os períodos já descritos. Durante os períodos experimentais de 14 e 21 dias, observou-se um aumento estatisticamente significante no percentual de células polimorfonucleadas marcadas para COX-2 quando comparado ao período experimental de 7 dias $(p<0,05)$. Não foi observado uma diferença estatisticamente significante entre o percentual de células polimorfonucleadas marcadas para COX-2 quando comparamos os períodos de 7 e 28 dias $(p>0,05)$.

Não foram observados fibroblastos positivos para COX-2 na região do terço médio, do tecido pulpar, durante todos os períodos experimentais. 


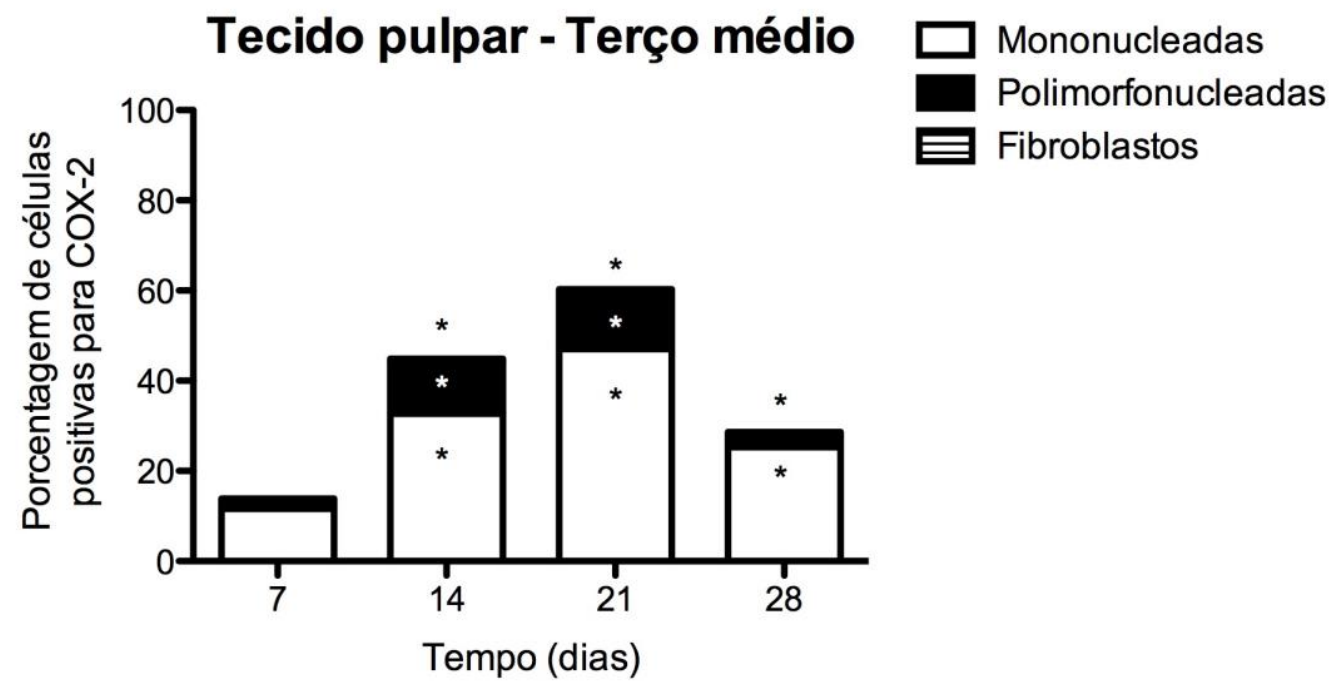

Figura 23. Representação gráfica da comparação dos resultados obtidos após contagem do número de células inflamatórias, mononucleadas e polimorfonucleadas, e fibroblastos, positivas para COX-2, no período experimental de 7, 14, 21 e 28 dias, no terço médio do tecido pulpar. * $p<0,05$ comparado ao período experimental de 7 dias.

A figura 24, representa os dados obtidos na região do tecido pulpar, no terço apical, durante todos os períodos experimentais, onde foi comparado o percentual total de células inflamatórias, mononucleadas e polimorfonucleadas, e fibroblastos, positivas para COX-2. Durante o período experimental de 21 dias observou-se um aumento estatisticamente significante no percentual de células marcadas para COX-2 quando comparado ao período experimental de 7 dias $(p<0,05)$. Não foi observado uma diferença estatisticamente significante entre o percentual de células marcadas para COX-2 quando comparamos os períodos 7 e 14 dias e entre os períodos 7 e 28 dias $(p>0,05)$.

A figura 24 também ilustra a comparação do percentual de células mononucleadas positivas para COX-2. Não foi observado diferença estatisticamente significante entre o percentual de células mononucleadas marcadas para COX-2 quando comparamos todos períodos experimentais com o período de 7 dias $(p>0,05)$.

Ainda em relação ao terço apical, podemos observar na figura 24 a comparação no percentual de células polimorfonucleadas entre os períodos já descritos. Durante o período experimental de 21 dias, observou-se um aumento estatisticamente significante no percentual de células polimorfonucleadas marcadas para COX-2 quando comparado ao período experimental de 7 dias $(p<0,05)$. Não foi observado uma diferença estatisticamente significante entre o percentual de células polimorfonucleadas marcadas para COX-2 quando comparamos os períodos experimentais de 14 dias e 28 dias com o tempo de 7 dias $(p>0,05)$. 
Por fim, foi observado um aumento estatisticamente significante de fibroblastos positivos para COX-2 na região apical do tecido pulpar, durante o período experimental de 21 dias e 28 dias quando comparado ao período de 7 dias $(p<0,05)$.

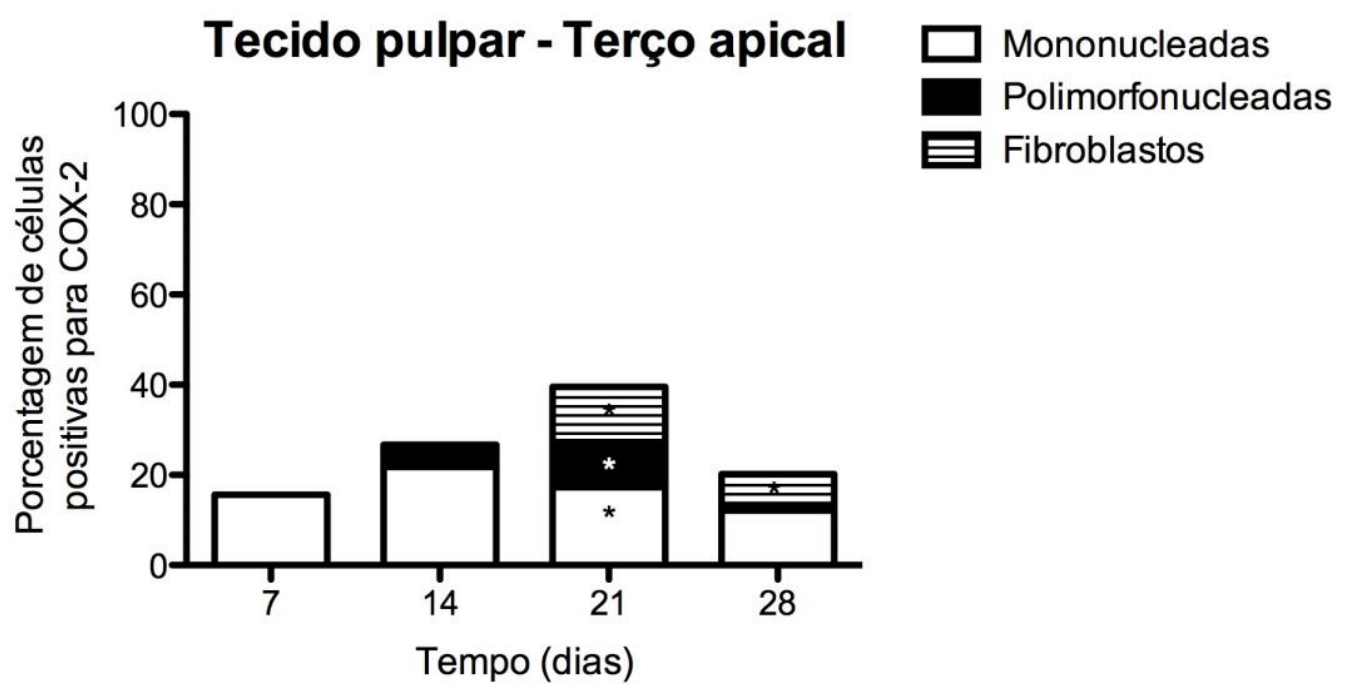

Figura 24. Representação gráfica da comparação dos resultados obtidos após contagem do número de células inflamatórias, mononucleares e polimorfonucleares, e fibroblastos, positivas para COX-2, no período experimental de 7, 14, 21 e 28 dias, no terço apical do tecido pulpar. * $p<0,05$ comparado ao período experimental de 7 dias.

Quantificação de células inflamatórias, mononucleadas e polimorfonucleadas, e fibroblastos positivamente marcadas para a enzima COX-2 na região periapical nos diferentes períodos experimentais

A figura 25 representa os dados obtidos nos diferentes períodos experimentais de $7,14,21$ e 28 dias, com relação ao percentual de células mononucleadas, polimorfonucleadas e fibroblastos positivos para COX-2 na região do tecido periapical, após a inoculação de LPS.

Através dos dados obtidos na região do tecido periapical durante todos os períodos experimentais, foi comparado o percentual total de células inflamatórias, mononucleadas e polimorfonucleadas, e fibroblastos, positivas para COX-2. Durante o período experimental de 21 dias observou-se um aumento estatisticamente significante no percentual de células marcadas para COX-2 quando comparado ao período experimental de 7 dias $(p<0,05)$. Não foi observado uma diferença estatisticamente significante entre 0 percentual de células marcadas para COX-2 quando comparamos os períodos de 14 e 28 dias com o tempo de 7 dias $(p>0,05)$. 
A figura 25 também ilustra a comparação do percentual de células mononucleadas positivas para COX-2. Não foi observado uma diferença estatisticamente significante entre o percentual de células mononucleadas marcadas para COX-2 quando comparamos todos os períodos com o tempo de 7 dias.

Ainda em relação a região periapical, podemos observar na figura 25 a comparação no percentual de células polimorfonucleadas positivas para COX-2 entre os períodos já descritos. Não foi observado diferença estatisticamente significante entre o percentual de células polimorfonucleadas marcadas para COX-2 quando comparamos todos os períodos com o tempo de 7 dias $(p>0,05)$.

Por fim, foi observado um aumento estatisticamente significante de fibroblastos positivos marcados para COX-2 na região periapical, durante o período experimental de 21 dias quando comparado ao período de 7 dias $(p<0,05)$. Não foi observado uma diferença estatisticamente significante entre o percentual de fibroblastos marcadas para COX-2 quando comparamos os períodos de 14 e 28 dias com o tempo de 7 $\operatorname{dias}(p>0,05)$.

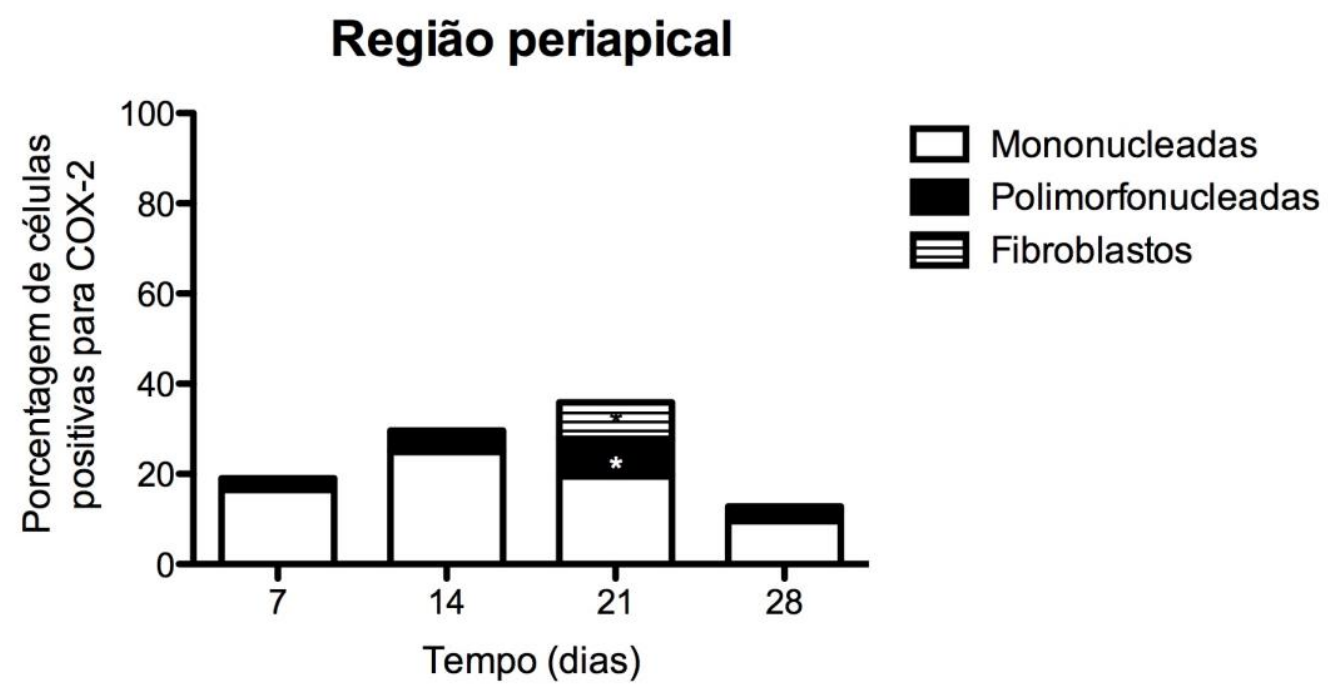

Figura 25. Representação gráfica da comparação dos resultados obtidos após contagem do número de células inflamatórias, mononucleadas e polimorfonucleadas, e fibroblastos, positivos para COX-2, no período experimental de 7, 14, 21 e 28 dias, na região periapical. $* p<0,05$ comparado ao período experimental de 7 dias.

As fotomicrografias representativas das marcações imunohistoquímicas para COX-2 no tecido pulpar e na região periapical em dentes hígidos e após 7, 14, 21 e 28 dias da inoculação de LPS são apresentados nas figuras 26 a 28. 


Figura 26. Fotomicrografias obtidas a partir de dentes hígidos após realização da técnica de imunohistoquímica para marcação de COX-2 (A, B e C). Aumento 20x (A) e 40x (C). 
Hígido - Ciclo-oxigenase - 2 (COX - 2)

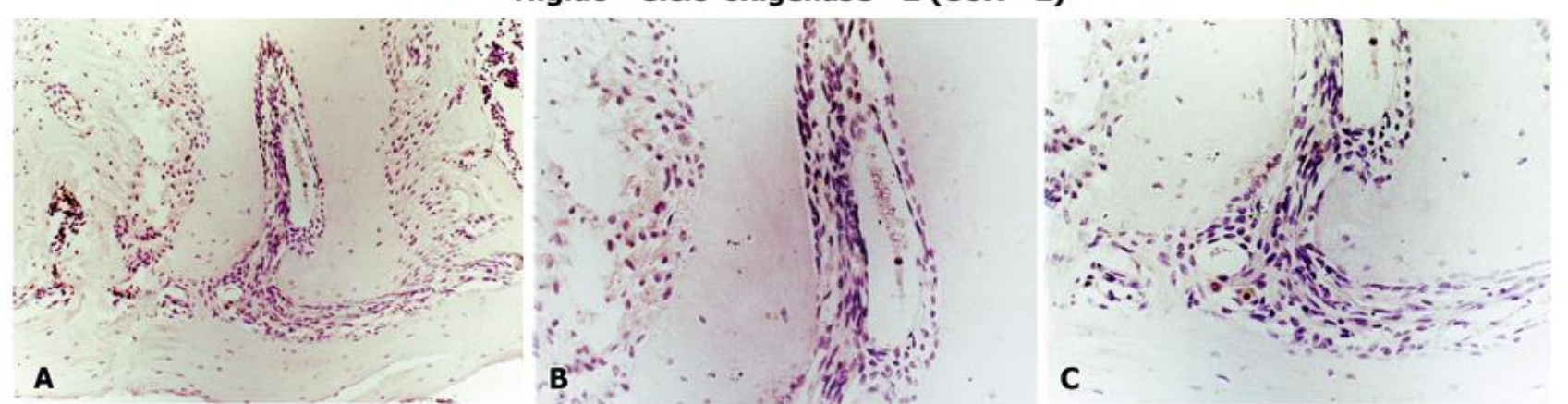




Figura 27. Fotomicrografias obtidas a partir de dentes com inoculação de LPS após realização da técnica de Imunohistoquímica para marcação de COX-2 nos períodos experimentais de 7 (A, B e C) e 14 (D, E e F) dias. A figura (C) representa o controle da imunohistoquímica no qual foi omitido o anticorpo primário. Aumento 20x (A, C e F) e 40x (B, D e E). 
LPS - Ciclo-oxigenase - 2 (COX - 2)

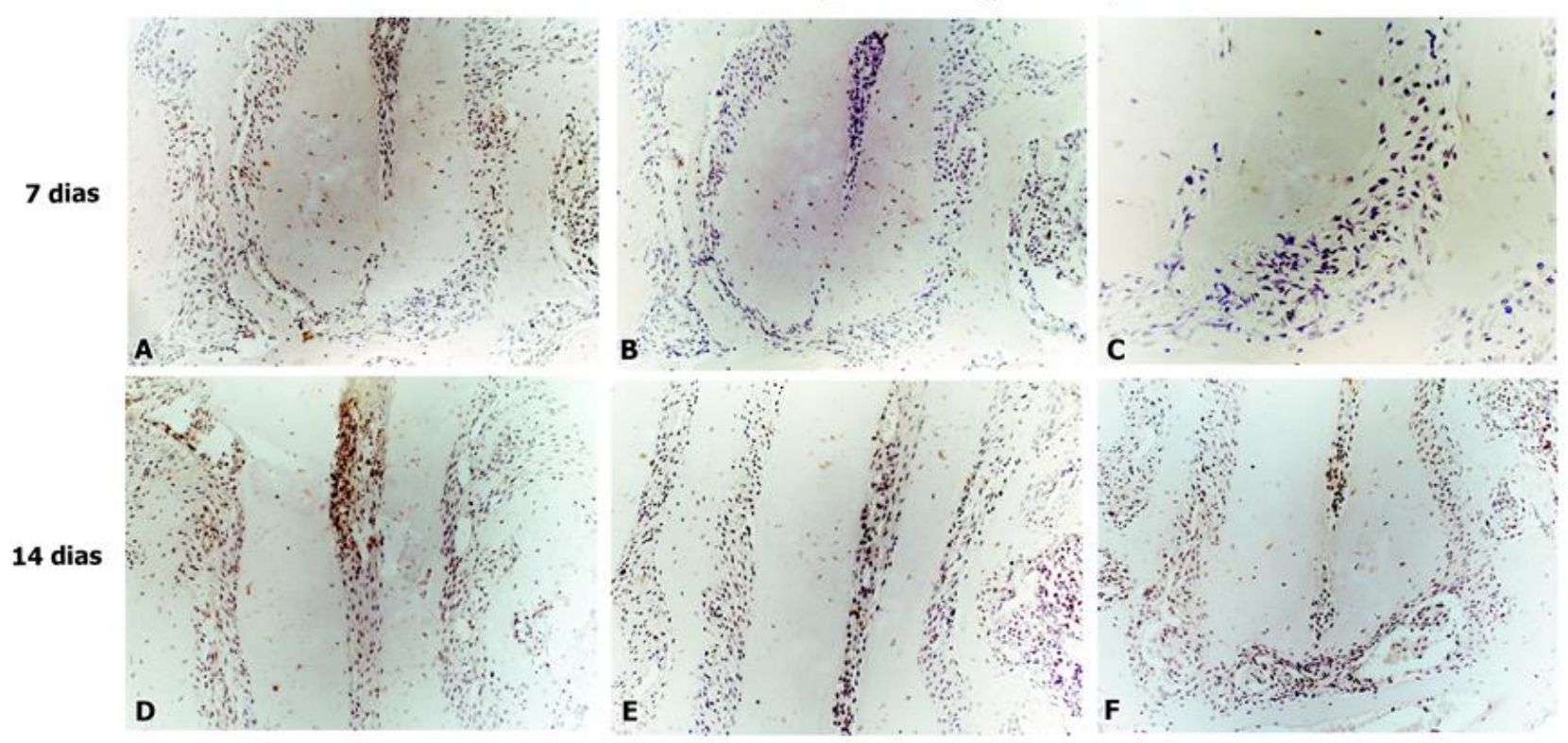




Figura 28. Fotomicrografias obtidas a partir de dentes com inoculação de LPS após realização da técnica de Imunohistoquímica para marcação de COX-2 nos períodos experimentais de 21 (A, B e C) e 28 (D, E e F) dias após inoculação de LPS. Aumento 20x (A, B, D e F) e 40x (C e E). 
LPS - Ciclo-oxigenase - 2 (COX - 2)

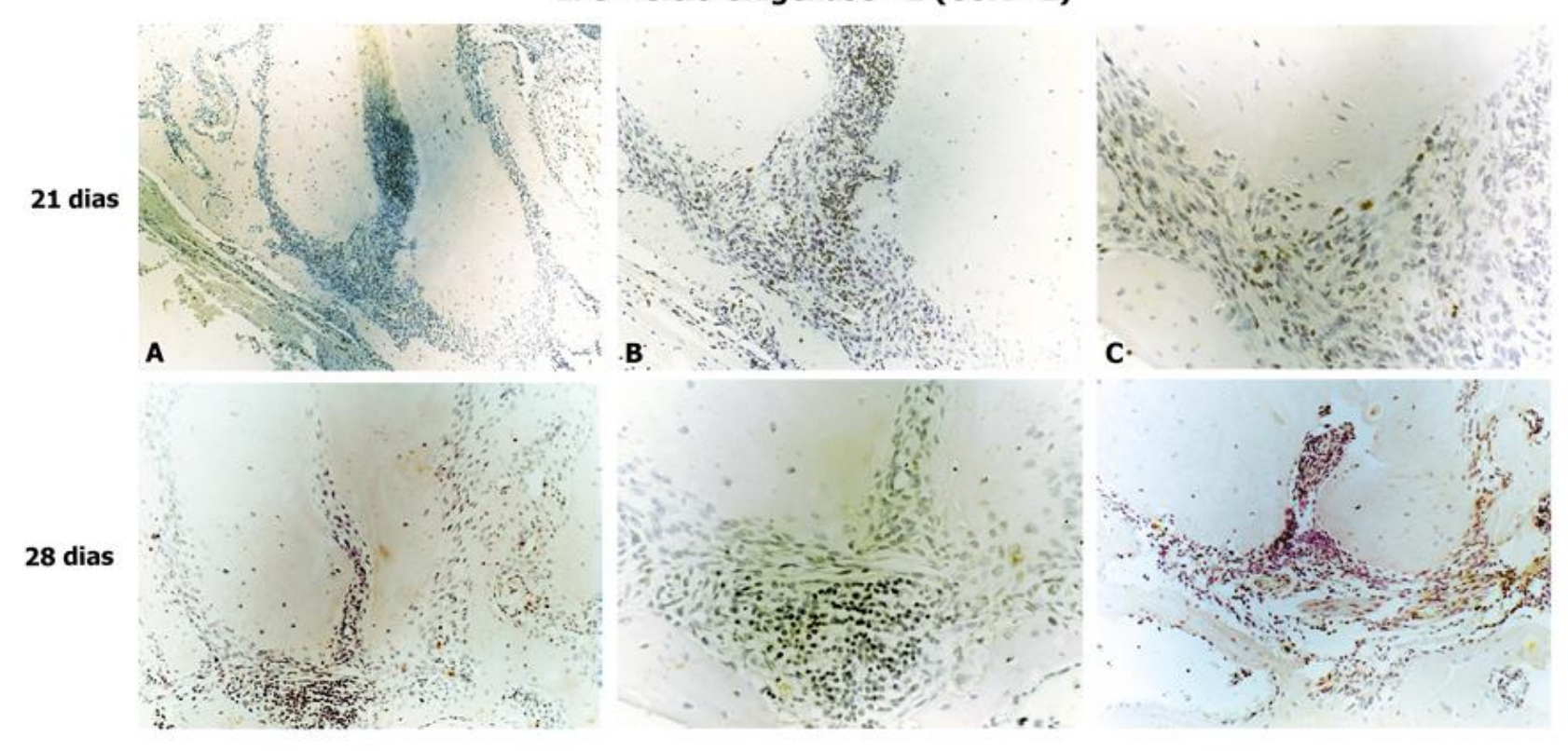





\section{LPS modula in vívo a expressão de genes envolvidos no metabolismo ósseo}

No período de 7 dias após inoculação de LPS nos canais radiculares de molares de camundongos, dos 84 genes avaliados pelo PCR array de genes relacionados ao metabolismo ósseo (Tabela 1), 5 genes não foram detectados, Ahsg, Bmp5, Enam, Fgf3 e Tnf.

Trinta e seis genes foram estimulados em relação ao grupo controle. Destes, o efeito do LPS foi mais notável na expressão do RNAm para Bmp2, Bgn, Runx2, Scarb1 e Vcam1 seguido pelos genes Anxa5, Ambn, Bmp3, Bmpr1b, Col1a1, Col5a1, Col4a2, Comp, Csf2, Csf3, Fgf2, Icam1, Igf1r, Itga2, Itga3, Itgam, Mmp2, Mmp9, Msx1, Pdgfa, Serpinh1, Smad2, Smad3, Sox9, Tfip11, Tgfb1, Tgfb2, Tgfb3, Tgfbr2, Tgfbr3 e Vegfa (Figuras 29 a 34).

No período de 14 dias após inoculação de LPS nos canais radiculares de molares de camundongos, dos 84 genes avaliados pelo PCR array de genes relacionados ao metabolismo ósseo, 2 genes não foram detectados Bmp5 e Fgfr1.

Cinquenta e três genes foram estimulados em relação ao grupo controle. Destes, o efeito do LPS foi mais notável na expressão do RNAm para Ambn, Ahsg, Igf1r, Flt1 e Vcam1, seguido pelos genes Bmp1, Bmp3, Bmpr1b, Cdh11, Col7a1, Csf2, Csf3, Ctsk, Enam, Fgf1, Fgfr2, Itgam, Mmp10, Msx1, Runx2, Smad1, Smad2, Smad3, Sox9, Tfip11, Tgfb2, Tgfb3, Tnf, Vdr, Vegfa, Col6a2, Col6a1, Col4a2, Col2a1, Col1a1,Col1a2, Bmp1, Bmp4, Bmpr1a, Tgfb1, Tgfbr1, Col10a1, Col11a1, Bgn, Dmp1, Mmp9, Phex, Serpinh1, Cd36, Comp, Fn1, Nfkb1 e Smad2 (Figuras 35 a 40).

\section{A administração de Indometacina ou Celecoxibe modularam diferencialmente a expressão de genes envolvidos no metabolismo ósseo após inoculação de LPS na câmara pulpar}

Após a realização do PCR array, foi demonstrado que o tratamento com Indometacina e Celecoxibe, nos períodos de 7 e 14 dias, modularam diferencialmente a expressão de genes envolvidos no metabolismo ósseo, após a inoculação de LPS na câmara pulpar (figuras 29 a 40).

Dentre os genes que apresentaram uma expressão mais elevada após a administração de Indometacina, quando comparados ao grupo LPS, nos períodos de 7 e/ou 14 dias, podemos citar Bmp3, Bmpr1b, Col10a1, Col14a1, Col6a1, Col7a, Ahsg, Bgn, Msx1, Icam1, Itga2, Itga2b, Vcam1,Fgf2, Fgf3, Flt1, Vegfa e Csf3. Por outro lado, os genes Bmp2, Bmp4, Tgfb2, Tgfbr, Col6a1, Alpl, Mmp9, Ahsg, Nfkb1, Runx2, Sox2, Smad1, Vcam1, Cd36, 
Csf2 e Igf1r apresentaram uma expressão reduzida quando comparados ao grupo LPS, nos períodos de 7 e/ou 14 dias.

Dentre os genes mais expressos após a administração de Celecoxibe, quando comparados ao grupo LPS, nos períodos de 7 e/ou 14 dias, estão Bmpr1b, Tgfbr1, Ahsg, Bgn, Msx1, Smad1, Smad2, Icam1, Itga2b, Vcam1, Csf3, Fgf3, Vdr, Fgfr1 e Vegfa. Por outro lado, os genes Bmp2, Bmp4, Tgfb2, Tgfbr1, Tgfbr, Col1a1, Col4a2, Col4a1, Alpl, Mmp9, NfkB1, Runx2, Sox2, Msx1, Itga3, Scarb1, CD36, Vcam, Egf, Vegfa, Csf2, Flt1 e Igf1r apresentaram uma expressão menor quando comparados ao grupo LPS, nos períodos de 7 e/ou 14 dias.

Quando comparamos os grupos em que foi realizada a administração de inibidores seletivo e não seletivo para COX-2, observamos uma maior expressão dos genes Bmp3, Bmp, Col1a1, Col10a1,Col4a1, Col4a2, Col6a1, Col7a1, Col14a1, Ahsg, Bgn, Nfkb1, Runx2, Itga3, Vcam1, Scarb1, Anxa5, Csf3, Egf, Flt1 e Vegfa para o grupo em que a Indometacina foi administrada, nos períodos de 7 e/ou 14 dias. Por outro lado, os genes Bmpr1b, Tgfbr, Col10a1, Ahsg, Sox9, Smad1, Smad2, Itga2, Vcam1, Csf3, Vdr, Csf2, fgf3, Fgfr1 e Vegfa apresentaram maior expressão quando o Celecoxibe foi utilizado nos períodos de 7 e/ou 14 dias.

Fatores de crescimento e diferenciação celular

BMPs e TGF $\beta$

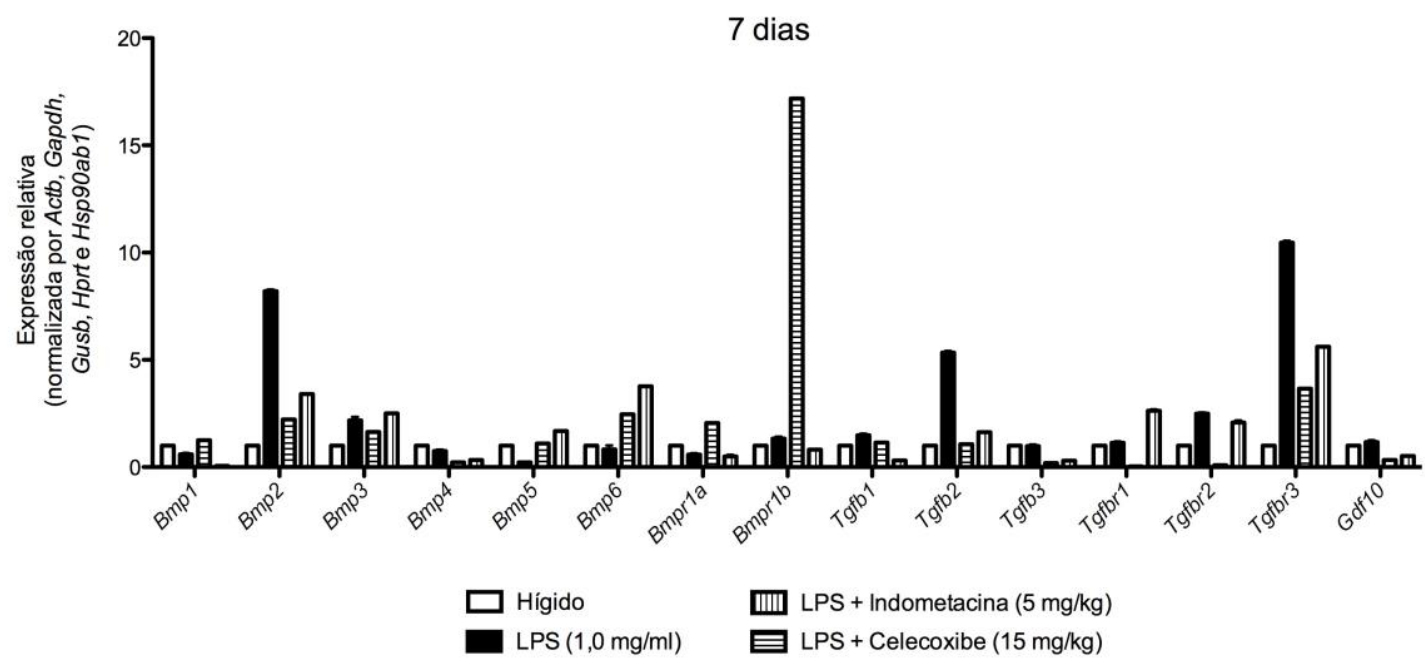

Figura 29. Expressão relativa dos genes que codificam fatores de crescimento e diferenciação celular da superfamília das proteínas ósseas morfogenéticas (BMPs) e do fator de crescimento transformadorbeta (TGF- $\beta$ ) aos 7 dias após inoculação de LPS em dentes de camundongos, com e sem administração diária de Indometacina ou Celecoxibe. 
Fatores de crescimento e diferenciação celular

Outras

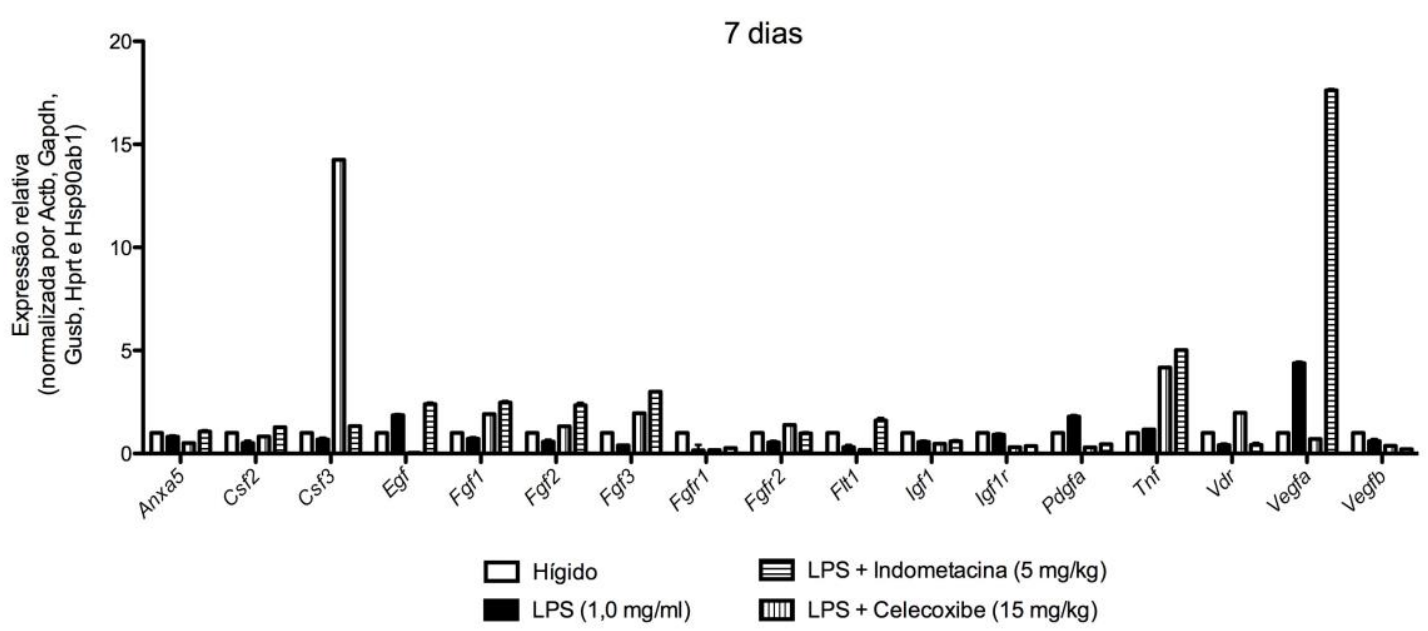

Figura 30. Expressão relativa dos genes que codificam fatores de crescimento e diferenciação celular aos 7 dias após inoculação de LPS em dentes de camundongos, com e sem administração diária de Indometacina ou Celecoxibe.

\section{Proteínas da matriz extracelular}

\section{Colagênicas}

7 dias

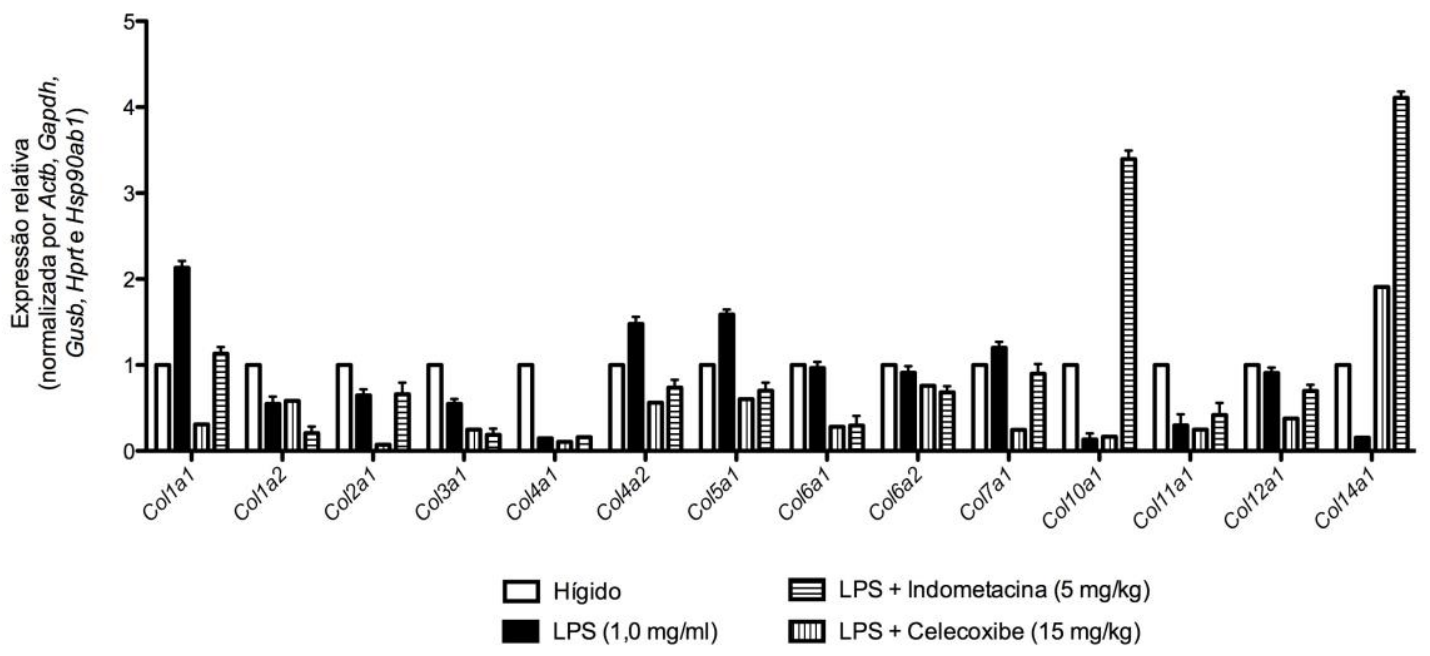

Figura 31. Expressão relativa dos genes que codificam proteínas da matriz extracelular colagênicas aos 7 dias após inoculação de LPS em dentes de camundongos, com e sem administração diária de Indometacina ou Celecoxibe. 


\section{Proteínas da matriz extracelular}

\section{Não colagênicas}

7 dias

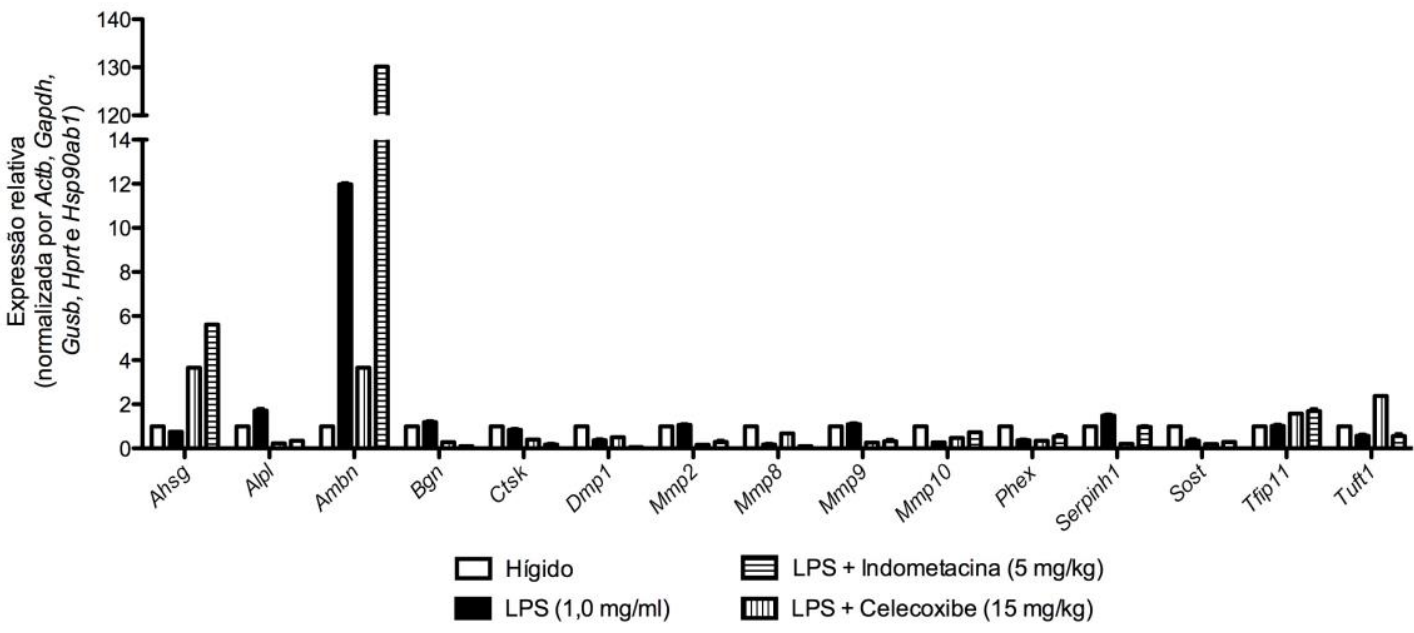

Figura 32. Expressão relativa dos genes que codificam proteínas da matriz extracelular não colagênicas aos 7 dias após inoculação de LPS em dentes de camundongos, com e sem administração diária de Indometacina ou Celecoxibe.

\section{Moléculas de adesão celular}

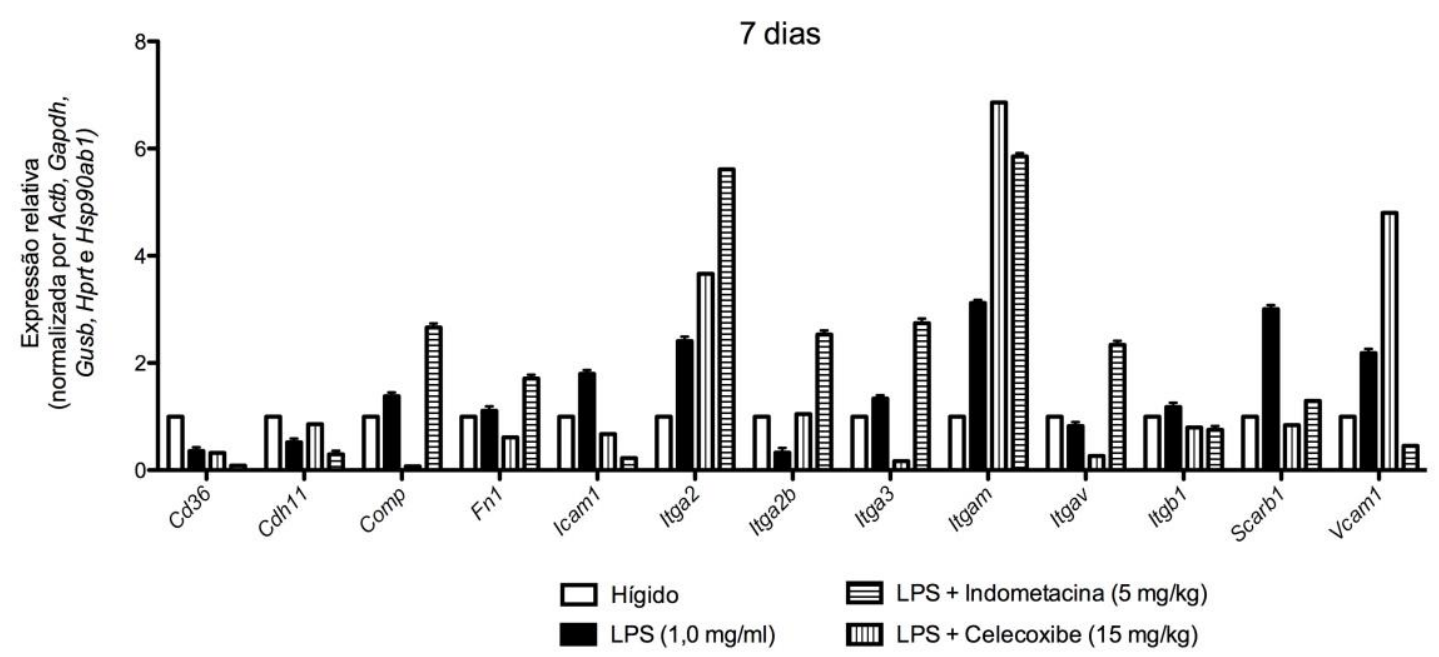

Figura 33. Expressão relativa dos genes que codificam moléculas de adesão celular aos 7 dias após inoculação de LPS em dentes de camundongos, com e sem administração diária de Indometacina ou Celecoxibe. 


\section{Fatores de transcrição}

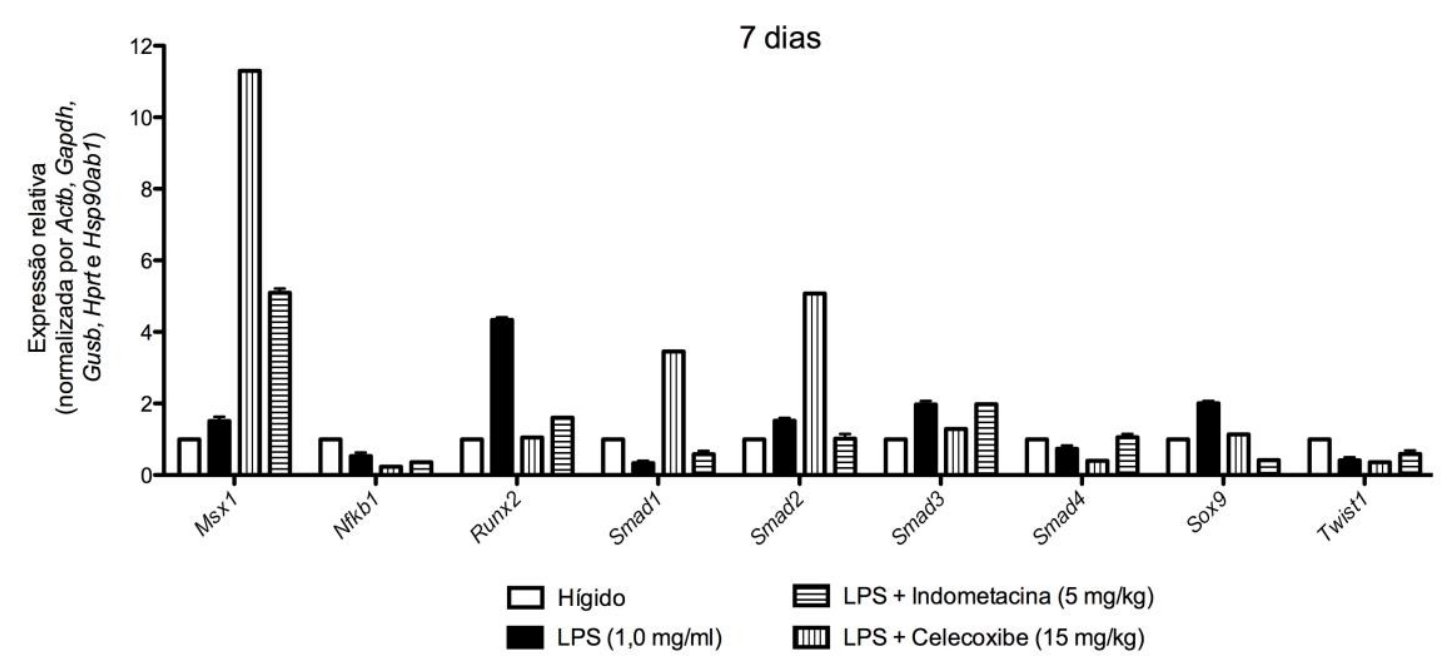

Figura 34. Expressão relativa dos genes que codificam fatores de transcrição aos 7 dias após inoculação de LPS em dentes de camundongos, com e sem administração diária de Indometacina ou Celecoxibe.

Fatores de crescimento e diferenciação celular

BMPs e TGF $\beta$

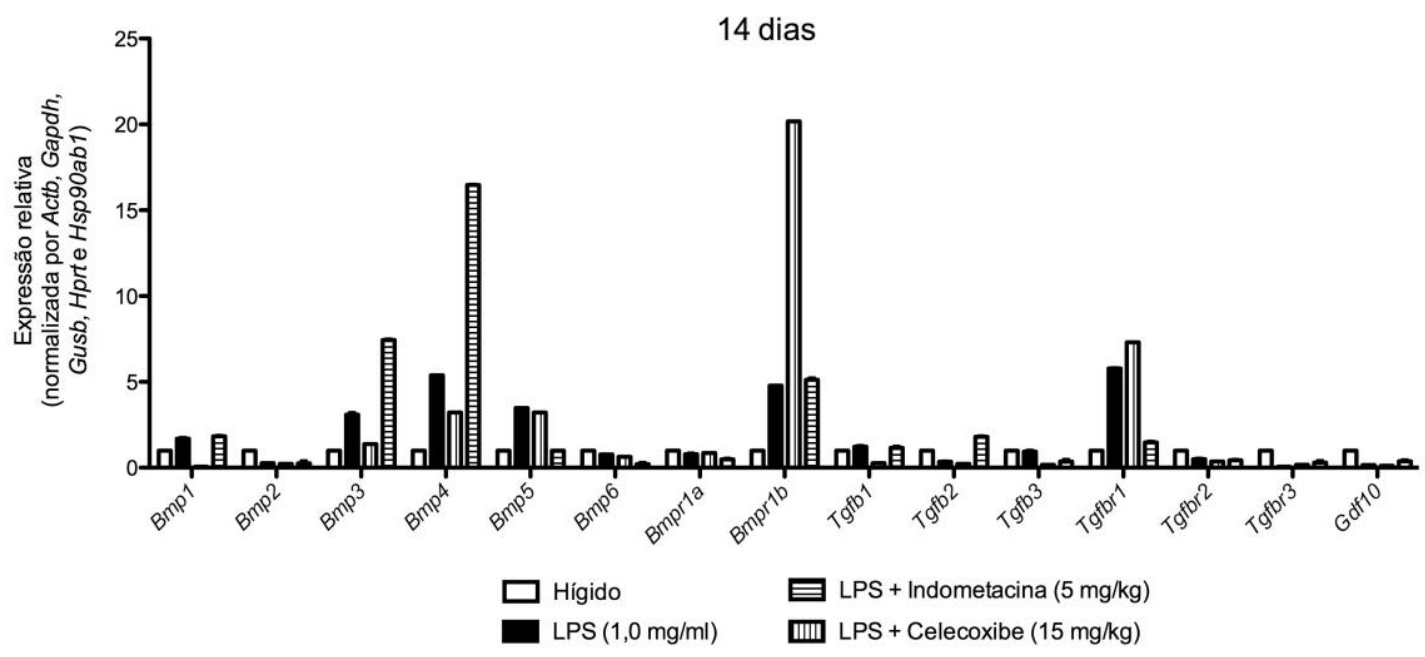

Figura 35. Expressão relativa dos genes que codificam fatores de crescimento e diferenciação celular da superfamília das proteínas ósseas morfogenéticas (BMPs) e do fator de crescimento transformadorbeta (TGF- $\beta$ ) aos 14 dias após inoculação de LPS em dentes de camundongos, com e sem administração diária de Indometacina ou Celecoxibe. 


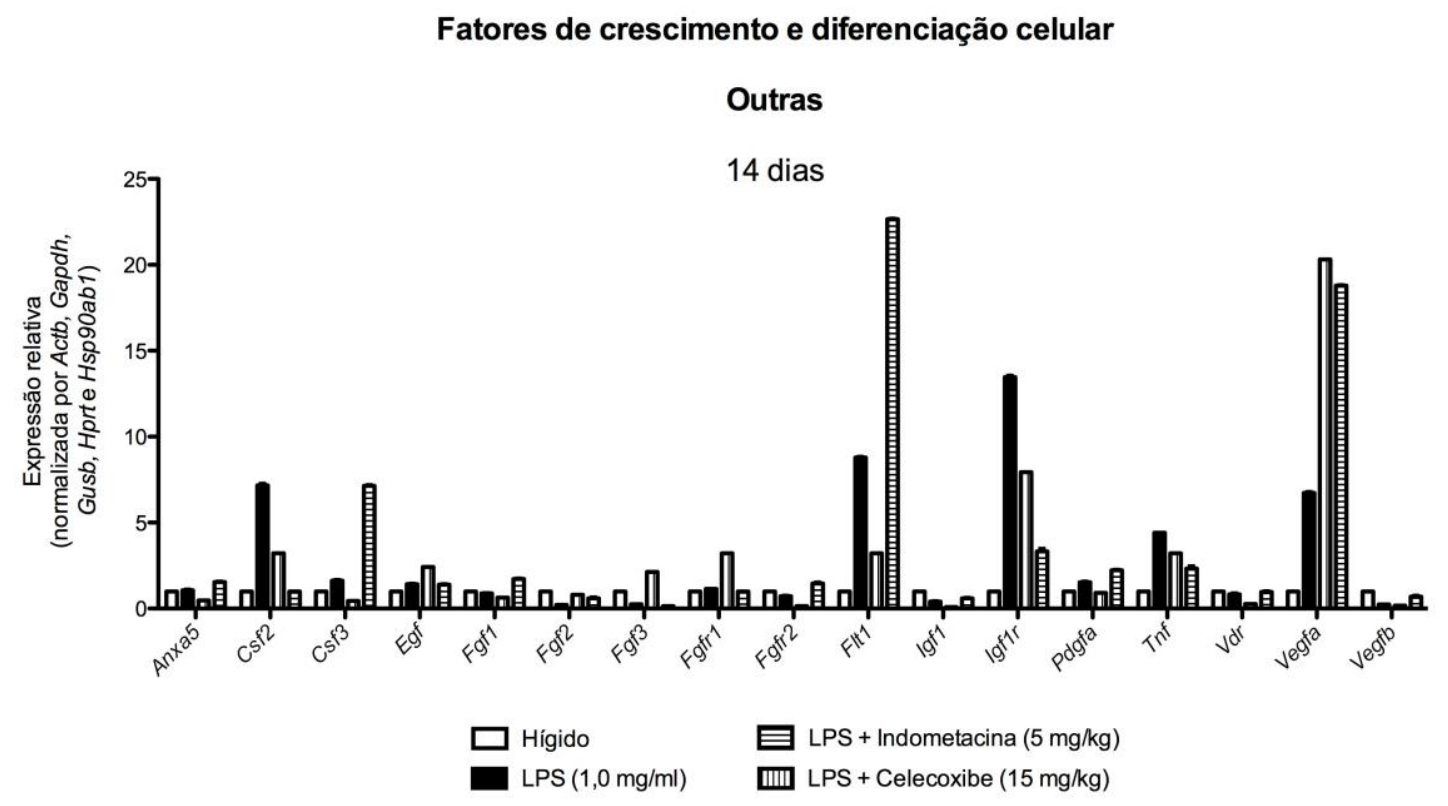

Figura 36. Expressão relativa dos genes que codificam fatores de crescimento aos 14 dias após inoculação de LPS em dentes de camundongos, com e sem administração diária de Indometacina ou Celecoxibe.

\section{Proteínas da matriz extracelular}

\section{Colagênicas}

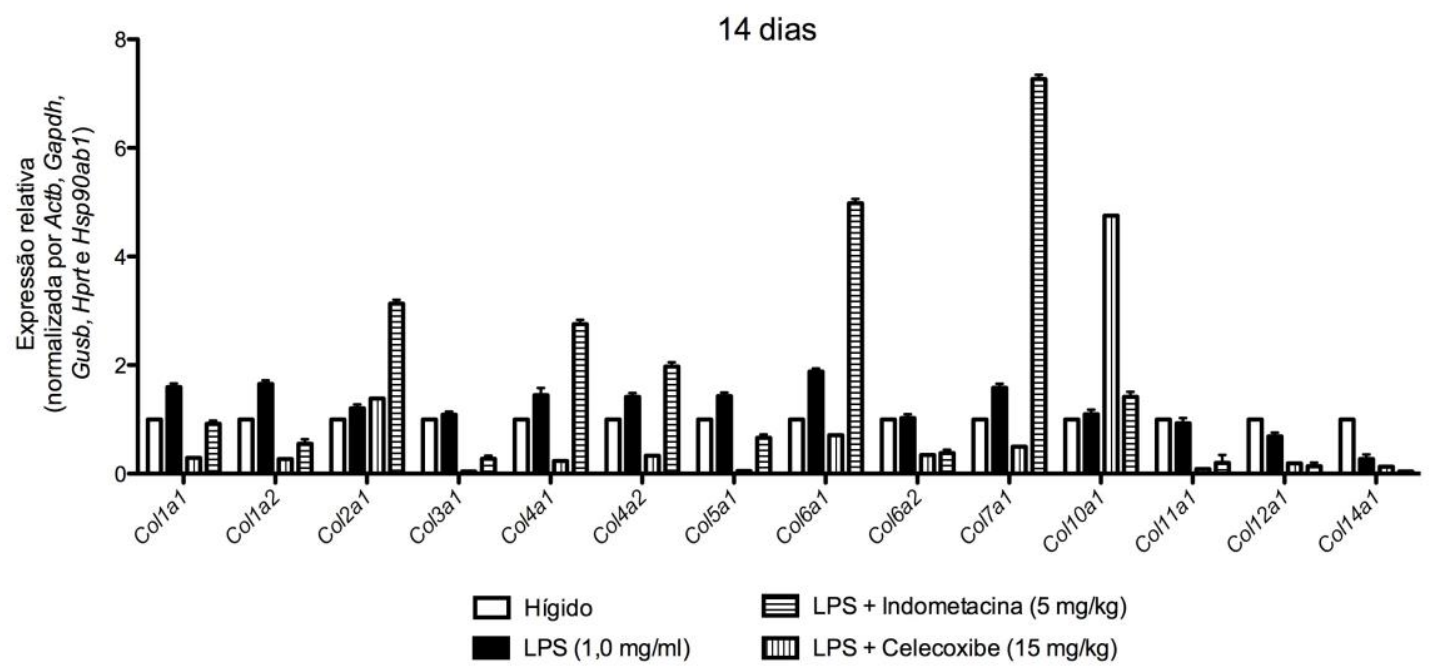

Figura 37. Expressão relativa dos genes que codificam proteínas da matriz extracelular colagênicas aos 14 dias após inoculação de LPS em dentes de camundongos, com e sem administração diária de Indometacina ou Celecoxibe. 


\section{Proteínas da matriz extracelular}

\section{Não colagênicas}

14 dias

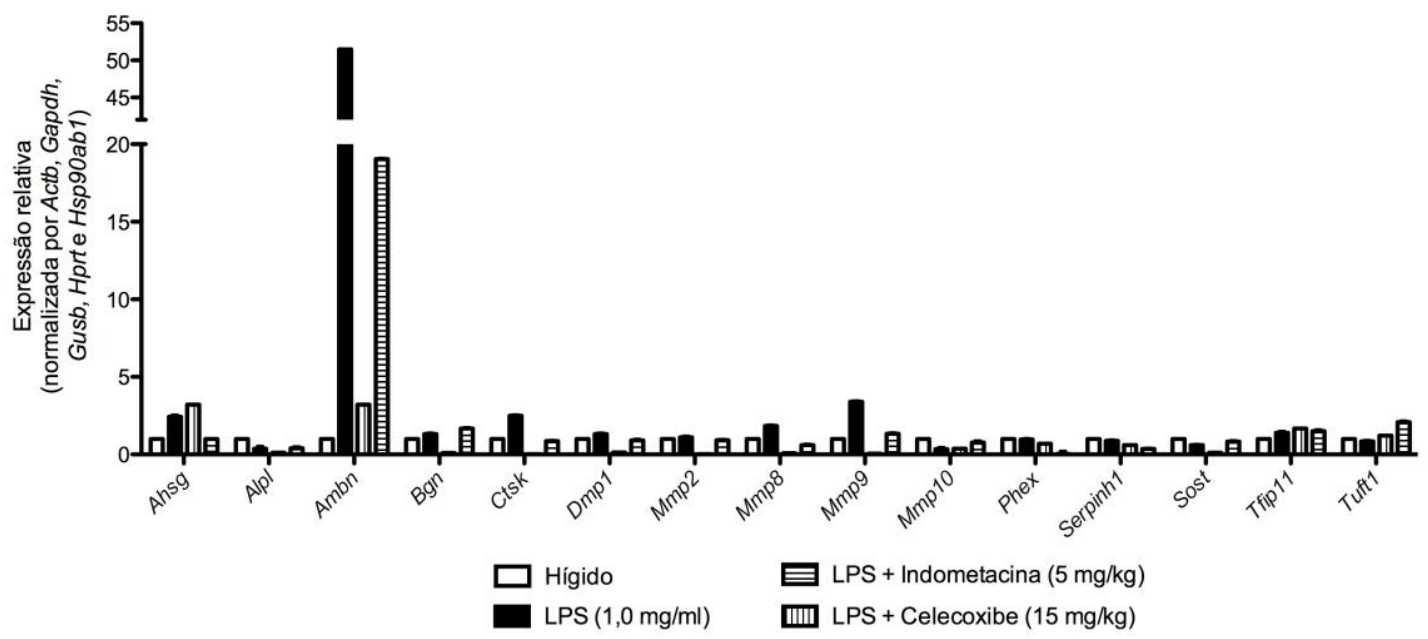

Figura 38. Expressão relativa dos genes que codificam proteínas da matriz extracelular não colagênicas aos 14 dias após inoculação de LPS em dentes de camundongos, com e sem administração diária de Indometacina ou Celecoxibe.

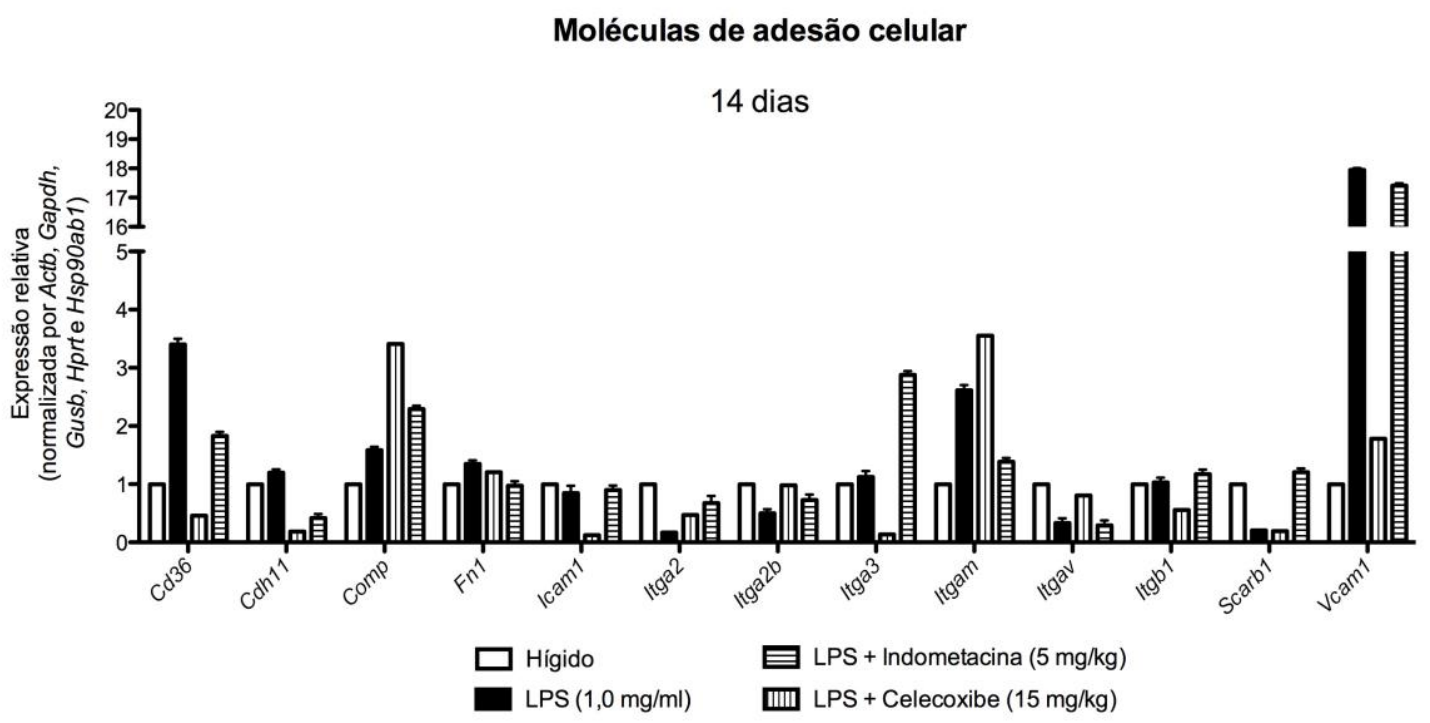

Figura 39. Expressão relativa dos genes que codificam moléculas de adesão celular aos 14 dias após inoculação de LPS em dentes de camundongos, com e sem administração diária de Indometacina ou Celecoxibe. 


\section{Fatores de transcrição}

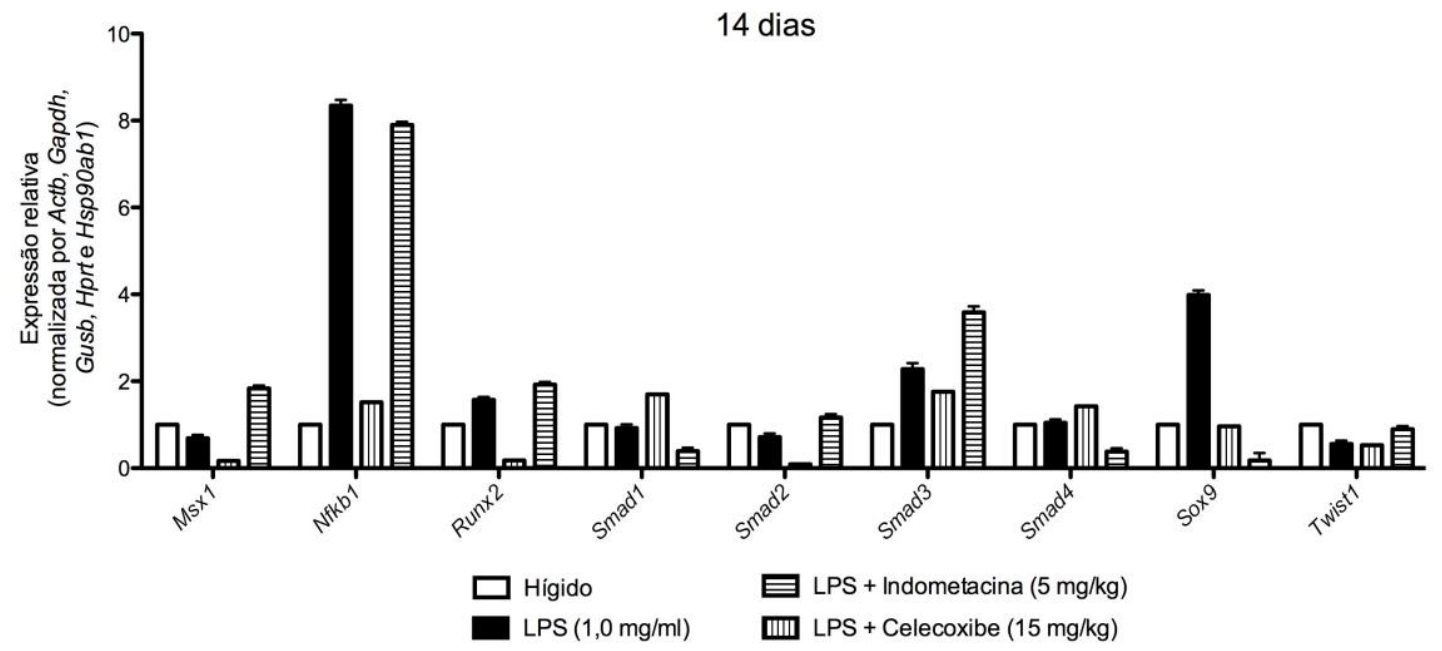

Figura 40. Expressão relativa dos genes que codificam fatores de transcrição aos 14 dias após inoculação de LPS em dentes de camundongos, com e sem administração diária de Indometacina ou Celecoxibe. 
Discussão 

No presente estudo, a inoculação de LPS na câmara pulpar de dentes de camundongos estimulou a expressão do gene $P \operatorname{tgs} 2$, responsável pela codificação da enzima COX-2, envolvida no metabolismo do ácido araquidônico, concomitantemente à modulação da expressão de marcadores da osteoclastogênese e de genes envolvidos no metabolismo ósseo.

O desenvolvimento da lesão periapical foi evidenciado em estudo clássico demonstrando que a exposição pulpar em ratos germ-free não levou a formação de lesão periapical, enquanto em animais convencionais houve desenvolvimento da lesão após 15 dias (Kakehashi et al., 1965). Assim, a presença de bactérias mostrou estimular a resposta inflamatória local e produção intensa de proteases, responsáveis pela degradação do meio extracelular, levando ao processo de reabsorção óssea (Garlet et al., 2006).

Em estudo prévio, demonstrou-se que o LPS foi capaz de induzir a produção de $\mathrm{PGE}_{2}$ por macrófagos (Xiao et al., 2012). Acredita-se que a maioria das ações mediadas pela $\mathrm{PGE}_{2}$ sejam exercidas após ativação de um de seus receptores, que foram denominados receptores EP1, EP2, EP3 e EP4 (Narumiya et al., 1999; Sugimoto and Narumiya, 2007). Estudos de clonagem de cDNA mostraram que todos os receptores EP possuem sete domínios transmembrana característica de receptores acoplados à proteína $\mathrm{G}$, embora cada um deles seja codificado por um gene distinto (Ptger1, Ptger2, Ptger3 e Ptger4), e promovam respostas celulares pela ativação de diferentes tipos de proteína $\mathrm{G}$.

Neste estudo foi observado um aumento na expressão dos receptores Ptger1, Ptger3 e Ptger4 após a inoculação de LPS na câmara pulpar, quando comparados ao grupo controle. Por outro lado, a expressão do receptor Ptger2 após a inoculação de LPS, mantevese semelhante ao grupo controle. Um ponto a ser destacado, considerando a estrutura dos receptores $E P$, é a existência de múltiplas variantes do receptor EP3, que foram denominadas EP3A, EP3B, EP3C e EP3D, e resultam em diferenças cruciais nas vias de sinalização ativadas por cada uma dessas isoformas do receptor EP3, embora apresentem afinidade semelhante pela $\mathrm{PGE}_{2}$ (Sugimoto and Narumiya, 2007). Devido à natureza da investigação realizada neste estudo (qRT-PCR), cuja amostra foi obtida de um macerado de tecido pulpar e ósseo, não foi possível avaliar se a expressão aumentada dos receptores aconteceu no tecido pulpar ou na região periapical.

Os macrófagos, classificados como células mononucleares, são a principal fonte celular responsável pela síntese de prostaglandinas em lesões periapicais. Ainda, numerosos osteoclastos ativos foram observados ao longo da superfície óssea alveolar, 
sugerindo que PGs produzidas pelos macrófagos poderiam ativar os osteoclastos e contribuir para a atividade reabsortiva nas lesões periapicais (Martinho et al., 2012). Neste estudo, foram detectadas um aumento na expressão de RNAm para MMP-9 nos períodos iniciais após inoculação de LPS nos dentes de camundongos, sugerindo o recrutamento de monócitos e diferenciação destas células em macrófagos e osteoclastos. Entretanto, a inibição seletiva ou não da via das ciclo-oxigenases não influenciou a perda óssea induzida pelo lipopolissacarídeo bacteriano. De fato, a inibição não seletiva exacerbou a inflamação periapical e a perda óssea associada, 28 dias após a administração continuada da Indometacina. Como estes resultados não foram mimetizados pelo inibidor seletivo de COX-2 (celecoxibe) sugere-se, portanto, que a via ciclo-oxigenase-1 pode apresentar um papel protetor prevenindo o desenvolvimento da lesão periapical.

Após indução de lesão periapical em ratos, durante 5, 10, 15 e 20 dias, foi observado que macrófagos e osteoblastos mostraram marcações positivas para COX-2, aumentando significativamente a sua expressão durante o decorrer do período analisado. 0 uso de Indometacina e Meloxicam, um inibidor seletivo de COX-2, pôde reduzir significantemente a perda óssea em um modelo de doença periodontal em ratos (Nyman et al., 1979; Bezerra et al., 2000; Gurgel et al., 2004). No presente estudo, foi observado um aumento na marcação de células mononucleares positivas para COX-2, na região de terço cervical do tecido pulpar, com o decorrer do período analisado. Isso pode ser explicado pelo fato do papel crucial dessas células como agente protetor, em resposta à inoculação de LPS.

Nossos resultados demonstram que a inoculação de LPS em dentes de camundongos leva ao aumento de expressão de RANKL, mediador solúvel importante para estimular a osteoclastogênese. Foi demonstrado também, que o tratamento com Indometacina, um inibidor não seletivo de COX-2, resultou numa inibição da expressão de RANKL com aumento da expressão de OPG em períodos precoces de avaliação. Estes resultados, a priori, sugeriam uma possível inibição da reabsorção óssea induzida pelo LPS. Entretanto, foi observado, após 28 dias um aumento da reabsorção óssea, acompanhado por mais produção de RANKL e do receptor RANK. Assim, estes resultados mostram através da expressão gênica, uma inibição da atividade osteoclastogênica durante os períodos iniciais da administração do inibidor não seletivo da via COX-2. E posteriormente, durante o período de 28 dias, uma reversão deste efeito. Diante desses resultados, a utilização clínica de inibidores não seletivos para COX-2, poderia apresentar um resultado benéfico quando utilizado durante os períodos iniciais do processo inflamatório. Esta hipótese ainda está sendo testada em outros estudos realizados por nosso grupo de pesquisa, nos quais 
investigamos o papel dos inibidores seletivo e não-seletivo da enzima ciclooxigenase-2 e da enzima 5-lipoxigenase no tratamento da lesão periapical experimental (Petean, 2015).

Durante o estudo realizado previamente no Curso de Mestrado, observamos que a inoculação de LPS nos canais radiculares de molares de camundongos foi capaz de induzir a expressão do gene Ptgs2, concomitantemente à modulação da expressão dos genes Tnfrsf11a, Tnfsf11 e Tnfrsf11b responsáveis pela codificação dos mediadores da osteoclastogênese RANK, RANKL e OPG, respectivamente. Com a administração de Indometacina, um inibidor não seletivo de COX-2, a expressão de RNAm para RANK e RANKL foi inibida e a expressão de OPG estimulada durante os períodos iniciais de resposta à inoculação de LPS.

Estes resultados indicaram que havia uma sinalização anabólica após o tratamento com a Indometacina em dentes expostos ao LPS. Porém, devido aos efeitos colaterais extensos dos inibidores não seletivos, propusemos este novo trabalho com o objetivo de investigar se os efeitos observados com a Indometacina poderiam ser obtidos com a inibição seletiva de COX-2 por meio do celecoxibe. Aliado a isso, estendemos este estudo para a avaliação histopatológica da região periapical, por meio de histomorfometria, contagem de células inflamatórias e imunohistoquímica. Os resultados analisados através dos cortes histológicos em nosso estudo, mostraram que não houve interferência em relação a presença de reabsorção óssea na região periapical, em dentes com inoculação de LPS e administração dos medicamentos Celecoxibe ou Indometacina, durante todos os períodos experimentais estabelecidos, quando comparados ao grupo em que apenas o LPS foi inoculado. Exceto, durante o período de 28 dias, em animais em que o LPS foi inoculado e administrado Indometacina, onde foi observado um aumento estatisticamente significante da lesão periapical. Sugerindo que a inibição da reabsorção óssea acontece via modulação desses mediadores da osteoclastogênese durante os períodos considerados agudos da inflamação. Divergindo dos nossos resultados, a administração de Indometacina durante o desenvolvimento da lesão periapical resultou em menor intensidade do infiltrado inflamatório concomitantemente a menor reabsorção do tecido ósseo (Oguntebi et al., 1989).

Tendo em vista o pico de expressão de Ptgs2 aos 14 dias do desenvolvimento da lesão periapical, investigamos diversos genes relacionados à osteoclastogênese nos períodos iniciais da lesão, com ou sem inibição seletiva de COX-2. Alguns genes relacionados ao anabolismo ósseo foram estimulados pelo tratamento diário com Indometacina, dentre eles Bmp3, Bmp4, Fgf1, Fgf2, Col2a1, Col4a1, Col4a2, Col6a1, Col7a1, Col10a1 e Col14a1, o receptor $B m p r 1 b$ e o fator de transcrição MsX1. Estes resultados são coerentes com a 
produção dos mediadores da osteoclastogênese RANKL e OPG, nós estágios iniciais da patologia pulpar e desenvolvimento da lesão periapical.

Após indução de lesão periapical em ratos, durante 5, 10, 15 e 20 dias, foi observado que macrófagos e osteoblastos mostraram marcações positivas para COX-2, aumentando significativamente a sua expressão durante o decorrer do período analisado. Após a administração de um inibidor específico para COX-2, Meloxicam, houve uma diminuição em 43\% do grau de reabsorção óssea periapical (Lin et al., 2002). Os resultados analisados através da expressão gênica em nosso estudo, mostraram que houve uma diminuição na expressão dos genes responsáveis pela codificação de RANK e RANKL durante o período de 7 dias e um aumento aos 28 dias. Da mesma forma, genes relacionados a formação óssea foram estimulados pelo tratamento diário com Celecoxibe durante os períodos iniciais, dentre eles Col14a1, Ahsg, Itga2, Itgam, o receptor Bmpr1b e o fator de transcrição MsX1.

Concentrações significativamente mais elevadas de $\mathrm{PGE}_{2}$ foram encontradas em lesões agudas quando comparados às lesões crônicas, confirmando o papel das PGs na patogênese de lesões periapicais em humanos (McNicholas et al., 1991; Shimauchi et al., 1997; Alptekin et al., 2005). O aumento da síntese de $\mathrm{PGE}_{2}$ em dentes com inflamação periapical está relacionado com alterações inflamatórias e catabólicas que ocorrem em lesões periapicais (Martinho et al., 2011) e a diminuição da produção de $\mathrm{PGE}_{2}$ pode ser considerada um indicativo de remissão da doença (Shimauchi et al., 1997).

A expressão do RNAm para RANK, RANKL e OPG foi investigada por RT-PCR, em lesões periapicais induzidas em primeiros molares inferiores de ratos, deixados abertos ao meio bucal por 1, 2, 3, 4 e 8 semanas (Kawashima et al., 2007). Duas semanas após a indução da lesão periapical foi observada expressão aumentada de RANKL, com pico de expressão na terceira semana. As cinéticas da expressão de RANK e OPG foram semelhantes a de RANKL, ocorrendo um aumento da razão entre RANKL / OPG na segunda e terceira semana. Concomitante a esse achado, a expressão das citocinas pró-inflamatórias também aumentou nesse estágio, sugerindo o efeito sinérgico do RANKL e das citocinas próinflamatórias para a progressão das lesões periapicais. O início do processo de reabsorção óssea nas lesões periapicais associado ao aumento da expressão de RANK, indica a diferenciação de osteoclastos, células que apresentam este receptor de superfície (Sabeti et al., 2005; Vernal et al., 2006; Kawashima et al., 2007).

$\mathrm{Na}$ inflamação, algumas células são fundamentais, dentre elas os leucócitos, que podem ser divididos em polimorfonucleares e mononucleares. Os polimorfonucleares são considerados participantes mais ativos nos processos de inflamações agudas, representados 
principalmente pelos neutrófilos. As células mononucleadas, por outro lado, são consideradas típicas da inflamação crônica, representadas principalmente pelos macrófagos (Consolaro, 2009). Nas diferentes fases do desenvolvimento da lesão periapical é possível identificar alguns tipos celulares, com o predomínio de células polimorfonucleadas até o período de 90 dias após a indução experimental (Pinto, 2006). Em nosso estudo, durante os períodos experimentais de 21 e 28 dias, no tecido periapical, foi observada diferença estatisticamente significante entre o percentual de células mononucledas e polimorfonucleadas, após a inoculação de LPS na câmara pulpar, com um predomínio de células polimorfonucleadas.

Quando lesões periapicais foram induzidas em molares de ratos, estas apresentavam predomínio de macrófagos em todos os períodos experimentais. O número de linfócitos aumentou antes do início da fase ativa da lesão (Kawashima et al., 1996). As lesões periapicais induzidas experimentalmente em ratos, desenvolvem-se rapidamente entre os dias 0 e 15 dias, e mais lentamente nos períodos subsequentes, quando a microbiota anaeróbia e gram-negativa, semelhante àquela observada em humanos, rapidamente se estabelece. Essas lesões contêm um infiltrado celular inflamatório misto consistindo de linfócitos T, neutrófilos, linfócitos B, macrófagos e plasmócitos (Pinto, 2006).

Tanto com a administração de um inibidor seletivo para COX-2, como não seletivo, foi observado durante todos os períodos experimentais um aumento no percentual de células mononucleadas, tanto na região do tecido pulpar, como periapical. Este fato sugere a presença de um percentual celular de macrófagos aumentado, corroborando com os achados nos quais as lesões periapicais induzidas em molares de ratos apresentavam predomínio de macrófagos em todos os períodos experimentais (Kawashima et al., 1996).

Diante do exposto, é necessário o conhecimento do papel da via ciclooxigenase na inflamação pulpar e reabsorção óssea periapical, não só através da expressão gênica de mediadores da osteoclastogênese e genes envolvidos no metabolismo ósseo, como da avaliação histométrica, identificação de células inflamatórias e marcação de células para COX-2, após inoculação de LPS na câmara pulpar de molares de camundongos, com o seu posterior bloqueio. Entretanto estudos são necessários para revelar os componentes e funções da grande rede de mediadores, relacionados e envolvidos com a evolução da lesão periapical e consequente destruição óssea. 

Conclusóes 

De acordo com os resultados obtidos neste estudo podemos concluir que:

- A inoculação de LPS na câmara pulpar de dentes de camundongos foi capaz de induzir a expressão do gene Ptgs2, da proteína COX-2 bem como dos receptores Ptger1, Ptger3 e Ptger4 para PGE $_{2}$;

- A administração de Indometacina ou Celecoxibe não preveniram a perda óssea durante o desenvolvimento da lesão periapical, ainda que a Indometacina tenha inibido a sinalização precoce para a osteoclastogênese;

- O tratamento com Indometacina e Celecoxibe resultaram em desfechos distintos da lesão periapical, uma vez que o inibidor seletivo não inibiu a perda óssea e o inibidor não seletivo exacerbou o catabolismo ósseo periapical. Tendo em vista que Celecoxibe e Indometacina modularam diferencialmente a expressão de genes envolvidos no metabolismo ósseo após inoculação de LPS, parece existir um papel distinto para COX-1 e COX-2 no desenvolvimento da lesão periapical. 

Referentias*

* Normas internas do Programa de Pós-Graduação em Odontopediatria da FORP-USP (2009), de acordo com o International Committee of Medicals Journals Editors. Uniform Requirements for manuscripts submitted to Medical Journal, 2014. Disponível em: http://www.icmje.org. Acesso em 5 de fevereiro de 2015. 



\section{REFERÊNCIAS}

Abbas AK, Lichtman AH, Pillai S, Farias AS. Imunologia celular e molecular. 6 ed. Rio de Janeiro: Editora Elsevier; 2008.

Alptekin NO, Ari H, Haliloglu S, Alptekin T, Serpek B, Ataoglu T. The effect of endodontic therapy on periapical exudate neutrophil elastase and prostaglandin-E2 levels. J Endod 2005;31(11):791-5.

Anandarajah AP. Role of RANKL in bone diseases. Trends Endocrinol Metab 2009;20(2):8894.

Bar-Shavit Z. The osteoclast: a multinucleated, hematopoietic-origin, bone-resorbing osteoimmune cell. J Cell Biochem 2007;102(5):1130-9.

Bezerra MM, de Lima V, Alencar VB, Vieira IB, Brito GA, Ribeiro RA, et al. Selective cyclooxygenase- 2 inhibition prevents alveolar bone loss in experimental periodontitis in rats. J Periodontol 2000;71(6):1009-14.

Boyle WJ, Simonet WS, Lacey DL. Osteoclast differentiation and activation. Nature 2003;423(6937):337-42.

Charlier C, Michaux C. Dual inhibition of cyclooxygenase-2 (COX-2) and 5-lipoxygenase (5LOX) as a new strategy to provide safer non-steroidal anti-inflammatory drugs. European Journal of Medicinal Chemistry 2003;38(7-8):645-59.

Claria J, Romano M. Pharmacological intervention of cyclooxygenase-2 and 5-lipoxygenase pathways. Impact on inflammation and cancer. Curr Pharm Des 2005;11(26):3431-47.

Claria J. Cyclooxygenase-2 biology. Curr Pharm Des 2003;9(27):2177-90.

Consolaro, A. Inflamação e reparo. 1 ed. Maringá: Editora Dental Press; 2009.

De Rossi A, Rocha LB, Rossi MA. Interferon-gamma, interleukin-10, Intercellular adhesion molecule-1, and chemokine receptor 5, but not interleukin-4, attenuate the development of periapical lesions. J Endod 2008;34(1):31-8.

Fiorucci S, Meli R, Bucci M, Cirino G. Dual inhibitors of cyclooxygenase and 5-lipoxygenase. A new avenue in anti-inflammatory therapy? Biochem Pharmacol 2001;62(11):1433-8.

Gallagher JC. Advances in bone biology and new treatments for bone loss. Maturitas 2008;60(1):65-9.

Garlet GP, Cardoso CR, Silva TA, Ferreira BR, Avila-Campos MJ, Cunha FQ, Silva JS. Cytokine pattern determines the progression of experimental periodontal disease induced by Actinobacillus actinomycetemcomitans through the modulation of MMPs, RANKL, and their physiological inhibitors. Oral Microbiol Immunol 2006;21(1):12-20.

Gonzalez-Periz A, Claria J. New approaches to the modulation of the cyclooxygenase-2 and 5-lipoxygenase pathways. Curr Top Med Chem 2007;7(3):297-309.

Graunaite I, Lodiene G, Maciulskiene V. Pathogenesis of Apical Periodontitis: a Literature Review. Journal of oral \& Maxillofacial Research 2011; 2(4). 
Gurgel BC, Duarte PM, Nociti FH, Jr., Sallum EA, Casati MZ, Sallum AW, et al. Impact of an anti-inflammatory therapy and its withdrawal on the progression of experimental periodontitis in rats. J Periodontol 2004;75(12):1613-8.

Holzhausen M, Marcantonio Jr E, Spolidorio DMP, Spolidorio LC. Efeito do celecoxibe sobre a resposta inflamatória em doença periodontal experimental: estudo histológico em ratos. Periodontia 2009;19(2):86-92.

Jankovic D, Liu Z, Gause WC. Th1- and Th2-cell commitment during infectious disease: asymmetry in divergent pathways. Trends Immunol 2001;22(8):450-7.

Jin Q, Cirelli JA, Park CH, Sugai JV, Taba M, Jr., Kostenuik PJ, et al. RANKL inhibition through osteoprotegerin blocks bone loss in experimental periodontitis. J Periodontol 2007;78(7):1300-8.

Kakehashi S, Stanley HR, Fitzgerald RJ. The effects of surgical exposures of dental pulps in germ-free and conventional laboratory rats. Oral Surg Oral Med Oral Pathol 1965;20:340-9.

Kawashima M, Fujikawa Y, Itonaga I, Takita C, Tsumura H. The effect of selective cyclooxygenase-2 inhibitor on human osteoclast precursors to influence osteoclastogenesis in vitro. Mod Rheumatol 2009; 19: 192-198.

Kawashima N, Okiji T, Kosaka T, Suda H. Kinects of macrophages and lymphoide cells during the development of experimentally induced periapical lesions in rat molars: a quantitative immunohistochemical study. J Endod 1996; 22:311-316.

Kawashima N, Suzuki N, Yang G, Ohi C, Okuhara S, Nakano-Kawanishi H, et al. Kinetics of RANKL, RANK and OPG expressions in experimentally induced rat periapical lesions. Oral Surg Oral Med Oral Pathol Oral Radiol Endod 2007;103(5):707-11.

Kearns $\mathrm{AE}$, Khosla S, Kostenuik PJ. Receptor activator of nuclear factor kappaB ligand and osteoprotegerin regulation of bone remodeling in health and disease. Endocr Rev 2008;29(2):155-92.

Kovác J, Kovác D. Histopathology and etiopathogenesis of chronic apical periodontitisperiapical granuloma. Epidemiol Mikrobiol Imunol 2011; 60(2): 77-86.

Lange U, Teichmann J, Schett G, Neumann E, Müller-Ladner U. Osteoimmunology: how inflammation influences bone metabolism. Dtsch Med Wochenschr. 2013; 138(37):1845-9.

Lau YS, Sabokbar A, Gibbons CLMH, Giele H, Athanasou N. Phenotypic and molecular studies of giant-cell tumors of bone and soft tissue. Human pathology 2005;36(9):945-54.

Lee YL, Liu J, Clarkson BH, Lin CP, Godovikova V, Ritchie HH. Dentin-pulp complex responses to carious lesions. Caries Res 2006;40(3):256-64.

Leibbrandt $A$, Penninger JM. RANK/RANKL: regulators of immune responses and bone physiology. Ann N Y Acad Sci 2008;1143:123-50.

Leonardo MR, Silva RAB, Assed S, Nelson-Filho P. Importance of Bacterial Endotoxin (LPS) in Endodontics. J Appl Oral Sci 2004;12(2):93-8. 
Lerner UH. New molecules in the tumor necrosis factor ligand and receptor superfamilies with importance for physiological and pathological bone resorption. Crit Rev Oral Biol Med 2004;15(2):64-81.

Liapatas S, Nakou M, Rontogianni D. Inflammatory infiltrate of chronic periradicular lesions: an immunohistochemical study. Int Endod J 2003;36(7):464-71.

Lin SK, Kok SH, Kuo MY, Wang TJ, Wang JT, Yeh FT, et al. Sequential expressions of MMP-1, TIMP-1, IL-6, and COX-2 genes in induced periapical lesions in rats. Eur J Oral Sci 2002;110(3):246-53.

Liu L, Peng B. The expression of macrophage migration inhibitory factor is correlated with receptor activator of nuclear factor kappa $b$ ligand in induced rat periapical lesions. Journal of Endodontics. 2013; 39(8):984-989.

Machado ER, Carlos D, Lourenço EV, Souza GEP, Sorgi CA, Silva EV, Ueta MT, Ramos SG, Aronoff DM, Faccioli LH. Cyclooxygenase-derived mediators regulate the immunological control of Strongyloides venezuelensis infection. FEMS Immunol Med Microbiol 2010; 59(1):18-32

Martinho FC, Chiesa WM, Leite FR, Cirelli JA, Gomes BP. Antigenicity of primary endodontic infection against macrophages by the levels of PGE(2) production. J Endod 2011;37(5):6027.

Martinho FC, Chiesa WMM, Leite FRM, Cirelli JÁ, Gomes BPFA. Correlation between Clinical/Radiographic Features and Inflammatory Cytokine Networks Produced by Macrophages Stimulated with Endodontic Content. J Endod 2012; 38(6):740-745.

Marton IJ, Kiss C. Protective and destructive immune reactions in apical periodontitis. Oral Microbiol Immunol 2000;15(3):139-50.

Massoumi $\mathrm{R}$, Sjolander $\mathrm{A}$. The role of leukotriene receptor signaling in inflammation and cancer. Scientific World Journal 2007;7:1413-21.

McNicholas S, Torabinejad M, Blankenship J, Bakland L. The concentration of prostaglandin E2 in human periradicular lesions. J Endod 1991;17(3):97-100.

Menezes-Silva R, Khaliq S, Deeley K, Letra A, Vieira AR. Genetic susceptibility to periapical disease: conditional contribution of $\mathrm{mmp} 2$ and $\mathrm{mmp} 3$ genes to the development of periapical lesions and healing response. Journal of Endodontics. 2012; 38(5):604-607.

Metzger $\mathrm{Z}$, Klein $\mathrm{H}$, Klein A, Tagger M. Periapical lesion development in rats inhibited by dexamethasone. J Endod 2002;28(9):643-5.

Naidu VGM, Babu KRD, Thwin MM, Satish RL, Kumar PV, Gopalakrishnakone P. RANKL targeted peptides inhibit osteoclastogenesis and attenuate adjuvant induced arthritis by inhibiting NF- kB activation and down regulating inflammatory cytokines. Chemico-Biological Interactions 2013; 203: 467-479.

Narumiya S, Sugimoto Y, Ushikubi F. Prostanoid Receptors: Structures , properties, and functions. Physiol Rev 1999;70:1193-1226.

Neumann E, Müller-Ladner U, Frommer KW. Inflammation and bone metabolism. Z Rheumatol. 2014; 73(4):342-8. 
Nyman S, Schroeder HE, Lindhe J. Suppression of inflammation and bone resorption by indomethacin during experimental periodontitis in dogs. J Periodontol 1979;50(9):450-61.

Oguntebi BR, Barker BF, Anderson DM, Sakumura J. The effect of indomethacin on experimental dental periapical lesions in rats. J Endod 1989;15(3):117-21.

Paula-Silva FW, Ghosh A, Silva LA, Kapila YL. TNF-alpha promotes an odontoblastic phenotype in dental pulp cells. J Dent Res 2009d; 88(4):339-44.

Paula-Silva FW, Silva LA, Kapila YL. Matrix metalloproteinase expression in teeth with apical periodontitis is differentially modulated by the modality of root canal treatment. J Endod 2010; 36(2):231-7.

Paula-Silva FWG, D'Silva NJ, Silva LAB, Kapila YL. High matrix metalloproteinase activity is a hallmark of periapical granulomas. J Endod 2009a;35:1234-42.

Paula-Silva FWG, Santamaria-Junior M, Leonardo MR, Consolaro A, Silva LAB. Cone-beam computerized tomographic, radiographic, and histologic evaluation of periapical repair in dogs' post-endodontic treatment. Oral Surg Oral Med Oral Pathol Oral Radiol Endod 2009c; 108:796-805.

Paula-Silva FWG, Wu M-K, Silva LAB, Leonardo MR, Wesselink PR. Accuracy of periapical radiography and cone-beam computed tomography in diagnosing apical periodontitis using histopathological findings as a gold standard. J Endod 2009b; 35(7):1009-12.

Petean, IBF ; Santos, FRR ; Silva, LAB ; Paula-Silva, FWG. Contaminação bucal versus lipopolissacarídeo bacteriano: metodologias para indução da lesão periapical experimental. In: $22^{\circ}$ Simpósio Internacional de Iniciação Científica da USP , 2014, São Paulo.

Pidgeon GP, Lysaght J, Krishnamoorthy S, Reynolds JV, O'Byrne K, Nie D, et al. Lipoxygenase metabolism: roles in tumor progression and survival. Cancer Metastasis Rev 2007;26(3-4):503-24.

Pinto, LC. Estudo radiográfico e miscroscópico de lesões periapicais inflamatórias induzidas em ratos. Dissertação (Mestrado). Faculdade de Odontologia deBauru: Universidade de São Paulo 2016; $109 f$.

Prahlad AS, Sharad K, Puranik RS, Surekha P, Saraf SP, Singh BP. Comparative evaluation of immunohistochemistry, histopathology and conventional radiography in differentiating periapical lesions. J Conserv Dent. 2014; 17(2):164-168.

Rietschel ET, Brade H.Bacterial endotoxins. Sci Am 1992; 267(2):54-61.

Robbins SL, Kumar V, Cotran RS. Robbins and Cotran pathologic basis of disease. 8th ed. Philadelphia, PA: Saunders/Elsevier; 2010.

Sabeti M, Simon J, Kermani V, Valles Y, Rostein I. Detection of receptor activator of NFkappa beta ligand in apical periodontitis. J Endod 2005;31(1):17-8. 
Santos FRR. Ciclooxigenase- 2 modula in vivo a expressão de marcadores da osteoclastogênese e genes envolvidos no metabolismo ósseo em resposta ao lipopolissacarídeo bacteriano. Dissertação (Mestrado). Faculdade de Odontologia de Ribeirão Preto: Universidade de São Paulo 2012; 74f.

Santos FRR. Ciclooxigenase-2 modula in vivo a expressão de marcadores da osteoclastogênese e genes envolvidos no metabolismo ósseo em resposta ao lipopolissacarídeo bacteriano. Dissertação (Mestrado). Faculdade de Odontologia de Ribeirão Preto: Universidade de São Paulo 2012; 74f.

Shimauchi H, Takayama S, Miki Y, Okada $\mathrm{H}$. The change of periapical exudate prostaglandin E2 levels during root canal treatment. J Endod 1997;23(12):755-8.

Silva LAB, Silva RAB, Branco LGS, Navarro VP, Nelson-Filho P. Quantitative Radiographic Evaluation of Periapical Bone Resorption in Dog's Teeth Contaminated With Bacterial Endotoxin (LPS) Associated or not with Calcium Hydroxide. Braz Dent J 2008; 19(4):296-300.

Steinhilber D, Fischer AS, Metzner J, Steinbrink SD, Roos J, Ruthardt M, et al. 5lipoxygenase: underappreciated role of a pro-inflammatory enzyme in tumorigenesis. Front Pharmacol 2010;1:143.

Sugimoto $\mathrm{Y}$ and Narumiya S. Prastaglandin E Receptors. The Journal of biological chemistry 2007; 282(16):11613-11617.

Suzuki T, Kumamoto H, Ooya K, Motegi K. Expression of inducible nitric oxide synthase and heat shock proteins in periapical inflammatory lesions. J Oral Pathol Med 2002;31(8):488-93.

Tay JY, Bay BH, Yeo JF, Harris M, Meghji S, Dheen ST. Identification of RANKL in osteolytic lesions of the facial skeleton. J Dent Res 2004;83(4):349-53.

Torabinejad M, Cotti $E$, Jung $T$. Concentrations of leukotriene B4 in symptomatic and asymptomatic periapical lesions. J Endod 1992;18(5):205-8.

Trouvin AP, Goeb V. Receptor activator of nuclear factor-kappaB ligand and osteoprotegerin: maintaining the balance to prevent bone loss. Clin Interv Aging 2010;5:345-54.

Vardar S, Buduneli E, Baylas $\mathrm{H}$, Berdeli AH, Buduneli N, Atilla G. Individual and combined effects of selective cyclooxygenase-2 inhibitor and omega-3 fatty acid on endotoxin-induced periodontitis in rats. J Periodontol 2005;76(1):99-106.

Vernal R, Dezerega A, Dutzan N, Chaparro A, Leon R, Chandia S, et al. RANKL in human periapical granuloma: possible involvement in periapical bone destruction. Oral Dis 2006;12(3):283-9.

Virtej A, Loes SS, Berggreen E, Bletsa A. Localization and signaling patterns of vascular endothelial growth factors and receptors in human periapical lesions. J Endod 2013; 39(5): 605-611.

Wan C, Yuan G, Yang J, Sun Q, Zhang L, Zhang J, Zhang L, Chen Z. MMP9 Deficiency increased the size of experimentally induced apical periodontitis. J Endod. 2014; 40(8):65864. 
Xiao L, Ornatowska M, Zhao G, Cao H, Yu H, Deng J, Li Y, Zhao Q, Sadikot RT, Christman JW. Lipopolysaccharide induced expression of microsomal prostaglandin $E$ synthase-1 mediates late-phase PGE2 production in bone marrow derived macrophages. Plos one 2012;7(11):1-13.

Zhang F, Engebretson SP, Morton RS, Cavanaugh PF, Jr., Subbaramaiah K, Dannenberg AJ. The overexpression of cyclo-oxygenase-2 in chronic periodontitis. J Am Dent Assoc 2003; 134(7):861-7. 


\section{Apêndice}



Quadro 1. Genes avaliados no PCR Array para proteínas envolvidas no metabolismo ósseo, nomenclatura da proteína traduzida, principal função descrita e características específicas

\begin{tabular}{|c|c|c|c|}
\hline Gene & Nomenclatura & Função & Característica específica \\
\hline$B m p 1$ & $\begin{array}{l}\text { Proteína óssea } \\
\text { morfogenética } 1\end{array}$ & $\begin{array}{l}\text { Fator de } \\
\text { crescimento }\end{array}$ & $\begin{array}{c}\text { Este gene codifica uma metaloproteinase que é } \\
\text { essencial para a formação da matriz extracelular e é } \\
\text { capaz de induzir a formação de osso ectópico. A } \\
\text { proteína codificada não está intimamente relacionada } \\
\text { com fator de crescimento transformador- } \beta \text { (TGF- } \beta \text { ), } \\
\text { ao contrário de outras proteínas morfogenéticas do } \\
\text { osso. }\end{array}$ \\
\hline Bmp2 & $\begin{array}{l}\text { Proteína óssea } \\
\text { morfogenética } 2\end{array}$ & $\begin{array}{l}\text { Fator de } \\
\text { crescimento }\end{array}$ & $\begin{array}{l}\text { Este gene codifica um membro de uma família de } \\
\text { fatores que participam na transdução do sinal para } \\
\text { estimular o desenvolvimento. A proteína codificada é } \\
\text { capaz de induzir a formação de osso e cartilagem. }\end{array}$ \\
\hline Bmp3 & $\begin{array}{l}\text { Proteína óssea } \\
\text { morfogenética } 3\end{array}$ & $\begin{array}{l}\text { Fator de } \\
\text { crescimento }\end{array}$ & $\begin{array}{l}\text { BMP3 pertence ao fator de crescimento TGF } \beta \text {. } \\
\text { Proteína morfogenética também conhecida como } \\
\text { osteogenina, induz a formação de osso. }\end{array}$ \\
\hline Bmp4 & $\begin{array}{l}\text { Proteína óssea } \\
\text { morfogenética } 4\end{array}$ & $\begin{array}{l}\text { Fator de } \\
\text { crescimento }\end{array}$ & $\begin{array}{c}\text { Este membro da família tem um papel importante no } \\
\text { aparecimento de formação óssea endocondral em } \\
\text { seres humanos. Sua redução na expressão tem sido } \\
\text { associada a uma variedade de doenças ósseas, } \\
\text { incluindo a desordem hereditária Fibrodisplasia } \\
\text { Ossificante Progressiva. }\end{array}$ \\
\hline Bmp6 & $\begin{array}{l}\text { Proteína óssea } \\
\text { morfogenética } 6\end{array}$ & $\begin{array}{l}\text { Fator de } \\
\text { crescimento }\end{array}$ & $\begin{array}{l}\text { As proteínas morfogenéticas do osso (BMPs) são uma } \\
\text { família de moléculas de sinalização segregadas que } \\
\text { podem induzir o crescimento do osso ectópico. A BMP } \\
\text { codificada por este gene tem um papel proposto no } \\
\text { início do desenvolvimento. }\end{array}$ \\
\hline Bmprla & $\begin{array}{l}\text { Receptor para proteína óssea } \\
\text { morfogenética, tipo } 1 \mathrm{~A}\end{array}$ & $\begin{array}{l}\text { Fator de } \\
\text { crescimento }\end{array}$ & $\begin{array}{l}\text { Os receptores de proteína morfogenética óssea (BMP) } \\
\text { são uma família de serina- treonina-quinases, que } \\
\text { incluem o tipo de receptores que BMPR1A e BMPR1B } \\
\text { e o receptor BMPR2 tipo II. }\end{array}$ \\
\hline Bmpr1b & $\begin{array}{l}\text { Receptor para proteína óssea } \\
\text { morfogenética, tipo 1B }\end{array}$ & $\begin{array}{l}\text { Fator de } \\
\text { crescimento }\end{array}$ & $\begin{array}{l}\text { Este gene codifica um membro da família de } \\
\text { receptores da proteína morfogenética óssea (BMP). } \\
\text { BMPs estão envolvidos na formação óssea } \\
\text { endocondral e embriogénese. }\end{array}$ \\
\hline Tgfb1 & $\begin{array}{l}\text { Fator de crescimento } \\
\text { transformador- } \beta 1\end{array}$ & $\begin{array}{l}\text { Fator de } \\
\text { crescimento }\end{array}$ & $\begin{array}{l}\text { Este gene codifica um membro do fator de } \\
\text { crescimento transformador- } \beta \text {, que são peptídeos } \\
\text { multifuncionais que regulam a proliferação, } \\
\text { diferenciação, adesão, migração, e outras funções em } \\
\text { muitos tipos de células. Muitas células têm receptores } \\
\text { para TGF } \beta \text {, e a proteína regula muitos outros fatores } \\
\text { de crescimento. Este gene é frequentemente regulado } \\
\text { nas células tumorais. }\end{array}$ \\
\hline Tgfb2 & $\begin{array}{l}\text { Fator de crescimento } \\
\text { transformador- } \beta 2\end{array}$ & $\begin{array}{l}\text { Fator de } \\
\text { crescimento }\end{array}$ & $\begin{array}{l}\text { Este gene codifica um membro do fator de } \\
\text { crescimento transformador- } \beta \text { (TGFB), que são } \\
\text { peptídeos multifuncionais que regulam a proliferação, } \\
\text { diferenciação, adesão, migração, e outras funções em } \\
\text { muitos tipos de células. Perturbação da via TGF- } \beta \text { / } \\
\text { SMAD tem sido implicada numa variedade de } \\
\text { cânceres humanos. A proteína codificada é segregada } \\
\text { e tem efeitos supressores de interleucina- } 2 \text { de } \\
\text { crescimento de células T dependente. }\end{array}$ \\
\hline $\operatorname{Tgfb3}$ & $\begin{array}{l}\text { Fator de crescimento } \\
\text { transformador- } \beta 3\end{array}$ & $\begin{array}{l}\text { Fator de } \\
\text { crescimento }\end{array}$ & $\begin{array}{c}\text { Este gene codifica um membro da família TGF- } \beta \text { de } \\
\text { proteínas. A proteína codificada é secretado e está } \\
\text { envolvido na embriogênese e na diferenciação celular. } \\
\text { Defeitos neste gene causa displasia arritmogênica do } \\
\text { ventrículo direito. }\end{array}$ \\
\hline Tgfbr 1 & $\begin{array}{l}\text { Receptor para o fator de } \\
\text { crescimento transformador, } \\
\text { beta } 1\end{array}$ & $\begin{array}{l}\text { Fator de } \\
\text { crescimento }\end{array}$ & $\begin{array}{l}\text { Mutações neste gene estão associadas com a } \\
\text { síndrome de aneurisma aórtico Loeys-Dietz (LDAS). } \\
\text { Várias variantes transcritos que codificam diferentes } \\
\text { isoformas foram encontradas por este gene. }\end{array}$ \\
\hline
\end{tabular}




\begin{tabular}{|c|c|c|c|}
\hline Tgfbr2 & $\begin{array}{l}\text { Receptor para o fator de } \\
\text { crescimento transformador, } \\
\text { beta } 2\end{array}$ & $\begin{array}{l}\text { Fator de } \\
\text { crescimento }\end{array}$ & $\begin{array}{c}\text { Este complexo receptor / ligante, translocam para o } \\
\text { núcleo e regulam a transcrição de um subconjunto de } \\
\text { genes relacionados com a proliferação celular. } \\
\text { Mutações nesse gene têm sido associadas com a } \\
\text { Síndrome de Marfan, Loeys-Deitz Síndrome de } \\
\text { aneurisma da aorta e para o desenvolvimento de } \\
\text { vários tipos de tumores. }\end{array}$ \\
\hline Tgfbr3 & $\begin{array}{c}\text { Receptor para o fator de } \\
\text { crescimento transformador, } \\
\text { beta } 3\end{array}$ & $\begin{array}{l}\text { Fator de } \\
\text { crescimento }\end{array}$ & $\begin{array}{l}\text { O receptor codificado é um proteoglicano de } \\
\text { membrana que funciona frequentemente como um } \\
\text { co-receptor com os outros membros da superfamília } \\
\text { do receptor de TGF- } \beta \text {. Redução da expressão deste } \\
\text { receptor tem sido observado em vários cânceres. }\end{array}$ \\
\hline Gdf10 & $\begin{array}{l}\text { Fator } 10 \text { de diferenciação de } \\
\text { crescimento }\end{array}$ & $\begin{array}{l}\text { Fator de } \\
\text { crescimento }\end{array}$ & $\begin{array}{l}\text { Os membros desta família são os reguladores de } \\
\text { crescimento e diferenciação celular em ambos os } \\
\text { tecidos embrionários e adultos. Estudos em ratos } \\
\text { sugerem que a proteína codificada por este gene } \\
\text { desempenha um papel na morfogénese esquelético. }\end{array}$ \\
\hline Anxa5 & Anexina A5 & $\begin{array}{l}\text { Fatores de } \\
\text { crescimento }\end{array}$ & $\begin{array}{l}\text { A proteína codificada por este gene pertence à família } \\
\text { da anexina dependentes de cálcio, as proteínas de } \\
\text { ligação de fosfolipídeos, alguns dos quais têm sido } \\
\text { implicados em eventos relacionados com a membrana } \\
\text { ao longo de vias exocitose e endocitose. Anexina } 5 \text { é } \\
\text { uma fosfolipase A2 e proteína quinase C de proteína } \\
\text { com atividade inibidora do canal de cálcio e um } \\
\text { potencial papel na transdução de sinal celular, } \\
\text { inflamação, crescimento e diferenciação. Anexina } 5 \\
\text { também tem sido descrito como proteína } \\
\text { anticoagulante. }\end{array}$ \\
\hline Csf2 & $\begin{array}{l}\text { Fator estimulador de colônia } \\
\text { de macrófagos e } \\
\text { granulócitos } 2\end{array}$ & $\begin{array}{l}\text { Fator de } \\
\text { crescimento e } \\
\text { diferenciação } \\
\text { celular }\end{array}$ & $\begin{array}{l}\text { A proteína codificada por este gene é uma citocina } \\
\text { que controla a produção, a diferenciação e a função } \\
\text { dos granulócitos e macrófagos. A forma ativa da } \\
\text { proteína é encontrada no meio extracelular, como um } \\
\text { homodímero. Este gene foi localizado a um grupo de } \\
\text { genes relacionados a região do cromossoma } 5 q 31, \text { o } \\
\text { que é conhecido por estar associado com supressões } \\
\text { intersticiais do } 5 q-\text {-syndrome e leucemia mielóide } \\
\text { aguda. }\end{array}$ \\
\hline Csf3 & $\begin{array}{c}\text { Fator estimulador de colônia } \\
\text { de granulócitos } 3\end{array}$ & $\begin{array}{l}\text { Fator de } \\
\text { crescimento e } \\
\text { diferenciação } \\
\text { celular }\end{array}$ & $\begin{array}{c}\text { A proteína codificada por este gene é uma citocina } \\
\text { que controla a produção, a diferenciação e a função } \\
\text { dos granulócitos. A proteína ativa é encontrada } \\
\text { extracelular. }\end{array}$ \\
\hline Egf & $\begin{array}{l}\text { Fator de crescimento } \\
\text { epidermal }\end{array}$ & $\begin{array}{l}\text { Fator de } \\
\text { crescimento e } \\
\text { diferenciação } \\
\text { celular }\end{array}$ & $\begin{array}{l}\text { Este gene codifica um membro da superfamília do } \\
\text { fator de crescimento epidérmico. A proteína } \\
\text { codificada, é sintetizada como um grande molécula } \\
\text { precursora, que é clivada proteoliticamente para gerar } \\
\text { o fator de crescimento epidérmico de } 53 \text { aminoácidos. } \\
\text { Esta proteína atua como um fator mitogênico potente } \\
\text { que desempenha um papel importante no } \\
\text { crescimento, na proliferação e diferenciação de vários } \\
\text { tipos de células. Esta proteína atua através da ligação } \\
\text { a receptores de superfície celular de afinidade } \\
\text { elevada, o receptor do fator de crescimento } \\
\text { epidérmico. Os defeitos neste gene são a causa de } \\
\text { hipomagnesemia tipo } 4 \text {. A desregulação deste gene } \\
\text { tem sido associado com o crescimento e a progressão } \\
\text { de determinados cânceres. }\end{array}$ \\
\hline
\end{tabular}




\begin{tabular}{|c|c|c|c|}
\hline Fgf1 & $\begin{array}{l}\text { Fator de crescimento de } \\
\text { fibroblastos } 1\end{array}$ & $\begin{array}{l}\text { Fator de } \\
\text { crescimento e } \\
\text { diferenciação } \\
\text { celular }\end{array}$ & $\begin{array}{l}\text { A proteína codificada por esse gene é um membro do } \\
\text { fator de crescimento de fibroblastos (FGF). Membros } \\
\text { da família do FGF possuem ampla atividade } \\
\text { mitogênica e de sobrevivência celular, e estão } \\
\text { envolvidos numa variedade de processos biológicos, } \\
\text { incluindo o desenvolvimento embrionário, o } \\
\text { crescimento celular, a morfogênese, reparação de } \\
\text { tecidos, crescimento de tumores e invasão. Esta } \\
\text { proteína funciona como um modificador da migração } \\
\text { e proliferação de células endoteliais, bem como um } \\
\text { fator angiogênico. Atua como um mitógeno para uma } \\
\text { variedade de células derivadas de mesoderme e } \\
\text { neuroectoderme in vitro. }\end{array}$ \\
\hline Fgf2 & $\begin{array}{l}\text { Fator de crescimento de } \\
\quad \text { fibroblastos } 2\end{array}$ & $\begin{array}{l}\text { Fator de } \\
\text { crescimento e } \\
\text { diferenciação } \\
\text { celular }\end{array}$ & $\begin{array}{l}\text { A proteína codificada por esse gene é um membro do } \\
\text { fator de crescimento de fibroblastos (FGF). Membros } \\
\text { da família FGF ligam a heparina e possuem atividades } \\
\text { mitogênica e angiogênica amplos. Esta proteína tem } \\
\text { sido implicada em processos biológicos diversos, tais } \\
\text { como desenvolvimento do sistema nervoso, } \\
\text { cicatrização de feridas, e crescimento tumoral. }\end{array}$ \\
\hline Fgf3 & $\begin{array}{l}\text { Fator de crescimento de } \\
\quad \text { fibroblastos } 3\end{array}$ & $\begin{array}{l}\text { Fator de } \\
\text { crescimento e } \\
\text { diferenciação } \\
\text { celular }\end{array}$ & $\begin{array}{l}\text { A proteína codificada por esse gene é um membro do } \\
\text { fator de crescimento de fibroblastos (FGF). Membros } \\
\text { da família do FGF possuem ampla atividade } \\
\text { mitogênica e de sobrevivência celular, e estão } \\
\text { envolvidos numa variedade de processos biológicos, } \\
\text { incluindo o desenvolvimento embrionário, o } \\
\text { crescimento celular, a morfogênese, reparação de } \\
\text { tecidos, crescimento de tumores e invasão. }\end{array}$ \\
\hline Fgfr1 & $\begin{array}{l}\text { Receptor para fator de } \\
\text { crescimento de fibroblastos } 1\end{array}$ & $\begin{array}{l}\text { Fator de } \\
\text { crescimento e } \\
\text { diferenciação } \\
\text { celular }\end{array}$ & $\begin{array}{l}\text { A porção extracelular da proteína interage com } \\
\text { fatores de crescimento de fibroblastos, } \\
\text { desencadeando uma cascata de sinais, influenciando } \\
\text { a mitogênese e a diferenciação celular. }\end{array}$ \\
\hline Fgfr2 & $\begin{array}{c}\text { Receptor para fator de } \\
\text { crescimento de fibroblastos } 2\end{array}$ & $\begin{array}{l}\text { Fator de } \\
\text { crescimento e } \\
\text { diferenciação } \\
\text { celular }\end{array}$ & $\begin{array}{l}\text { A porção extracelular da proteína interage com } \\
\text { fatores de crescimento de fibroblastos, } \\
\text { desencadeando uma cascata de sinais, influenciando } \\
\text { a mitogênese e a diferenciação celular. }\end{array}$ \\
\hline Flt1 & $\begin{array}{l}\text { Receptor para fator de } \\
\text { crescimento vascular } \\
\text { endotelial } 1\end{array}$ & $\begin{array}{l}\text { Fator de } \\
\text { crescimento e } \\
\text { diferenciação } \\
\text { celular }\end{array}$ & $\begin{array}{l}\text { Este gene codifica um membro do receptor do fator } \\
\text { (VEGF), a família de crescimento vascular endotelial. } \\
\text { Esta proteína liga-se ao VEGF-A, VEGF-B e fator de } \\
\text { crescimento da placenta, e desempenha um papel } \\
\text { importante na angiogénese e vasculogénese. }\end{array}$ \\
\hline Igf1 & $\begin{array}{l}\text { Fator de crescimento } \\
\text { semelhante à insulina } 1\end{array}$ & $\begin{array}{l}\text { Fator de } \\
\text { crescimento e } \\
\text { diferenciação } \\
\text { celular }\end{array}$ & $\begin{array}{l}\text { A proteína codificada por este gene é semelhante à } \\
\text { insulina em função e estrutura e é um membro de } \\
\text { uma família de proteínas envolvidas na mediação do } \\
\text { crescimento e do desenvolvimento. }\end{array}$ \\
\hline Igf1r & $\begin{array}{l}\text { Receptor para o fator de } \\
\text { crescimento semelhante à } \\
\text { insulina } 1\end{array}$ & $\begin{array}{l}\text { Fator de } \\
\text { crescimento e } \\
\text { diferenciação } \\
\text { celular }\end{array}$ & $\begin{array}{l}\text { O receptor do fator de crescimento é semelhante à } \\
\text { insulina e desempenha um papel crítico em eventos } \\
\text { de transformação. Ele é altamente expresso na } \\
\text { maioria dos tecidos malignos, onde funciona como um } \\
\text { agente anti-apoptóticos, aumentando a sobrevivência } \\
\text { das células. }\end{array}$ \\
\hline
\end{tabular}




\begin{tabular}{|c|c|c|c|}
\hline Pdgfa & $\begin{array}{l}\text { Fator de crescimento } \\
\text { derivado de plaquetas, alfa }\end{array}$ & $\begin{array}{l}\text { Fator de } \\
\text { crescimento e } \\
\text { diferenciação } \\
\text { celular }\end{array}$ & $\begin{array}{c}\text { A proteína codificada por esse gene é um membro da } \\
\text { família do fator de crescimento derivado das } \\
\text { plaquetas. Estudos utilizando camundongos knockout } \\
\text { têm demonstrado defeitos celulares em } \\
\text { oligodendrócitos, células musculares lisas e células } \\
\text { alveolares. }\end{array}$ \\
\hline$V d r$ & Receptor para vitamina $\mathrm{D}$ & $\begin{array}{l}\text { Fator de } \\
\text { crescimento e } \\
\text { diferenciação } \\
\text { celular }\end{array}$ & $\begin{array}{c}\text { Este gene codifica o receptor da vitamina D3. Este } \\
\text { receptor também funciona como um receptor para o } \\
\text { ácido biliar. O receptor pertence à família de fatores } \\
\text { reguladores da transcrição e mostra similaridade de } \\
\text { sequência com os receptores de hormônios esteróides } \\
\text { e da tireóide. }\end{array}$ \\
\hline Vegfa & $\begin{array}{l}\text { Fator de crescimento } \\
\text { endotelial vascular } A\end{array}$ & $\begin{array}{l}\text { Fator de } \\
\text { crescimento e } \\
\text { diferenciação } \\
\text { celular }\end{array}$ & $\begin{array}{c}\text { Codifica uma proteína que atua especificamente sobre } \\
\text { as células endoteliais e tem vários efeitos, incluindo a } \\
\text { mediação de aumento da permeabilidade vascular, } \\
\text { induzindo a proliferação celular a angiogênese, a } \\
\text { vasculogênese, promovendo a migração de células e } \\
\text { inibição da apoptose. }\end{array}$ \\
\hline Vegfb & $\begin{array}{l}\text { Fator de crescimento } \\
\text { endotelial vascular B }\end{array}$ & $\begin{array}{l}\text { Fator de } \\
\text { crescimento e } \\
\text { diferenciação } \\
\text { celular }\end{array}$ & $\begin{array}{c}\text { Este gene codifica um membro da PDGF (fator de } \\
\text { crescimento derivado de plaquetas) / VEGF (fator de } \\
\text { crescimento endotelial vascular) familiar. Os membros } \\
\text { da família VEGF regulam a formação de vasos } \\
\text { sanguíneos e estão envolvidos na função da célula } \\
\text { endotelial. }\end{array}$ \\
\hline Colla1 & Colágeno, tipo I, alfa I & $\begin{array}{l}\text { Proteínas da matriz } \\
\text { extracelular - } \\
\text { Colagênicas }\end{array}$ & $\begin{array}{l}\text { Este gene codifica as cadeias pró-alfa1 de colágeno } \\
\text { tipo I. O tipo I é um formador de fibrila de colágenio } \\
\text { encontrada na maioria dos tecidos conjuntivos e é } \\
\text { abundante no osso, córnea, derme e tendão. } \\
\text { Mutações nesse gene estão associadas com } \\
\text { osteogênese imperfeita tipos I-IV, de Ehlers-Danlos } \\
\text { tipo VIIA, Ehlers-Danlos tipo Clássica, Caffey Doenças } \\
\text { e osteoporose idiopática. }\end{array}$ \\
\hline Colla2 & Colágeno, tipo I, alfa II & $\begin{array}{l}\text { Proteínas da matriz } \\
\text { extracelular - } \\
\text { Colagênicas }\end{array}$ & $\begin{array}{l}\text { Os sintomas associados com mutações neste gene, } \\
\text { tendem a ser menos graves do que as mutações no } \\
\text { gene para a cadeia alfa } 1 \text { de colágeno tipo I } \\
\text { (COL1A1), refletindo os diferentes papéis de alfa2 na } \\
\text { integridade da matriz. }\end{array}$ \\
\hline Col2a1 & Colágeno, tipo II, alfa I & $\begin{array}{l}\text { Proteínas da matriz } \\
\text { extracelular - } \\
\text { Colagênicas }\end{array}$ & $\begin{array}{l}\text { Este gene codifica a cadeia de alfa-1 de colágeno do } \\
\text { tipo II, um colagénio fibrilar encontrados na } \\
\text { cartilagem e no vítreo do olho. }\end{array}$ \\
\hline Col3a1 & Colágeno, tipo III, alfa I & $\begin{array}{l}\text { Proteínas da matriz } \\
\text { extracelular - } \\
\text { Colagênicas }\end{array}$ & $\begin{array}{l}\text { Este gene codifica para as cadeias de alfa1 pró- } \\
\text { colágeno de tipo III, um colágeno fibrilar que é } \\
\text { encontrado nos tecidos conjuntivos extensíveis, tais } \\
\text { como pele, pulmão, útero, intestino delgado e do } \\
\text { sistema vascular, frequentemente em associação com } \\
\text { o colagénio do tipo I. Mutações nesse gene estão } \\
\text { associadas com síndrome de Ehlers-Danlos tipo IV e } \\
\text { com aneurismas da aorta e arterial. }\end{array}$ \\
\hline Col4a1 & Colágeno, tipo IV, alfa I & $\begin{array}{l}\text { Proteínas da matriz } \\
\text { extracelular - } \\
\text { Colagênicas }\end{array}$ & $\begin{array}{l}\text { Este gene codifica o tipo IV da cadeia alfa de } \\
\text { colágeno das membranas basais. }\end{array}$ \\
\hline
\end{tabular}




\begin{tabular}{|c|c|c|c|}
\hline Col4a2 & Colágeno, tipo IV, alfa II & $\begin{array}{l}\text { Proteínas da matriz } \\
\text { extracelular - } \\
\text { Colagênicas }\end{array}$ & $\begin{array}{l}\text { Este gene codifica uma das seis subunidades do } \\
\text { colágeno tipo IV, o principal componente estrutural } \\
\text { das membranas basais. A porção C-terminal da } \\
\text { proteína, conhecida como canstatin, é um inibidor da } \\
\text { angiogênese e o crescimento tumoral. }\end{array}$ \\
\hline Col5a1 & Colágeno, tipo V, alfa I & $\begin{array}{l}\text { Proteínas da matriz } \\
\text { extracelular - } \\
\text { Colagênicas }\end{array}$ & $\begin{array}{c}\text { Colágeno tipo V é encontrada em tecidos contendo } \\
\text { colágeno tipo I e parece regular o conjunto de fibras } \\
\text { heterotípicos compostas de colágenos dos tipos I e V. } \\
\text { O produto desse gene está intimamente relacionado } \\
\text { com o tipo de colágeno XI e é possível que as cadeias } \\
\text { de colágeno dos tipos V e XI constituem um tipo } \\
\text { único de colágeno com combinações de cadeias } \\
\text { específicas de tecido. }\end{array}$ \\
\hline Col6a1 & Colágeno, tipo VI, alfa I & $\begin{array}{l}\text { Proteínas da matriz } \\
\text { extracelular - } \\
\text { Colagênicas }\end{array}$ & $\begin{array}{l}\text { Os colágenos são uma super família de proteínas que } \\
\text { desempenham um papel importante na manutenção } \\
\text { da integridade dos vários tecidos. Colágeno VI é um } \\
\text { componente estrutural principal das microfibrilas. }\end{array}$ \\
\hline Col6a2 & Colágeno, tipo VI, alfa II & $\begin{array}{l}\text { Proteínas da matriz } \\
\text { extracelular - } \\
\text { Colagênicas }\end{array}$ & $\begin{array}{l}\text { Este gene codifica uma das três cadeias de colágeno } \\
\text { tipo VI, um filamento encontrado na maioria dos } \\
\text { tecidos conjuntivos. Mutações neste gene estão } \\
\text { associadas a miopatia de Bethlem e distrofia } \\
\text { muscular. Três variantes de transcrição foram } \\
\text { identificados para este gene. }\end{array}$ \\
\hline Col7a1 & Colágeno, tipo VII, alfa I & $\begin{array}{l}\text { Proteínas da matriz } \\
\text { extracelular - } \\
\text { Colagênicas }\end{array}$ & $\begin{array}{l}\text { Funciona como um fibrilas de ancoragem entre os } \\
\text { epitélios externo e o estroma subjacente. Mutações } \\
\text { nesse gene estão associadas com todas as formas de } \\
\text { epidermólise bolhosa distrófica. }\end{array}$ \\
\hline Col10a1 & Colágeno, tipo X, alfa I & $\begin{array}{l}\text { Proteínas da matriz } \\
\text { extracelular - } \\
\text { Colagênicas }\end{array}$ & $\begin{array}{l}\text { Este gene codifica a cadeia alfa do tipo X, uma cadeia } \\
\text { curta expressa por condrócitos hipertróficos durante a } \\
\text { ossificação endocondral. }\end{array}$ \\
\hline Col11a1 & Colágeno, tipo XI, alfa I & $\begin{array}{l}\text { Proteínas da matriz } \\
\text { extracelular - } \\
\text { Colagênicas }\end{array}$ & $\begin{array}{l}\text { Múltiplas variantes de transcrição foram identificados } \\
\text { para este gene. Este gene codifica para uma das duas } \\
\text { cadeias alfa de colágeno do tipo XI, um colágeno } \\
\text { fibrilar menor. Mutações neste gene estão associadas } \\
\text { a síndrome de Stickler tipo II e com a síndrome de } \\
\text { Marshall. }\end{array}$ \\
\hline Col12a1 & Colágeno, tipo XI, alfa I & $\begin{array}{l}\text { Proteínas da matriz } \\
\text { extracelular - } \\
\text { Colagênicas }\end{array}$ & $\begin{array}{l}\text { Este gene codifica para a cadeia alfa de colágeno do } \\
\text { tipo XII, um membro da família de colágeno FACIT } \\
\text { (colágenos associados a fibrilas com hélice tripla } \\
\text { interrompida). Tipo XII colágeno é uma homotrímero } \\
\text { encontrado em associação com colágeno tipo I, uma } \\
\text { associação para modificar as interações entre as } \\
\text { fibrilas de colágeno I e a matriz circundante. }\end{array}$ \\
\hline Col14a1 & Colágeno, tipo XIV, alfa I & $\begin{array}{l}\text { Proteínas da matriz } \\
\text { extracelular - } \\
\text { Colagênicas }\end{array}$ & $\begin{array}{l}\text { Este gene codifica para a cadeia alfa de colágeno do } \\
\text { tipo XIV, um membro da família FACIT (colágenos } \\
\text { associados a fibrilas com hélice tripla interrompida). } \\
\text { Tipo XIV colágeno interage com a superfície de } \\
\text { fibrilas e está envolvido na regulação de fibrilogênese. }\end{array}$ \\
\hline
\end{tabular}




\begin{tabular}{|c|c|c|c|}
\hline Ahsg & Alfa-2-HS-Glicoproteína & $\begin{array}{l}\text { Proteínas da matriz } \\
\text { extracelular - Não } \\
\text { colagênicas }\end{array}$ & $\begin{array}{c}\text { Glicoproteina a2-HS (AHSG), é uma glicoproteína } \\
\text { presente no soro, sintetizada pelos hepatócitos. Ela } \\
\text { está envolvida em várias funções, tais como a } \\
\text { endocitose, o desenvolvimento do cérebro e da } \\
\text { formação de tecido ósseo. A proteína é geralmente } \\
\text { presente na placa cortical do córtex cerebral e na } \\
\text { medula óssea imatura, participa no desenvolvimento } \\
\text { dos tecidos. No entanto, o seu significado exato ainda } \\
\text { é desconhecido. }\end{array}$ \\
\hline$A / p /$ & Fosfatase alcalina & $\begin{array}{l}\text { Proteínas da matriz } \\
\text { extracelular - Não } \\
\text { colagênicas }\end{array}$ & $\begin{array}{l}\text { Há pelo menos quatro distintas, porém relacionadas: } \\
\text { fosfatase alcalina intestinal, placenta, placenta-like, e } \\
\text { fígado / osso / rim (tecido não-específico). Os } \\
\text { primeiros três estão localizados no cromossomo 2, } \\
\text { enquanto que a forma não específica do tecido está } \\
\text { localizado no cromossomo } 1 \text {. O produto deste gene é } \\
\text { uma enzima ligada à membrana glicosilada que não é } \\
\text { expressa em qualquer tecido particular e é, por } \\
\text { conseguinte, referida como a forma de tecido não- } \\
\text { específica da enzima. A função fisiológica exata das } \\
\text { fosfatases alcalinas não é conhecido. Uma função } \\
\text { proposta deste tipo de enzima é a mineralização da } \\
\text { matriz. Este enzima tem sido associada diretamente a } \\
\text { hipofosfatasia, uma doença que é caracterizada por } \\
\text { hipercalcemia e inclui defeitos esqueléticos. O caráter } \\
\text { deste distúrbio pode variar, contudo, dependendo da } \\
\text { mutação específica, uma vez que esta determina a } \\
\text { idade do seu aparecimento e gravidade dos sintomas. }\end{array}$ \\
\hline$A m b n$ & Ameloblastina & $\begin{array}{l}\text { Proteínas da matriz } \\
\text { extracelular - Não } \\
\text { colagênicas }\end{array}$ & $\begin{array}{c}\text { Este gene codifica a proteína da matriz do esmalte. A } \\
\text { proteína codificada pode ser importante para a } \\
\text { formação da matriz do esmalte e mineralização. } \\
\text { Mutações neste gene podem ser associadas com } \\
\text { dentinogênese imperfeita e amelogênese imperfeita } \\
\text { autossômica dominante. }\end{array}$ \\
\hline Bgn & Biglicano & $\begin{array}{l}\text { Proteínas da matriz } \\
\text { extracelular - Não } \\
\text { colagênicas }\end{array}$ & $\begin{array}{c}\text { Esta proteína desempenha um papel na montagem de } \\
\text { fibrilas de colágeno e regeneração muscular. Interage } \\
\text { com várias proteínas envolvidas na distrofia muscular, } \\
\text { incluindo o alfa-distroglicana, alfa-e gama- } \\
\text { sarcoglicanos e colágeno VI. }\end{array}$ \\
\hline Ctsk & Catepsina K & $\begin{array}{l}\text { Proteínas da matriz } \\
\text { extracelular - Não } \\
\text { colagênicas }\end{array}$ & $\begin{array}{c}\text { A proteína codificada por este gene é uma protease } \\
\text { de cisteína lisossômica, envolvida na remodelação do } \\
\text { osso e reabsorção. Esta proteína, que é um membro } \\
\text { da família de proteínas de peptidase C1, é } \\
\text { predominantemente expressa em osteoclastos. No } \\
\text { entanto, a proteína codificada é também expressa } \\
\text { numa fração significativa de cânceres da mama } \\
\text { humanos, onde se poderia contribuir para a } \\
\text { capacidade de invasão tumoral. Mutações nesse gene } \\
\text { são a causa de pycnodysostosis, uma doença } \\
\text { autossômica recessiva, caracterizada por } \\
\text { osteosclerose e baixa estatura. }\end{array}$ \\
\hline Dmp1 & $\begin{array}{l}\text { Proteína da matriz dentinária } \\
1\end{array}$ & $\begin{array}{l}\text { Proteínas da matriz } \\
\text { extracelular - Não } \\
\text { colagênicas }\end{array}$ & $\begin{array}{c}\text { É uma proteína da matriz extracelular. Esta proteína é } \\
\text { crítica para a boa mineralização do osso e dentina, } \\
\text { está presente em diversas células de osso e dos } \\
\text { tecidos dentais. Em osteoblastos indiferenciados é } \\
\text { uma proteína nuclear que regula a expressão de } \\
\text { genes específicos dos osteoblastos. Durante a } \\
\text { maturação dos osteoblastos, a proteína se torna } \\
\text { fosforilada e é exportada para a matriz extracelular, } \\
\text { onde ela orquestra a formação da matriz } \\
\text { mineralizada. Mutações no gene são conhecidas por } \\
\text { causar hipofosfatemia autossômica recessiva, uma } \\
\text { doença que se manifesta como raquitismo e } \\
\text { osteomalácia. }\end{array}$ \\
\hline
\end{tabular}




\begin{tabular}{|c|c|c|c|}
\hline Mmp2 & Metalopeptidase da matriz 2 & $\begin{array}{l}\text { Proteínas da matriz } \\
\text { extracelular - Não } \\
\text { colagênicas }\end{array}$ & $\begin{array}{l}\text { As proteínas da metaloproteinase (MMP) da matriz da } \\
\text { família estão envolvidas na quebra da matriz } \\
\text { extracelular em processos fisiológicos normais, tais } \\
\text { como desenvolvimento embrionário, reprodução e } \\
\text { remodelagem tecidual, bem como em processos de } \\
\text { doença, tais como artrite e metástases. Este gene } \\
\text { codifica uma enzima que degrada o colágeno tipo IV, } \\
\text { o principal componente estrutural das membranas } \\
\text { basais. A enzima desempenha um papel importante } \\
\text { na desagregação menstrual do endométrio, na } \\
\text { regulação da vascularização e na resposta } \\
\text { inflamatória. }\end{array}$ \\
\hline Mmp8 & Metalopeptidase da matriz 8 & $\begin{array}{l}\text { Proteínas da matriz } \\
\text { extracelular - Não } \\
\text { colagênicas }\end{array}$ & $\begin{array}{l}\text { Sua função é a degradação do colágenos tipo I, II e } \\
\text { II. O gene faz parte de um grupo de genes de MMP } \\
\text { que se localizam no cromossomo } 11 q 22.3 \text {. }\end{array}$ \\
\hline Mmp9 & Metalopeptidase da matriz 9 & $\begin{array}{l}\text { Proteínas da matriz } \\
\text { extracelular - Não } \\
\text { colagênicas }\end{array}$ & $\begin{array}{l}\text { A enzima codificada por este gene degrada colágeno } \\
\text { tipo IV e V. Os estudos em macacos rhesus sugerem } \\
\text { que a enzima está envolvida na mobilização de IL-8, } \\
\text { induzida por células progenitoras hematopoiéticas da } \\
\text { medula óssea. Estudos em murinos sugerem um } \\
\text { papel na remodelação do tecido associado a tumor. }\end{array}$ \\
\hline Mmp10 & $\begin{array}{l}\text { Metalopeptidase da matriz } \\
\qquad 10\end{array}$ & $\begin{array}{l}\text { Proteínas da matriz } \\
\text { extracelular - Não } \\
\text { colagênicas }\end{array}$ & $\begin{array}{c}\text { A enzima codificada por este gene degrada } \\
\text { proteoglicanos e fibronectina. O gene faz parte de um } \\
\text { grupo de genes de MMP que localizam no } \\
\text { cromossoma 11q22.3. }\end{array}$ \\
\hline Phex & $\begin{array}{l}\text { Endopeptidase regudora de } \\
\text { fosfato, PHEX }\end{array}$ & $\begin{array}{l}\text { Proteínas da matriz } \\
\text { extracelular - Não } \\
\text { colagênicas }\end{array}$ & $\begin{array}{l}\text { A proteína codificada por este gene é uma } \\
\text { endopeptidase transmembranar que pertence à } \\
\text { família II da membrana de endopeptidase, } \\
\text { dependente de zinco. }\end{array}$ \\
\hline Serpinh1 & $\begin{array}{c}\text { Inibidor de peptidase } \\
\text { serínica, classe } \mathrm{H} \text {, membro1 }\end{array}$ & $\begin{array}{l}\text { Proteínas da matriz } \\
\text { extracelular - Não } \\
\text { colagênicas }\end{array}$ & $\begin{array}{l}\text { Este gene codifica um membro da superfamília das } \\
\text { serpinas, dos inibidores de proteases de serina. A } \\
\text { proteína codificada está localizada no retículo } \\
\text { endoplasmático e desempenha um papel na } \\
\text { biossíntese de colágeno. Anticorpos contra a proteína } \\
\text { codificada foram encontrados em pacientes com } \\
\text { artrite reumatóide. A expressão deste gene pode ser } \\
\text { um marcador para o câncer, e polimorfismos neste } \\
\text { gene podem ser associada ao nascimento prematuro, } \\
\text { causado pela ruptura prematura de membranas. }\end{array}$ \\
\hline Sost & Esclerostina & $\begin{array}{l}\text { Proteínas da matriz } \\
\text { extracelular - Não } \\
\quad \text { colagênicas }\end{array}$ & $\begin{array}{c}\text { É uma glicoproteína semelhante ao DAN, antagonistas } \\
\text { da família de proteína morfogenética óssea (BMP). } \\
\text { Mutações de perda de função deste gene está } \\
\text { associada a uma doença autossômica recessiva, } \\
\text { esclerosteose, o que provoca o crescimento excessivo } \\
\text { do osso progressiva. }\end{array}$ \\
\hline Tfip11 & $\begin{array}{c}\text { Proteína que interagem com } \\
\text { Tuftelina-11 }\end{array}$ & $\begin{array}{l}\text { Proteínas da matriz } \\
\text { extracelular - Não } \\
\text { colagênicas }\end{array}$ & $\begin{array}{l}\text { TFIP11 é uma proteína localizada no núcleo, que } \\
\text { pode desempenhar um papel na desmontagem } \\
\text { cromossômica em corpos de Cajal. }\end{array}$ \\
\hline
\end{tabular}




\begin{tabular}{|c|c|c|c|}
\hline Tuft1 & Tuftelina-1 & $\begin{array}{l}\text { Proteínas da matriz } \\
\text { extracelular - Não } \\
\text { colagênicas }\end{array}$ & $\begin{array}{l}\text { Proteína do esmalte envolvida na mineralização do } \\
\text { esmalte. }\end{array}$ \\
\hline$C d 36$ & CD36 & $\begin{array}{l}\text { Moléculas de } \\
\text { adesão celular }\end{array}$ & $\begin{array}{c}\text { A proteína codificada por este gene é a quarta } \\
\text { principal glicoproteína da superfície das plaquetas, e } \\
\text { serve como um receptor para trombospondina em } \\
\text { plaquetas e em várias linhas celulares. Mutações } \\
\text { neste gene causam a deficiência de plaquetas } \\
\text { glicoproteína. Há várias variantes transcritos que } \\
\text { codificam a mesma proteína, encontrada para este } \\
\text { gene. }\end{array}$ \\
\hline Cdh11 & Caderina 11 & $\begin{array}{l}\text { Moléculas de } \\
\text { adesão celular }\end{array}$ & $\begin{array}{l}\text { A expressão desta proteína em linhas celulares de } \\
\text { osteoblastos, durante a diferenciação, sugere uma } \\
\text { função específica no desenvolvimento e manutenção } \\
\text { do osso. }\end{array}$ \\
\hline Comp & $\begin{array}{l}\text { Proteína oligomérica da } \\
\text { matriz cartilaginosa }\end{array}$ & $\begin{array}{l}\text { Moléculas de } \\
\text { adesão celular }\end{array}$ & $\begin{array}{l}\text { A proteína codificada por este gene é uma proteínas } \\
\text { extracelulares não colagênica. }\end{array}$ \\
\hline$F n 1$ & Fibronectina-1 & $\begin{array}{l}\text { Moléculas de } \\
\text { adesão celular }\end{array}$ & $\begin{array}{c}\text { Este gene codifica a fibronectina, que está envolvida } \\
\text { na adesão celular e os processos de migração, } \\
\text { incluindo embriogênese, cicatrização de feridas, a } \\
\text { coagulação do sangue, defesa do hospedeiro e } \\
\text { metástase. }\end{array}$ \\
\hline Icam1 & $\begin{array}{l}\text { Molécula de adesão } \\
\text { intercelular-1 }\end{array}$ & $\begin{array}{l}\text { Moléculas de } \\
\text { adesão celular }\end{array}$ & $\begin{array}{l}\text { Este gene codifica uma glicoproteína de superfície } \\
\text { celular, que é normalmente expressa em células } \\
\text { endoteliais e células do sistema imune. Ele liga-se a } \\
\text { integrinas do tipo CD11a / CD18, CD11b ou / CD18 e } \\
\text { também é utilizado pelo rinovírus como um receptor. }\end{array}$ \\
\hline $\operatorname{Itga2}$ & Integrina alfa-2 & $\begin{array}{l}\text { Moléculas de } \\
\text { adesão celular }\end{array}$ & $\begin{array}{l}\text { Este gene codifica a subunidade alfa de um receptor } \\
\text { transmembranar de colágeno e proteínas } \\
\text { relacionadas. A proteína codificada forma um } \\
\text { heterodímero com uma subunidade beta e medeia a } \\
\text { adesão das plaquetas e outros tipos de células à } \\
\text { matriz extracelular. Perda da proteína codificada está } \\
\text { associada com a desordem de plaquetas. }\end{array}$ \\
\hline Itga $2 b$ & Integrina alfa-2B & $\begin{array}{l}\text { Moléculas de } \\
\text { adesão celular }\end{array}$ & $\begin{array}{l}\text { As integrinas são proteínas integrais de membrana } \\
\text { heterodiméricas constituídos por uma cadeia alfa e } \\
\text { uma cadeia beta, para formar um receptor de } \\
\text { fibronectina expressa em plaquetas, que desempenha } \\
\text { um papel crucial na coagulação. }\end{array}$ \\
\hline Itga3 & Integrina alfa-3 & $\begin{array}{l}\text { Moléculas de } \\
\text { adesão celular }\end{array}$ & $\begin{array}{l}\text { A proteína codificada por este gene forma uma } \\
\text { integrina que interage com muitas proteínas de matriz } \\
\text { extracelular. Variantes de splicing alternativo de } \\
\text { transcritos que codificam diferentes isoformas foram } \\
\text { identificados para este gene. }\end{array}$ \\
\hline
\end{tabular}




\begin{tabular}{|c|c|c|c|}
\hline Itgam & Integrina alfa-M & $\begin{array}{l}\text { Moléculas de } \\
\text { adesão celular }\end{array}$ & $\begin{array}{l}\text { É importante na aderência de neutrófilos e monócitos } \\
\text { ao endotélio estimulado, e também na fagocitose de } \\
\text { partículas revestidas do complemento. Várias } \\
\text { variantes de transcritos que codificam diferentes } \\
\text { isoformas foram encontradas por este gene. }\end{array}$ \\
\hline Itgav & Integrina alfa-V & $\begin{array}{l}\text { Moléculas de } \\
\text { adesão celular }\end{array}$ & $\begin{array}{l}\text { ITAGV codifica a cadeia de integrina alfa V. Além de } \\
\text { aderência, são conhecidas muitas integrinas para } \\
\text { facilitar a transdução de sinal. }\end{array}$ \\
\hline Itgb1 & $\begin{array}{l}\text { Integrina beta-1 (receptor } \\
\text { para fibronectina) }\end{array}$ & $\begin{array}{l}\text { Moléculas de } \\
\text { adesão celular }\end{array}$ & $\begin{array}{l}\text { As integrinas são proteínas heterodiméricos } \\
\text { compostas de subunidades alfa e beta. Pelo menos } 18 \\
\text { alfa e oito subunidades beta foram descritos em } \\
\text { mamíferos. Membros da família das integrinas são } \\
\text { receptores de membrana envolvidos na adesão } \\
\text { celular e reconhecimento de uma variedade de } \\
\text { processos, incluindo embriogénese, hemostasia, } \\
\text { reparação de tecidos, resposta imune e difusão } \\
\text { metastática de células tumorais. Este gene codifica } \\
\text { uma subunidade beta. } \\
\end{array}$ \\
\hline Scarb1 & $\begin{array}{l}\text { Receptor Scavenger, classe } \\
\text { B, tipo I }\end{array}$ & $\begin{array}{l}\text { Moléculas de } \\
\text { adesão celular }\end{array}$ & $\begin{array}{c}\text { A proteína codificada por este gene é um receptor de } \\
\text { membrana de plasma de colesterol de lipoproteína de } \\
\text { alta densidade (HDL). A proteína codificada medeia a } \\
\text { transferência de colesterol para HDL. Além disso, esta } \\
\text { proteína é um receptor para o vírus da hepatite C } \\
\text { glicoproteína E2. }\end{array}$ \\
\hline Vcam1 & $\begin{array}{l}\text { Molécula de adesão celular } \\
\text { vascular-1 }\end{array}$ & $\begin{array}{l}\text { Moléculas de } \\
\text { adesão celular }\end{array}$ & $\begin{array}{l}\text { Este gene é um membro da superfamília das } \\
\text { imunoglobulinas e codifica uma sialoglicoproteína na } \\
\text { superfície celular expressa pelo endotélio ativado por } \\
\text { citocinas. Este tipo I medeia a adesão das células, na } \\
\text { transdução de sinais, e pode desempenhar um papel } \\
\text { no desenvolvimento da aterosclerose e da artrite } \\
\text { reumatóide. }\end{array}$ \\
\hline Ms $\times 1$ & Osterix & $\begin{array}{l}\text { Fatores de } \\
\text { transcrição }\end{array}$ & $\begin{array}{l}\text { Também podem ter um papel na formação do padrão } \\
\text { de membros, desenvolvimento craniofacial, } \\
\text { particularmente odontogênese, e inibição do } \\
\text { crescimento do tumor. Mutações nesse gene têm sido } \\
\text { associadas com não sindrômica lábio leporino com ou } \\
\text { sem fenda palatina. As funções das proteínas } \\
\text { codificadas durante a embriogénese ocorre através da } \\
\text { interacção com os componentes do complexo de } \\
\text { transcrição e outras homeoproteínas do núcleo. }\end{array}$ \\
\hline$N f k b 1$ & $\begin{array}{l}\text { Fator de transcrição nuclear } \\
\text { kappa B, p105 }\end{array}$ & $\begin{array}{l}\text { Fatores de } \\
\text { transcrição }\end{array}$ & $\begin{array}{l}\text { Este gene codifica uma proteína de } 105 \text { kDa. A } \\
\text { proteína de } 105 \text { kDa é um inibidor específico da } \\
\text { transcrição de proteínas Rep e a proteína de } 50 \text { kDa é } \\
\text { um ADN da subunidade de ligação da (NFKB) } \\
\text { complexo de proteína de NF-kappa-B. NFKB é um } \\
\text { regulador de transcrição que é ativado por vários } \\
\text { estímulos intra-e extra-celulares, tais como as } \\
\text { citocinas, os radicais livres oxidantes, irradiação } \\
\text { ultravioleta, e produtos bacterianos ou virais. Ativado, } \\
\text { NFkB transloca para o núcleo, e estimula a expressão } \\
\text { de genes envolvidos em uma ampla variedade de } \\
\text { funções biológicas. Ativação inapropriada de NFKB } \\
\text { tem sido associada a um número de doenças } \\
\text { inflamatórias, enquanto que a inibição persistente de } \\
\text { NFKB leva a uma resposta imune inadequada ou } \\
\text { inibição da proliferação celular. }\end{array}$ \\
\hline
\end{tabular}




\begin{tabular}{|c|c|c|c|}
\hline Runx2 & $\begin{array}{l}\text { Fator de transcrição } \\
\text { relacionado ao RUNT-2 }\end{array}$ & $\begin{array}{l}\text { Fatores de } \\
\text { transcrição }\end{array}$ & $\begin{array}{l}\text { Este gene é um membro da família de fatores de } \\
\text { transcrição RUNX e codifica uma proteína nuclear com } \\
\text { um domínio de ligação de ADN Runt. Esta proteína é } \\
\text { essencial para a diferenciação dos osteoblastos e } \\
\text { morfogênese óssea e age como um andaime para os } \\
\text { ácidos nucleicos e os fatores reguladores envolvidos } \\
\text { na expressão do gene do esqueleto. Mutações neste } \\
\text { gene estão associadas com o desenvolvimento ósseo, } \\
\text { a displasia cleidocraniana. }\end{array}$ \\
\hline Smad1 & SMAD1 & $\begin{array}{l}\text { Fatores de } \\
\text { transcrição }\end{array}$ & $\begin{array}{c}\text { Proteínas SMAD são transdutores de sinal e } \\
\text { moduladores da transcrição que medeiam várias vias } \\
\text { de sinalização. Esta proteína medeia os sinais das } \\
\text { proteínas morfogenéticas ósseas (BMPs), que estão } \\
\text { envolvidos numa variedade de atividades biológicas, } \\
\text { incluindo o crescimento celular, a apoptose, a } \\
\text { morfogênese, desenvolvimento e respostas imunes. A } \\
\text { forma fosforilada da proteína forma um complexo } \\
\text { com SMAD4, que é importante para a sua função na } \\
\text { regulação da transcrição. }\end{array}$ \\
\hline Smad2 & SMAD2 & $\begin{array}{l}\text { Fatores de } \\
\text { transcrição }\end{array}$ & $\begin{array}{l}\text { Esta proteína medeia a sinalização do factor de } \\
\text { crescimento transformador (TGF)-beta, e portanto } \\
\text { regula vários processos celulares, tais como a } \\
\text { proliferação celular, a apoptose, e de diferenciação. } \\
\text { Esta proteína é recrutado para os receptores de TGF- } \\
\text { beta, em resposta ao sinal de TGF-beta, esta proteína } \\
\text { é fosforilada por os receptores de TGF-beta. A } \\
\text { fosforilação induz a dissociação da proteína com SARA } \\
\text { e a associação com o SMAD4 membro da família. A } \\
\text { associação com SMAD4 é importante para a } \\
\text { translocação da proteína para o núcleo, onde se liga } \\
\text { ao alvo promotores e forma um complexo repressor } \\
\text { de transcrição com outros co-fatores. }\end{array}$ \\
\hline Smad3 & SMAD3 & $\begin{array}{l}\text { Fatores de } \\
\text { transcrição }\end{array}$ & $\begin{array}{l}\text { Esta proteína funciona como um modulador da } \\
\text { transcrição ativada por fator de crescimento } \\
\text { transformante-beta e desempenha um papel na } \\
\text { regulação da carcinogênese. }\end{array}$ \\
\hline Smad4 & SMAD4 & $\begin{array}{l}\text { Fatores de } \\
\text { transcrição }\end{array}$ & $\begin{array}{l}\text { O produto deste gene forma complexos homoméricos } \\
\text { e complexos heteroméricos com outras proteínas } \\
\text { Smad ativadas, que então se acumulam no núcleo e } \\
\text { regulam a transcrição de genes alvo. }\end{array}$ \\
\hline Sox9 & Fator de transcrição SOX-9 & $\begin{array}{l}\text { Fatores de } \\
\text { transcrição }\end{array}$ & $\begin{array}{c}\text { Age durante a diferenciação de condrócitos e, com } \\
\text { fator esteroidogênica 1, regula a transcrição do gene } \\
\text { para o hormônio anti-Muellerian (AMH). Deficiências } \\
\text { neste, levam à síndrome de malformação esquelética } \\
\text { Displasia Campomélica, frequentemente com reversão } \\
\text { sexual. }\end{array}$ \\
\hline Twist1 & $\begin{array}{c}\text { Fator de transcrição TWIST- } \\
1\end{array}$ & $\begin{array}{l}\text { Fatores de } \\
\text { transcrição }\end{array}$ & $\begin{array}{l}\text { A proteína codificada por este gene é um fator de } \\
\text { transcrição de bHLH e partilha similaridade com outro } \\
\text { fator de transcrição de bHLH, Dermo1. A expressão } \\
\text { forte de RNAm está presente em tecido placentário, } \\
\text { em adultos. Mutações nesse gene foram encontrados } \\
\text { em pacientes com Síndrome de Saethre-Chotzen. }\end{array}$ \\
\hline
\end{tabular}


Anexo 

ANEXo A - Folha de Aprovação do Projeto de Pesquisa Na Comissão de Ética no Uso de Animais (CEUA)

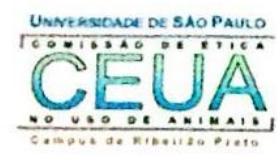

\section{UNIVERSIDADE DE SÃO PAULO Campus de Ribeiräo Preto \\ Comissâo de Ĺticn no Uso de Animnis}

\section{E R T I F I C A D O}

Certificamos que o trabalho (Protocolo 13.1.266.53.6), intitulado "Investigaçâo do papel da enzima ciclooxigenase-2 na reabsorção óssea periapical induzida pelo lipopolissacarideo bacteriano", de autoria de Fernanda Regina Ribeiro Santos o Francisco W G. de Paula e Silva, por estar de acordo com os Princípios Éticos na Experimentação Animal adotado pela Comissão de Ética no Uso de Animais (CEUA) do Campus de Ribeirão Preto - USP foi aprovado em reunião da CEUA de 02/12/2013.

Colaboradores: Lucia Helena Faccioli

Léa Assed Bezerra da Silva

Geyson Galo da Silva

This is to certify that the work (Protocol number 13.1.266.53.6), entitled: "Investigação do papel da enzima ciclooxigenase-2 na reabsorção óssea periapical induzida pelo lipopolissacarideo bacteriano", by Fernanda Regina Ribeiro Santos and Francisco W G. de Paula e Silva is in accordance with the Ethic Principles in Animal Experimentation adopted by Ethic Commission for the Use of Animals (CEUA) of the Campus of Ribeirão Preto - USP, and was approved in an ordinary meeting of CEUA. December, 22013.

Ribeirão Preto, 03 de Dezembro de 2013.

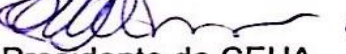

Presidente da CEUA

Profa. Dra. Cláudia Maria Padovan

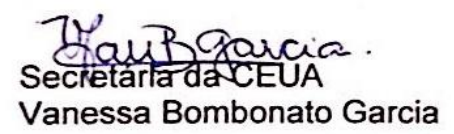

Av. Bandeirantes, 3900 - CEP 14040-900 - Ribeirão Preto - São Paulo Fone: (16) 36023526 - Fax: (16) 36023526 